NYPL RESEARCH LIBAARIES 





DR. JOHN McLOUGHLIN 




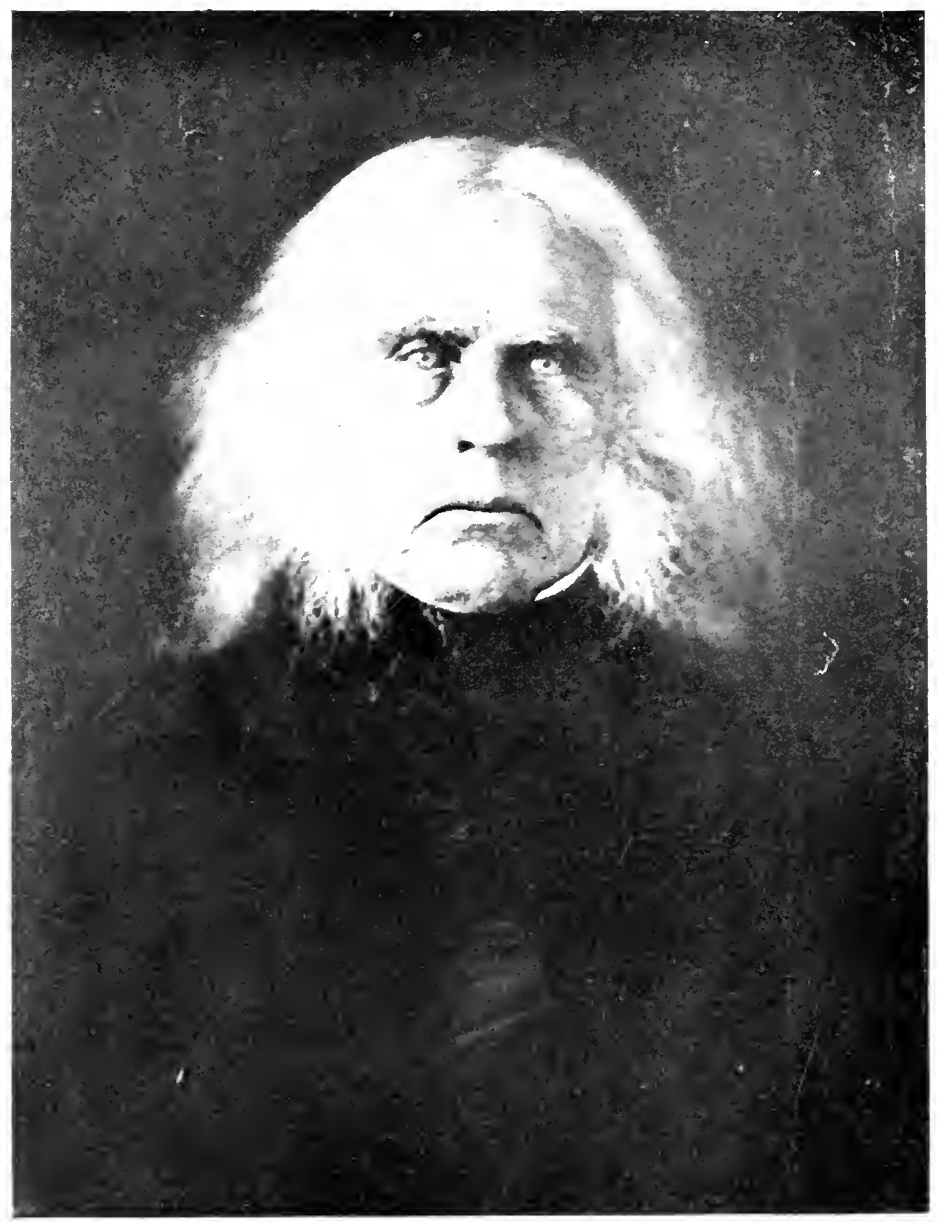

DR. Johx MeLotihlix

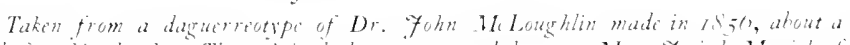

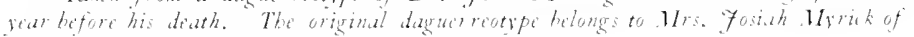

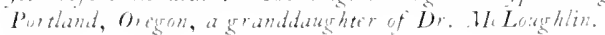




\title{
DR. JOHN McLOUGHLIN the Father of Oregon
}

\author{
BY \\ FREDERICK V. HOLMAN \\ Director of the Oregon Pioneer Association and of the \\ Oregon Historical Society
}

With Portraits

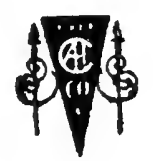

Cleveland, Ohio

The Arthur H. Clark Company

I 907 
COPYRIGHT, I9O7, BY

FREDERICK V. HOLMAN

ALL RIGHTS RESERVED 
70 the true, good, brave Oregon Pioneers 1 of 1843,1844, 1845, and 1846, whose coming in the time of ioint-occupancy did so much to help save Oregon and assisted in making it what it is today; whose affections and regards for Dr. Fohn McLoughlin and whose remembrances and heartfelt appreciations of his humanity and kindness to them and theirs can and could end only with their deaths, this volume is most respectfully dedicated. 



\section{CONTENTS}

PREFACE $\quad . \quad$. $\quad . \quad$.

TEXT .

Early Settlements and Joint-occupancy of the

Oregon Country . . . . . 20

The Hudson's Bay Company and the Northwest

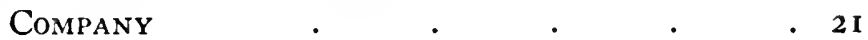

Genealogy and Family of Dr. John Mcloughlin 22

Mcloughlin and the Oregon Country • . 25

Fort VANCOUVer .

Punishment of Indians . . . . . 35

Early French Canadian Settlers . . • 4I

Early American Traders and Travellers . 45

Presbyterian Missionaries ..$\quad$. 52

Methodist Missions and Missionaries . 54

Provisional Government . . . . . . 64

IMMIGRATION OF 1842 . $\quad . \quad$. . . 69

IMMIGRATION OF 1843 . . . . . 70

IMMIGRATION OF 1844 . $\quad . \quad$. $\quad . \quad 78$

IMMIGRATION OF I845 . . . . . . 8

The Quality of the Early Immigrants • $\quad .83$

The Resignation of Dr. John McLoughlin. · 90

Dr. Mcloughlin's Religion . $\quad$. $\quad$. 98

Dr. Mcloughlin's Land Claim . . . ioi

AbERnethy IsLAND . . . . . . 114

The Shortess Petition . . . . . II6

Land Laws of the Provisional Government. - II9

Dr. Mcloughlin's Naturalization . • . I 20 
Conspiracy against Dr. McLoughlin

Thurston's Letter to Congress

Protests against Thurston's Actions

The Oregon Donation land Law.

The Conspiracy Effective.

. 143

Career and Death of Thurston.

. 144

The Methodist Episcopal Church .

. 146

Dr. McLoughlin's Memorial to Congress .

. 149

The Persecution Continued

The End of Dr. McLoughlin's Life.

Justice to Dr. McLoughlin's Meirory

Opinions by Dr. Mcloughlin's Contemporaries

. 162

Eulogy upon Dr. McLoughlin

ILLUSTRATIVE DOCUMENTS REFERRED TO IN THE TEXT:

A: Article 3 of Convention of October 20, 1818, between the United States and Great Britian

B: Convention of August 6, 1827, between the United States and Great Britian

C: Statement concerning merger of Hudson's Bay Company and Northwest Company; and grant to Hudson's Bay Company of 1821 and 1838 to trade in the Oregon Country

D: Excerpts from Manuscript Journal of Rev. Jason Lee

E: Rev. Jason Lee's visit to Eastern States in 1838; and his report to the Missionary Board at New York in 1844

F: Excerpts from Narrative of Commodore Charles Wilkes, U.S.N., published in Philadelphia in I 845

G: Letter from Henry Brallier to Frederick V. Holman of October 27, 1905 
H: Shortess Petition; excerpts from Gray's "History of Oregon" relating to Shortess Petition; and excerpt from speech of Samuel R. Thurston in Congress, December 26, 1850, as to author of Shortess Petition

I: Ricord's Proclamation; letters of A. Lawrence Lovejoy and Rev. A. F. Waller of March 2O, 1844; Ricord's Caveat; invalidity of Waller's claim to Dr. McLoughlin's land; and excerpts from letters of Rev. Jason Lee to Rev. A. F. Waller and Rev. Gustavus Hines, written in 1844

J: Agreement between Dr. John McLoughlin, Rev. A. F. Waller, and Rev. David Leslie, of April 4,1844 ; statement of cause and manner of making said agreement.

$\mathrm{K}$ : Statement of career in Oregon of Judge W. P. Bryant

L: Letter of Dr. John McLoughlin, published in the "Oregon Spectator" Thursday, September 12, I 850

M: Letter by William J. Berry, published in the "Oregon Spectator," December 26, 1850 . 243

N: Excerpts from speech of Samuel R. Thurston in Congress, December 26, 1850

O: Correspondence of S. R. Thurston, Nathaniel J. Wyeth, Robert C. Winthrop and Dr. John McLoughlin, published in the "Oregon Spectator," April 3, $1851 \quad$. $\quad$. $\quad 256$

P: Letter from Rev. Vincent Snelling to Dr. John McLoughlin of March 9, $1852 \quad$. 262

Q: Excerpts from "The Hudson's Bay Company and Vancouver's Island" by James Edward Fitzgerald, published in London in 1849; and excerpt from "Ten Years in Oregon," by Rev. 
Daniel Lee and Rev. J. H. Frost, published in New York in 1844 . $\quad .264$

R: Note on Authorship of "History of Oregon" in

Bancroft's Works; and sources of information for this monograph . . . . 270

S: Excerpts from opinions of contemporaries of Dr. McLoughlin 


\section{ILLUSTRATIONS}

Portrait of Dr. John McLoughlin, taken from daguerreotype of 1856 ; from original belonging to Mrs. Josiah Myrick, Portland, Oregon

Frontispiece

Portrait of Dr. John McLoughlin, taken from miniature painted on ivory, 1838 or 1839 ; from original belonging to Mrs. James W. McL. Harvey, Mirabel, California. facing p. 62 



\section{PREFACE}

THIS is a plain and simple narrative of the life of Dr. John McLoughlin, and of his noble career in the early history of Oregon. The writing of it is a labor of love on my part, for I am Oregonborn. A number of my near relatives came to Oregon overland in the immigrations of 1843,1845 , and 1846 . My father and mother came overland in 1846. The one great theme of the Oregon pioneers was and still is Dr. McLoughlin and his humanity. I came so to know of him that I could almost believe I had known him personally.

$\mathrm{He}$, the father of Oregon, died September third, 1857 , yet his memory is as much respected as though his death were of recent occurrence. In Oregon he will never be forgotten. $\mathrm{He}$ is known in Oregon by tradition as well as by history. His deeds are a part of the folk-lore of Oregon. His life is an essential part of the early, the heroic days of early Oregon. I know of him from the conversations of pioneers, who loved him, and from the numerous heart-felt expressions at the annual meetings of the Oregon pioneers, beginning with their first meeting. For years I have been collecting and reading books on early Oregon and the Pacific Northwest Coast. I am familiar with 
many letters and rare documents in the possession of the Oregon Historical Society relating to events in the time of the settlement of Oregon, and containing frequent references to Dr. McLoughlin.

October sixth, I905, was set apart as McLoughlin Day by the Lewis and Clark Exposition, at Portland, Oregon. I had the honor to be selected to deliver the address on that occasion. In writing that address I was obliged to familiarize myself with exact knowledge of dates and other important circumstances connected with the life and times of Dr. McLoughlin. In writing it, although I endeavored to be concise, the story grew until it went beyond the proper length for an address, and so I condensed it for oral delivery on McLoughlin Day.

Since that time I have largely rewritten it, and, while not changing the style essentially, I have added to it so that it has become a short history. For the benefit of those interested in Dr. John McLoughlin and the history of early Oregon, I have added notes and many documents. The latter show some of the sources from which I have drawn, but only some of them. They are necessary to a thorough understanding, particularly, as to the causes of his tribulations, and of what is due to him as a great humanitarian, and of his great services in the upbuilding of Oregon.

I have been kindly assisted by men and women still living who knew him personally, by those who gladly bear witness to what he was and what he did, and by those who have studied his life and times as a matter of historical interest. 
The full history of the life of Dr. John McLoughlin will be written in the future. Such a history will have all the interest of a great romance. It begins in happiness and ends in martyrdom. It is so remarkable that one unacquainted with the facts might doubt if some of these matters I have set forth could be true. Unfortunately they are true.

Frederick V. HolmaN

Portland, Oregon, January, i 907. 



\section{DR. JOHN MCLOUGHLIN}

THE story of the life of Dr. John McLoughlin comprises largely the history of Oregon beginning in the time of joint-occupancy of the Oregon Country, and continuing until after the boundary treaty dividing the Oregon Country between the United States and Great Britain, the establishment of the Oregon Territorial Government, and the passage of the Oregon Donation Law. It relates directly to events in Oregon from 1824 until the death of Dr. McLoughlin in 1857 , and incidentally to what occurred in Oregon as far back as the founding of Astoria in $18 \mathrm{r}$.

Prior to the Treaty of 1846 between the United States and England fixing the present northern boundary line of the United States west of the Rocky Mountains, what was known as the "Oregon Country" was bounded on the south by north latitude forty-two degrees, the present northern boundary of the states of California and Nevada; on the north by latitude fifty-four degrees and forty minutes, the present southern boundary of Alaska; on the east by the Rocky Mountains; and on the west by the Pacific Ocean. It included all of the states of Oregon, Washington, and Idaho, and parts of the states of Mon- 
tana and Wyoming, and all of the present Dominion of Canada between latitudes forty-nine degrees and fifty-four degrees forty minutes, and west of the Rocky Mountains. Its area was approximately four hundred thousand square miles, an area about twenty-five per cent. greater than that of the original thirteen colonies at the time of the American Revolution.

Early Settlements and Joint-occupancy of the Oregon Country.

The first permanent settlement on the Columbia River was made by the Pacific Fur Company, which was organized and controlled by John Jacob Astor. It founded Astoria March 22, I8II. October 16,1813 , during the war of 1812 , the establishments of the Pacific Fur Company in the Oregon Country, and all its furs and supplies, were sold, at less than one-third of their value, to the Northwest Company, of Montreal, by the treachery of Duncan McDougal, a partner of Astor in the Pacific Fur Company. December I, I813, the British sloop-of-war Raccoon arrived at Astoria and took formal possession of it in the name of the King of Great Britain. The captain of the Raccoon changed the name of Astoria to that of Fort George. Its name is now Astoria. The Northwest Company continued to carry on its business at Fort George and at other points in the Oregon Country until its coalition with the Hudson's Bay Company in I82 I.

The treaty of peace between the United States and England at the conclusion of the war of $I_{1} S_{2}$ was signed at Ghent, December 24, I8I4. It is 
known as the "Treaty of Ghent." Under this treaty Great Britain, on October 6, I8 18 , formally restored to the United States "the settlement of Fort George on the Columbia River." A Convention between the United States and Great Britain was signed October 20, I818. That Convention provided that the Oregon Country should be free and open, for the period of ten years, to the citizens and subjects of the two countries, being what is called for convenience joint-occupancy by the two countries. ${ }^{1}$ Another Convention between the two countries was made in 1827 , by which this joint-occupancy was continued indefinitely, subject to termination after October 20, I828, by either the United States or Great Britain giving to the other twelve months' notice. ${ }^{2}$ In April, I 846 , Congress passed a joint resolution giving the President authority, at his discretion, to give such notice to the British Government. Under the authority of this resolution President Polk signed a notice, dated April 28, I 846 , which by its terms was to go into effect from and after its delivery to the British Government at London. June 6, 1846, the British Government proposed the present boundary. This was accepted by the American Government. The treaty was signed at Washington, June 15, I 846 .

The Hudson's Bay Company and the Northwest Company.

The Hudson's Bay Company was established in I670 under a charter granted by King Charles II.

\footnotetext{
${ }^{1}$ See Document $A$ at end of volume.

${ }^{2}$ See Document B.
} 
The Northwest Company was formed in Montreal in $1783-4$. It became the great rival of the Hudson's Bay Company. Warfare occurred between the two companies, beginning in 1815 . A compromise was finally effected and in 1821 the Northwest Company coalesced with the Hudson's Bay Company. ${ }^{3}$ Dr. McLoughlin was a partner of the Northwest Company and opposed the coalition in a most determined manner. He would not sign the final agreement, as he considered it unfair to himself and to his associates in the Northwest Company. But the Hudson's Bay Company knew of Dr. McLoughlin, his resolution, his power, and his capacity, and it employed him as Chief Factor to manage and to build up the Company's business in the Oregon Country. He was given plenary powers. He was the man for the place and the time.

Genealogy and Family of Dr. John McLoughlin.

Dr. John McLoughlin was born October I9, 1784, in Parish La Rivière du Loup, Canada, about one hundred and twenty miles below Quebec, on the south side of the St. Lawrence River. He was baptized November 3, I784, at the Parish of Kamouraska, Canada, there being no Roman Catholic priest at La Rivière du Loup. Both of his parents were Roman Catholics. His father was John McLoughlin, a native of Ireland. Of him little is now known, excepting that he was a man of high character. He was accidentally drowned in the St. Lawrence River. The date I

\footnotetext{
See Document C.
} 
have been unable to ascertain. It was probably while his son John was quite young. For convenience I shall hereinafter speak of John McLoughlin, the younger, as Dr. John McLoughlin, or Dr. McLoughlin. His mother's maiden name was Angelique Fraser. She was a very fine woman. She was born in the Parish of Beaumont, Canada, and died in Canada, July 3,1842 , aged 83 years. Her father was Malcolm Fraser, a native of Scotland. At the time of his retirement from the army and settlement in Canada, in 1763 , he was a captain in the 84 th regiment of the British regular army. He was at one time a lieutenant in the 78 th regiment, known as the Fraser Highlanders. He spelled his name with two " $f$ 's" Ffraser. His daughter was also related to Gen. Fraser, one of Burgoyne's principal officers, who was killed at the battle of Saratoga, October 7, 1777 .

Dr. John McLoughlin's father and mother had seven children, of which five were daughters; the youngest daughter died while young. He was the second child, the eldest son, his only brother, David, being the third child. It is probable that Dr. John McLoughlin and his brother David were brought up in the home of their maternal grandfather. Their only maternal uncle was Samuel Fraser, M. D. He was a lieutenant in the Royal Highland Regiment (the famous "Black Watch" regiment). He took part in all the engagements fought by that regiment from 1795 to I803, in the Napoleonic wars. Their maternal relatives seem to have exercised a strong influence on 
both young John and David McLoughlin. They both became physicians. David served in the British army, and, after the Battle of Waterloo, practiced medicine in Paris, France. Dr. John McLoughlin was educated in Canada and Scotland. He joined the Northwest Company, which was composed and controlled by very active, practical, and forceful men. In 182 I he was in charge of Fort William, the chief depot and factory of the Northwest Company, when that Company coalesced with the Hudson's Bay Company. Fort William is situated on the north shore of Lake Superior, at the mouth of the Kaministiquia River. It was at Fort William, where he was stationed for a long time, that he became acquainted with the widow of Alexander McKay. Dr. McLoughlin married her, the exact date I have been unable to ascertain. Alexander McKay was a partner of John Jacob Astor in the Pacific Fur Company. He was killed in the capture, by Indians, of the ship Tonquin in June, I8I I, at Clayoquot Sound, on the west coast of Vancouver's Island.

Dr. John McLoughlin and wife had four children, whose names in order of birth were as follows: Eliza, John, Eloisa, and David. They are all dead. Eliza McLoughlin married Captain Epps, an officer in the English army. John McLoughlin, Jr., was murdered in April, I842, at Fort Stikeen, where he was in charge. Eloisa McLoughlin was Dr. McLoughlin's favorite child. She was married to William Glen Rae at Fort Vancouver in 1838 . Rae was appointed, after his marriage, a Chief Trader of the Hudson's 
Bay Company. In I 84 I he was sent to California to take charge of the Company's business at Yerba Buena, now San Francisco. He continued in charge there until his death in 1844 . All of their children are dead, excepting two-Mrs. Theodore Wygant and Mrs. Josiah Myrick, both now living in Portland. In October, 1850, Mrs. Rae was married to Daniel Harvey. There were three children by this second marriage, all of whom are now dead. Daniel Harvey died prior to his wife. She died at Portland in October, I884. In Portland and its vicinity there are now living several children of Mrs. Wygant and Mrs. Myrick, and also several grandchildren of Mrs. Wygant. At Mirabel, Sonoma County, California, there are now living a son, a daughter, and also the widow of James W. McL. Harvey, a son of Daniel and Eloisa Harvey. A son of Mrs. Myrick is living at Los Angeles, California. David McLoughlin, the youngest child of Dr. McLoughlin, was educated in England. He returned to Oregon, and later made his home in Idaho, where he died at an advanced age.

\section{Dr. McLouglin and the Oregon Country.}

Physically Dr. John McLoughlin was a superb specimen of man. His height was not less than six feet four inches. He carried himself as a master, which gave him an appearance of being more than six feet and a half high. He was almost perfectly proportioned. Mentally he was endowed to match his magnificent physical proportions. He was brave and fearless; he was true and just; he was 
truthful and scorned to lie. The Indians, as well as his subordinates, soon came to know that if he threatened punishment for an offense, it was as certain as that the offense occurred. He was absolute master of himself and of those under him. He allowed none of his subordinates to question or to disobey. This was necessary to conduct the business of his Company, and to preserve peace in the vast Oregon Country. He was facile princeps. And, yet, with all these dominant qualities, he had the greatest kindness, sympathy, and humanity. He needed all his stern and manlike characteristics to govern the officers, employées, servants, and dependents of his Company, and to conduct its business, in the Oregon Country. Here was a great empire in physical extent, intersected by great rivers and chains of mountains. There was no one on whom he could depend, except his under-officers and the Company's servants. To him were given no bands of trained soldiers to govern a country half again larger than the Empire of Germany, and occupied by treacherous, hostile, crafty, and cruel savages; and to so govern as not to be to the prejudice, nor to the exclusion, of citizens of the United States, nor to encourage them, nor to help them.

When he first came to Oregon, it was not safe for the Company's parties to travel except in large numbers and heavily armed. In a few years there was practically no danger. A single boat loaded with goods or furs was as safe as a great flotilla had been when he arrived on the Columbia River in I824. It was Dr. John McLoughlin who did this, 
by his personality, by his example, and by his influence. He had accomplished all this when the Indian population of the Oregon Country is estimated to have been in excess of 100,000 , including about 30,000 on the Columbia River below its junction with Snake River, and on the tributaries of that part of the Columbia River. This was before the great epidemics of the years 1829 to 1832 , inclusive, which caused the deaths of great numbers of the Indians, especially those living on and near the lower Columbia River. There were no Indian wars in the Oregon Country during all the time Dr. McLoughlin was in charge at Fort Vancouver, from 1824 to 1846 . All the Indian wars in the Oregon Country occurred after he resigned from the Hudson's Bay Company. The first of these wars began with the Whitman massacre in 1847 .

When he came to Oregon, he was nearly forty years old. His hair was then almost white, and was worn long, falling almost to his shoulders. It did not take long for the Indians to know him and to give him a name. To some of the Indians he was the "White-Headed Eagle," and to others, the "Great White Chief."

\section{Fort Vancouver.}

Dr. McLoughlin came overland to Fort George (Astoria), arriving there in 1824 . He soon saw that the place for a great trading and supply post should be further up the Columbia River. After careful surveys in small boats, he founded Fort Vancouver, on the north side of the Columbia 
River, about seven miles above the mouth of the Willamette River, and several miles below the point named Point Vancouver by Lieut. Broughtan, in I792, the latter point being near the present town of Washougal, Washington. In I825 Fort Vancouver was constructed, in part, and the goods and effects at Fort George were moved to Fort Vancouver. The final completion of the latter fort was not until a later period, although the work was carried on as rapidly as possible. A few years after, about 1830 , a new fort was erected about a mile westerly from the original fort. Here is now located the present United States' Military post, commonly known as Vancouver Barracks.

With characteristic energy and foresight Dr. McLoughlin soon established at and near Fort Vancouver a large farm on which were grown quantities of grain and vegetables. It was afterwards stocked with cattle, horses, sheep, goats, and hogs. In 1836 this farm consisted of 3,000 acres, fenced into fields, with here and there dairy houses and herdsmen's and shepherd's cottages. In 1836 the products of this farm were, in bushels: 8 , o0o of wheat; 5,500 of barley; 6,000 of oats; 9,000 of peas; 14,000 of potatoes; besides large quantities of turnips (rutabaga), pumpkins, etc. ${ }^{4}$ There were about ten acres in apple, pear, and quince trees, which bore in profusion. He established two saw mills and two flour mills near the fort. For many years there were shipped, from Fort Vancouver, lumber to the Hawaiian Islands (then

\footnotetext{
${ }^{4}$ Report of Naval Agent W. A. Slocum to the Secretary of State, March 26, 1837 .
} 
called the Sandwich Islands) and flour to Sitka. It was not many years after Dr. McLoughlin came to the Oregon Country until it was one of the most profitable parts of North America to the Hudson's Bay Company. For many years the London value of the yearly gathering of furs, in the Oregon Country, varied from $\$ 500,000$ to $\$ 1,000,000$, sums of money representing then a value several fold more than such sums represent today.

Fort Vancouver was a parallelogram about seven hundred and fifty feet long and four hundred and fifty broad, enclosed by an upright picket wall of large and closely fitted beams, over twenty feet in height, secured by buttresses on the inside. Originally there was a bastion at each angle of the fort. In the earlier times there were two twelve pounders mounted in these bastions. In the center of the fort there were some eighteen pounders; all these cannon, from disuse, became merely ornamental early in the thirties. ${ }^{5}$ In I841, when Commodore Wilkes was at Fort Vancouver, there were between the steps of Dr. McLoughlin's residence, inside the fort, two old cannon on sea-carriages, with a few shot. There were no other warlike instruments. ${ }^{6}$ It was a very peaceful fort.

The interior of the fort was divided into two courts, having about forty buildings, all of wood except the powder magazine, which was constructed of brick and stone. In the center, facing the main entrance, stood the Hall in which were the dining-room, smoking-room, and public sit-

\footnotetext{
${ }^{5}$ Dunn's History of the Oregon Territory, p. 143.

${ }^{8}$ Wilkes's Narrative, iv, p. 327.
} 
ting-room, or bachelor's hall. Single men, clerks, strangers, and others made the bachelor's hall their place of resort. To these rooms artisans and servants were not admitted. The Hall was the only two-story house in the fort. The residence of Dr. McLoughlin was built after the model of a French Canadian dwelling-house. It was one story, weather-boarded, and painted white. It had a piazza with vines growing on it. There were flower-beds in front of the house. The other buildings consisted of dwellings for officers and their families, a school-house, a retail store, warehouses and shops.

A short distance from the fort, on the bank of the river, was a village of more than fifty houses, for the mechanics and servants, and their families, built in rows so as to form streets. Here were also the hospital, boat-house, and salmon-house, and near by were barns, threshing-mills, granaries, and dairy buildings. The whole number of persons, having their homes at Fort Vancouver and its vicinity, men, women, and children, was about eight hundred. The Hall was an oasis in the vast social desert of Oregon. Fort Vancouver was a fairy-land to the early travellers, after their long, hard journeys across the continent. Thomas J. Farnham was a traveller who came to Oregon in I839. He was entertained by Dr. McLoughlin at Fort Vancouver. In his account of his travels, which he subsequently published, he gives the following description of the usual dinner at Fort Vancouver:

"The bell rings for dinner; we will now pay a 
visit to the 'Hall' and its convivialities.

At the end of a table twenty feet in length stands Governor McLoughlin, directing guests and gentlemen from neighboring posts to their places; and chief-traders, traders, the physician, clerks, and the farmer slide respectfully to their places, at distances from the Governor corresponding to the dignity of their rank in the service. Thanks are given to God, and all are seated. Roast beef and pork, boiled mutton, baked salmon, boiled ham; beets, carrots, turnips, cabbage, and potatoes, and wheaten bread, are tastefully distributed over the table among a dinner-set of elegant queen's ware, burnished with glittering glasses and decanters of various-coloured Italian wines. Course after course goes round, . . . and each gentleman in turn vies with him in diffusing around the board a most generous allowance of viands, wines, and warm fellow-feeling. The cloth and wines are removed together, cigars are lighted, and a strolling smoke about the premises, enlivened by a courteous discussion of some mooted point of natural history or politics, closes the ceremonies of the dinner hour at Fort Vancouver."

At Fort Vancouver Dr. John McLoughlin lived and ruled in a manner befitting that of an old English Baron in feudal times, but with a graciousness and courtesy, which, I fear, were not always the rule with the ancient Barons. Dr. McLoughlin was a very temperate man. He rarely drank any alcoholic beverages, not even wines. There was an exception one time, each year, when the festivities began at Fort Vancouver on the return of the 
brigade, with the year's furs. He then drank a glass of wine to open the festivities. Soon after he came to Oregon, from morality and policy he stopped the sale of liquor to Indians. To do this effectually he had to stop the sale of liquor to all whites. In 1834 , when Wyeth began his competition with the Hudson's Bay Company, he began selling liquor to Indians, but at the request of $\mathrm{Dr}$. McLoughlin, Wyeth stopped the sale of liquors to Indians as well as to the whites. In I84I the American trading vessel Thomas Perkins, commanded by Captain Varney, came to the Columbia River to trade, having a large quantity of liquors. To prevent the sale to the Indians, Dr. McLoughlin bought all these liquors and stored them at Fort Vancouver. They were still there when Dr. McLoughlin left the Hudson's Bay Company in I 846.

Dr. McLoughlin soon established numerous forts and posts in the Oregon Country, all of which were tributary to Fort Vancouver. In 1839 there were twenty of these forts besides Vancouver. The policy of the Hudson's Bay Company was to crush out all rivals in trade. It had an absolute monopoly of the fur trade of British America, except the British Provinces, under acts of Parliament, and under royal grants. But in the Oregon Territory its right to trade therein was limited by the Conventions of 1818 and 1827 and by the act of Parliament of July 2, I 82 I, to the extent that the Oregon Country (until one year's notice was given) should remain free and open to the citizens of the United States and to the subjects of Great 
Britain, and the trade of the Hudson's Bay Company should not "be used to the prejudice or exclusion of citizens of the United States engaged in such trade." " Therefore, as there could be no legal exclusion of American citizens, it could be done only by occupying the country, building forts, establishing trade and friendly relations with the Indians, and preventing rivalry by the laws of trade, including ruinous competition. As the Hudson's Bay Company bought its goods in Targe quantities in England, shipped by sea, and paid no import duties, it could sell at a profit at comparatively low prices. In addition, its goods were of extra good quality, usually much better than those of the American traders. It also desired to prevent the settling of the Oregon Country. The latter purpose was for two reasons: to preserve the fur trade; and to prevent the Oregon Country from being settled by Americans to the prejudice of Great Britain's claim to the Oregon Country.

For more than ten years after Dr. McLoughlin came to Oregon, there was no serious competition to the Hudson's Bay Company in the Oregon Country west of the Blue Mountains. An occasional ship would come into the Columbia River and depart. At times, American fur traders entered into serious competition with the Hudson's Bay Company, east of the Blue Mountains. Such traders were Bonneville, Sublette, Smith, Jackson, and others. They could be successful, only partially, against the competition of the Hudson's Bay Company. Goods were often sold by it at prices

? See Document C. 
which could not be met by the American traders, except at a loss. Sometimes more was paid to the Indians for furs than they were worth.

Dr. McLoughlin was the autocrat of the Oregon Country. His allegiance was to his Country and to his Company. He knew the Americans had the legal right to occupy any part of the Oregon Country, and he knew from the directors of his Company, as early as 1825 , that Great Britain did not intend to claim any part of the Oregon Country south of the Columbia River. The only fort he established south of the Columbia River was on the Umpqua River. I do not wish to place Dr. McLoughlin on a pedestal, nor to represent him as more than a grand and noble man, ever true, as far as possible, to his Company's interests and to himself. To be faithless to his Company was to be a weakling and contemptible. But he was not a servant, nor was he untrue to his manhood. As Chief Factor he was "Ay, every inch a King," but he was also ay, every inch a man. $\mathrm{He}$ was a very human, as well as a very humane man. He had a quick and violent temper. His position as Chief Factor and his continued use of power often made him dictatorial. And yet he was polite, courteous, gentle, and kind, and a gentleman. He was an autocrat, but not an aristocrat. In 1838 Rev. Herbert Beaver, who was chaplain at Fort Vancouver, was impertinent to Dr. McLoughlin in the fort-yard. Immediately Dr. McLoughlin struck Beaver with a cane. The next day Dr. McLoughlin publicly apologized for this indignity. 
Punishment of Indians.

The policy of the Company, as well as that of Dr. McLoughlin, was to keep Americans, especially traders, out of all the Oregon Country. The difference was that he believed that they should be kept out only so far as it could be done lawfully. But he did not allow them to be harmed by the Indians, and, if the Americans were so harmed, he punished the offending Indians, and he let all Indians know that he would punish for offenses against the Americans as he would for offenses against the British and the Hudson's Bay Company. Personally he treated these rival traders with hospitality. In his early years in Oregon on two occasions he caused an Indian to be hanged for murder of a white man. In 1829 , when the Hudson's Bay Company's vessel, William and Ann, was wrecked on Sand Island, at the mouth of the Columbia River, and a part of her crew supposed to have been murdered and the wreck looted, he sent a well armed and manned schooner and a hundred voyageurs to punish the Indians.

- Jedediah S. Smith was a rival trader to the Hudson's Bay Company. In 1828 all his party of eighteen men, excepting four, one of which was Smith, were murdered by the Indians, near the mouth of the Umpqua River. All their goods and furs were stolen. These four survivors arrived at Fort Vancouver, but not all together. They were all at the point of perishing from exhaustion and were nearly naked. All their wants were at once supplied, and they received the kindest treatment. When the first one arrived Dr. McLoughlin sent 
Indian runners to the Willamette chiefs to tell them to send their people in search of Smith and his two men, and if found to bring them to Fort Vancouver, and Dr. McLoughlin would pay the Indians; and also to tell these chiefs that if Smith, or his men, was hurt by the Indians, that Dr. McLoughlin would punish them. Dr. McLoughlin sent a strong party to the Umpqua River, which recovered these furs. They were of large value. Smith at his own instance sold these furs to the Hudson's Bay Company, receiving the fair value for the furs, without deduction. Dr. McLoughlin later said of this event that it "was done from a principle of Christian duty, and as a lesson to the Indians to show them they could not wrong the whites with impunity." The effect of this Smith matter was far-reaching and long-continued. The Indians understood, even if they did not appreciate, that the opposition of Dr. McLoughlin to Americans as traders did not apply to them personally.

Dunn, in his History of the Oregon Territory, narrates the following incident: ${ }^{8}$ "On one occasion an American vessel, Captain Thompson, was in the Columbia, trading furs and salmon. The vessel had got aground, in the upper part of the river, and the Indians, from various quarters, mustered with the intent of cutting the Americans off, thinking that they had an opportunity of revenge, and would thus escape the censure of the

${ }^{8}$ John Dunn was an employée of the Hudson's Bay Company. He came from England to Fort Vancouver, in 1830 , by sea. He returned to England in 1839 or 1840 . The first edition of his history was published in London in 1844 . 
company. Dr. McLoughlin, the governor of Fort Vancouver, hearing of their intention, immediately despatched a party to their rendezvous; and informed them that if they injured one American, it would be just the same offence as if they had injured one of his servants, and they would be treated equally as enemies. This stunned them; and they relinquished their purpose; and all retired to their respective homes. Had not this come to the governor's ears the Americans must have perished."

In 1842 the Indians in the Eastern Oregon Country became alarmed for the reason that they believed the Americans intended to take away their lands. The Indians knew that the Hudson's Bay Company and its employées were traders and did not care for lands, except as incidental to trading. At this time some of the Indians desired to raise a war party and surprise and massacre the American settlements in the Willamette Valley. This could have been done easily at that time. Through the influence of Dr. McLoughlin with Peopeomoxmox (Yellow Serpent), a chief of the Cayuses, this trouble was averted. In 1845 a party of Indians went to California to buy cattle. An American there killed Elijah, the son of Peopeomoxmox. The Indians of Eastern Oregon threatened to take two thousand warriors to California and exterminate the whites there. Largely through the actions of Dr. McLoughlin the Indians were persuaded to abandon their project.

John Minto, a pioneer of 1844 , in an address February 6, 1889, narrated the following incident. 
In I843 two Indians, for the purpose of robbery, at Pillar Rock, in the lower Columbia, killed a servant of the Hudson's Bay Company. One of the Indians was killed in the pursuit. The other was taken, after great trouble. There was no doubt as to his guilt. In order to make the lesson of his execution salutary and impressive to the Indians, Dr. McLoughlin invited the leading Indians of the various tribes, as well as all classes of settlers and missionaries, to be present. He made the arrangements for the execution in a way best calculated to strike terror to the Indian mind. When all was ready, and immediately prior to the execution, with his white head bared, he made a short and earnest address to the Indians, showing them that the white men of all classes, Englishmen, Americans, and Frenchmen, were as one man to punish such crimes. In a technical sense Dr. McLoughlin had no authority to cause Indians to be executed or to compel them to restore stolen goods, as in the William and Ann matter and the Jedediah S. Smith case.

Under the act of Parliament of July, I82I, the courts of judicature of Upper Canada were given jurisdiction of civil and criminal matters within the Indian territories and other parts of America not within the Provinces of Lower or Upper Canada, or of any civil government of the United States. Provisions were made for the appointment of justices of the peace in such territories, having jurisdiction of suits or actions not exceeding two hundred pounds, and having jurisdiction of ordinary criminal offenses. But it was expressly 
provided that such justices of the peace should not have the right to try offenders on any charge of felony made the subject of capital punishment, or to pass sentence affecting the life of any offender, or his transportation; and that in case of any offense, subjecting the person committing the same to capital punishment or to transportation, to cause such offender to be sent, in safe custody, for trial in the court of the Province of Upper Canada. As to how far this law applied to Indians or to others than British subjects or to residents of the Oregon Country under joint-occupancy, it is not necessary here to discuss. It certainly did not apply to citizens of the United States. So far as I can learn, Dr. McLoughlin was never appointed such a justice of the peace, but he caused his assistant James Douglas to be so appointed, at Fort Vancouver.

As under joint-occupancy it was doubtful if either the laws of the United States or of Great Britain were in force in the Oregon Country, it was necessary for some one to assume supreme power and authority over the Indians, in the Willamette Valley, until the Oregon Provisional Government was established, and over the remainder of the Oregon Country, at least, until the boundaryline treaty was made. It was characteristic of Dr. McLoughlin that he assumed and exercised such power and authority, until he ceased to be an officer of the Hudson's Bay Company. He did so without question. It is true that this might have been an odious tyranny under a different kind of a man. Under Dr. McLoughlin it was a kind of despotism, but a just and beneficent despotism, 
under the circumstances. It was a despotism tempered by his sense of justice, his mercy, his humanity, and his common-sense. No man in the Oregon Country ever knew the Indian character, or knew how to control and to manage Indians as well as Dr. McLoughlin did. The few severe and extreme measures he took with them as individuals and as tribes were always fully justified by the circumstances. To have been more lenient might have been fatal to his Company, its employées, and the early white settlers in the Oregon Country. They were of the few cases where the end justifies the means. The unusual conditions justified the unusual methods.

The Oregon Provisional Government was not a government in the true meaning of the word, it was a local organization, for the benefit of those consenting. It had no true sovereignty. And yet it punished offenders. It waged the Cayuse Indian war of $1847-8$, caused by the Whitman massacre. It would have executed the murderers if it had caught them, although the scenes of the massacre and of the war were several hundred miles beyond the asserted jurisdiction of the Oregon Provisional Government. And it would have been justified in case of such executions. The war was a necessity, law or no law. Every act of punitive or vindicatory justice to the Indians by $\mathrm{Dr}$. McLoughlin is greatly to his credit. These acts caused peace in the Oregon Country and were beneficial to the Indians as well as to the whites, both British and American, and, in the end, probably saved numerous massacres and hundreds of 
lives. Dr. McLoughlin was a very just and farseeing man. I shall presently tell how Dr. McLoughlin saved the immigrants of 1843 from great trouble and probable massacre by the Indians.

\section{Early French Canadian Settlers.}

After the death of Dr. McLoughlin there was found among his private papers a document in his own handwriting. This was probably written shortly prior to his death. It gives many interesting facts, some of which I shall presently set forth. This document was given to Col. J. W. Nesmith by a descendant of Dr. McLoughlin. It was presented to the Oregon Pioneer Association by Col. Nesmith in 1880 . It was printed at length in the Transactions of that Association for that year, pages 46-55. I shall hereinafter refer to this document as "the McLoughlin Document." In the McLoughlin Document he says: "In 1825, from what I had seen of the country, I formed the conclusion, from the mildness and salubrity of the climate, that this was the finest portion of North America that I had seen for the residence of civilized man." The farm at Fort Vancouver showed that the wheat was of exceptionally fine quality. Dr. McLoughlin knew that where wheat grew well and there was a large enough area, that it would become a civilized country, especially where there was easy access to the ocean. Thus early he saw that what is now called Western Oregon was bound to be a populous country. It was merely a question of time. It was evidently with 
this view that he located his land claim at Oregon City in 1829 . If settlers came he could endeavor to have them locate in the Willamette Valley, and thus preserve, to a great extent, the fur animals in other parts of the Oregon Country, and especially north of the Columbia River.

The Hudson's Bay Company was bound, under heavy penalties, not to discharge any of its servants in the Indian country, and was bound to return them to the places where they were originally hired. As early as 1828 several French Canadian servants, or employées, whose times of service were about ended, did not desire to return to Canada, but to settle in Oregon. They disliked to settle in the Willamette Valley, notwithstanding its fertility and advantages, because they thought that ultimately it would be American territory, but Dr. McLoughlin told them that he knew "that the American Government and people knew only two classes of persons, rogues and honest men. That they punished the first and protected the last, and it depended only upon themselves to what class they would belong." Dr. McLoughlin later found out, to his own sorrow and loss, that he was in error in this statement. These French Canadians followed his advice. To allow these French Canadians to become settlers, he kept them nominally on the books of the Hudson's Bay Company as its servants. He made it a rule to allow none of these servants to become settlers unless he possessed fifty pounds sterling to start with. He loaned each of them seed and wheat to plant, to be returned from the produce of his farm, and sold him implements 
and supplies at fifty per cent. advance on prime London cost. The regular selling price at Fort Vancouver was eighty per cent. advance on prime London cost. Dr. McLoughlin also loaned each of these settlers two cows, the increase to belong to the Hudson's Bay Company, as it then had only a small herd, and he wished to increase the herd. If any of the cows died, he did not make the settler pay for the animal. If he had sold the cattle the Company could not supply other settlers, and the price would be prohibitive, if owned by settlers who could afford to buy, as some settlers offered him as high as two hundred dollars for a cow. Therefore, to protect the poor settlers against the rich, and to make a herd of cattle for the benefit of the whole country, he refused to sell to any one.

In 1825 Dr. McLoughlin had at Fort Vancouver only twenty-seven head of cattle, large and small. He determined that no cattle should be killed, except one bull-calf every year for rennet to make cheese, until he had an ample stock to meet all demands of his Company, and to assist settlers, a resolution to which he strictly adhered. The first animal killed for beef was in 1838 . Until that time the Company's officers and employées had lived on fresh and salt venison and salmon and wild fowl.

In August 1839, the expedition of Sir Edward Belcher was at Fort Vancouver. Dr. McLoughlin was not then at Fort Vancouver. He probably had not returned from his trip to England in I838-9. James Douglas was in charge. Although 
the latter supplied Sir Edward Belcher and his officers with fresh beef, Douglas declined to furnish a supply of fresh beef for the crew, because he did not deem it prudent to kill so many cattle. Sir Edward Belcher complained of this to the British government. ${ }^{9}$ Dr. McLoughlin gave the American settlers, prior to 1842 , the same terms as he gave to the French Canadian settlers. But some of these early American settlers were much incensed at the refusal of Dr. McLoughlin to sell the cattle, although they accepted the loan of the cows. It has been asserted that Dr. McLoughlin intended to maintain a monopoly in cattle. But if that was his intention, as he refused to sell, where was to be the profit? The Hudson's Bay Company was a fur-trading Company. It was not a cattledealing Company. If Dr. McLoughlin intended to create a monopoly, he himself assisted to break it. That such was not his intention is shown by his helping the settlers to procure cattle from California in 1836 .

In 1836 a company was formed to go to California to buy cattle and drive them to Oregon overland. About twenty-five hundred dollars was raised for this purpose, of which amount Dr. McLoughlin, for the Hudson's Bay Company, subscribed about half. The number of cattle which were thus brought to Oregon was six hundred and thirty, at a cost of about eight dollars a head. In the McLoughlin Document he says: "In the Willamette the settlers kept the tame and broken-in oxen they had, belonging to the Hud-

\footnotetext{
${ }^{8}$ Belcher's Narrative of a Voyage Round the World, vol. i, p. 296.
} 
son's Bay Company, and gave their California wild cattle in the place, so that they found themselves stocked with tame cattle which cost them only eight dollars a head, and the Hudson's Bay Company, to favor the settlers, took calves in place of grown up cattle, because the Hudson's Bay Company wanted them for beef. These calves would grow up before they were required."

Early American Traders and Travellers.

In $1_{32}$ Nathaniel J. Wyeth of Cambridge, Massachusetts, came overland with a small party, expecting to meet in the Columbia River, a vessel with supplies, to compete with the Hudson's Bay Company. The vessel was wrecked in the South Pacific Ocean. She and the cargo were a total loss. This party arrived at Fort Vancouver in a destitute condition. Although Dr. McLoughlin knew they came as competing traders, he welcomed them cordially, supplied their necessities on their credit, and gave Wyeth a seat at his own table. In Wyeth's Journal of this expedition he says, under date of October 29, 1832 : "Arrived at the fort of Vancouver. . . Here I was received with the utmost kindness and hospitality by Dr. McLoughlin, the acting Governor of the place.

Our people were supplied with food and shelter. . . . I find Dr. McLoughlin a fine old gentleman, truly philanthropic in his ideas.

The gentlemen of this Company do much credit to their country by their education, deportment, and talents. . . . The Company seem disposed to render me all the assistance they can." Wyeth 
was most hospitably entertained by Dr. McLoughlin until February 3, I833, when Wyeth left Vancouver for his home overland. He was accompanied by three of his men, the others staying at Fort Vancouver. In his Journal under date February 3,1833 , he says: "I parted with feelings of sorrow from the gentlemen of Fort Vancouver. Their unremitting kindness to me while there much endeared them to me, more so than would seem possible during so short a time. Dr. McLoughlin, the Governor of the place, is a man distinguished as much for his kindness and humanity as his good sense and information; and to whom I am so much indebted as that he will never be forgotten by me." Dr. McLoughlin assisted the men of Wyeth's expedition who stayed, to join the Willamette settlement. He furnished them seed and supplies and agreed that they would be paid the same price for their wheat as was paid to the French Canadian settlers, i.e., three shillings, sterling, per bushel, and that they could purchase their supplies from the Hudson's Bay Company at fifty per cent. advance on prime London cost. This is said to have been equivalent to paying one dollar and twenty-five cents a bushel for wheat, with supplies at customary prices.

In 1834 Wyeth again came overland to the Columbia River with a large party. On the way he established Fort Hall (now in Idaho) in direct opposition to the Hudson's Bay Company, as he had a perfect right to do. He and his party arrived at Fort Vancouver September I4, I834, and were hospitably received by Dr. McLoughlin and the 
other gentlemen of the Hudson's Bay Company. In Wyeth's Journal of his second expedition he says, under date of September 14, I834: "Arrived at Vancouver, where I found Dr. McLoughlin in charge, who received us in his usual nianner. He has here power, and uses it as a man should, to make those about him, and those who come in contact with him, comfortable and happy." The brig May Dacre, with Wyeth's supplies, was then in the Columbia River. Immediately on his arrival, Wyeth started in active competition with the Hudson's Bay Company. He established a post, which he named Fort William, on Wappatoo Island (now Sauvie's Island). He forwarded supplies and men to Fort Hall. It was the beginning of a commercial war between the two companies, but it was a warfare on honorable lines. In the end Wyeth was beaten by Dr. McLoughlin, and sold out his entire establishment to the Hudson's Bay Company. While Dr. McLoughlin was personally courteous to Wyeth and his employées, he did not and would not be false or untrue to the business interests of the Hudson's Bay Company. For Dr. McLoughlin to have acted otherwise than he did, would have shown him to be unfit to hold his position as Chief Factor. Wyeth was too big, and too capable a man not to understand this. In his Journal, under date of September 31, I834, (he evidently forgot that September has but thirty days) he says: "From this time until the $13^{\text {th Oct. }}$ making preparations for a campaign into the Snake country and arrived on the I $3^{\text {th }}$ at Vancouver and was received with great attention by all there." 
And under date of February 12, 1835, he says: "In the morning made to Vancouver and found there a polite reception." 10 Wyeth was a man of great ability, enterprise, and courage. His expeditions deserved better fates. He was a high-minded gentleman. Although his two expeditions were failures, he showed his countrymen the way to Oregon, which many shortly followed.

In the McLoughlin Document he says: "In justice to Mr. Wyeth I have great pleasure to be able to state that as a rival in trade, I found him open, manly, frank, and fair. And, in short, in all his contracts, a perfect gentleman and an honest man, doing all he could to support morality and encouraging industry in the settlement." It is pleasing to know that after all his hardships and misfortunes Wyeth established a business for the exportation of ice from Boston to Calcutta, which was a great financial success.

Rev. H. K. Hines, D.D., was a Methodist minister who came to Oregon in 1853 . He was a brother of Rev. Gustavus Hines, the Methodist missionary, who came to Oregon in 1840 , on the ship Lausanne. December Io, I 897, at Pendleton, Oregon, Rev. Dr. Hines delivered one of the finest tributes to Dr. McLoughlin that I know of. He was fully capable to do it, for he was a profound and scholarly student of Oregon history, and personally knew Dr. McLoughlin. His address should be read by everyone. In his address Rev. Dr. Hines said, speaking in regard to the failure

\footnotetext{
${ }^{10}$ As to the high regard which Wyeth retained through his life for Dr. McLoughlin, see Document O.
} 
of the enterprises of Wyeth, Bonneville, and other fur traders in opposition to the Hudson's Bay Company: "My own conclusion, after a lengthy and laborious investigation, the result I have given here in bare outlines, is that Dr. McLoughlin acted the part only of an honorable, high-minded, and loyal man in his relation with the American traders who ventured to dispute with him the commercial dominion of Oregon up to 1835 or I 837. When Wyeth left Oregon in 1835 , he left on the Columbia River a number of men. These, too, were assisted by Dr. McLoughlin to join the Willamette River settlements. They were given the same terms as to prices of wheat and on supplies as he had given to the French Canadian, and to the other American settlers. In assisting these men whom Wyeth left on his two expeditions, Dr. McLoughlin was actuated by two motives. The first was humanitarian; the second was the desirability, if not necessity, of not having men, little accustomed to think or to plan for themselves, roaming the country, and possibly, some of them, becoming vagabonds. It was liable to be dangerous for white men to join Indian tribes and become leaders. With great wisdom and humanity he made them settlers, which gave them every inducement to be industrious and to be law abiding.

John K. Townsend, the naturalist, accompanied by Nuttall, the botanist, crossed the plains in 1834 with Captain Wyeth. In I839 Townsend published a book entitled, "Narrative of a Journey across the Rocky Mountains," etc. On page I69 he says: "On the beach in front of the fort, we 
were met by Mr. Lee, the missionary, and Dr. John McLoughlin, the Chief Factor, and Governor of the Hudson's Bay posts in this vicinity. The $\mathrm{Dr}$. is a large, dignified and very noble looking man, with a fine expressive countenance, and remarkably bland and pleasing manners. The Missionary introduced Mr. N. [Nuttall] and myself in due form, and we were greeted and received with a frank and unassuming politeness which was most peculiarly grateful to our feelings. He requested us to consider his house our home, provided a separate room for our use, a servant to wait upon us, and furnished us with every convenience which we could possibly wish for. I shall never cease to feel grateful to him for his disinterested kindness to the poor, houseless, and travelworn strangers." And on page 263 he said: "I took leave of Doctor McLoughlin with feelings akin to those with which I should bid adieu to an affectionate parent; and to his fervent, 'God bless you, sir, and may you have a happy meeting with your friends,' I could only reply by a look of the sincerest gratitude. Words are inadequate to express my deep sense of the obligations which I feel under to this truly generous and excellent man, and I fear I can only repay them by the sincerity with which I shall always cherish the recoliection of his kindness, and the ardent prayers I shall breathe for his prosperity and happiness."

The only persons who were not cordially received by Dr. McLoughlin were Ewing Young and Hall J. Kelley, who came to Fort Vancouver in October, 1834, from California. Gov. Figu- 
eroa, the Governor of California, had written Dr. McLoughlin that Young and Kelley had stolen horses from settlers in California. Dr. McLoughlin told them of the charges, and that he would have nothing to do with them until the information was shown to be false. This was not done until long afterwards, when it was shown that neither Young nor Kelley was guilty, but that some of their party, with which they started to Oregon, were guilty, and were disreputable characters, which Young and Kelley knew. The stand taken by Dr. McLoughlin was the only proper one. He had official information from California. Fort Vancouver was not an asylum for horse thieves. Nevertheless, as Kelley was sick, Dr. McLoughlin provided Kelley with a house, such as was occupied by the servants of the Company, outside the fort, furnished him with an attendant, and supplied him with medical aid and all necessary comforts until March, 1835, when Dr. McLoughlin gave Kelley free passage to the Hawaiian Islands on the Hudson's Bay Company's vessel, the Dryad, and also presented Kelley with a draft for seven pounds sterling, payable at the Hawaiian Islands. On his return home, Kelley, instead of being grateful, most vigorously attacked the Hudson's Bay Company for its alleged abuses of American citizens, and abused Dr. McLoughlin and falsely stated that Dr. McLoughlin had been so alarmed with the dread that Kelley would destroy the Hudson's Bay Company's trade that Dr. McLoughlin had kept a constant watch over Kelley. 
Kelley was a Boston school teacher who became an Oregon enthusiast. From the year I815, when he was twenty-six years of age, for many years, he wrote and published pamphlets and also a few books on Oregon and its advantages as a country to live in. He originated a scheme to send a colony to Oregon; to build a city on the east side of the Willamette River, at its junction with the Columbia River; and to build another city on the north side of the Columbia River, nearly opposite Tongue Point. His efforts resulted in immediate failures. He died a disappointed man. Young was a type of a man who was often successful in the Far West. He was forceful and self-reliant, but often reckless, and sometimes careless of appearances. He was so accustomed to meet emergencies successfully that he did not always consider what others might think of him and of the methods he sometimes felt compelled to adopt. He had been robbed in California of a large amount of furs and had not been fairly treated by the representatives of the Mexican Government in California. While Young was an adventurer, he was a man of ability and became a leading resident of early Oregon. The relations of Dr. McLoughlin and Ewing Young finally became quite amicable, for Dr. McLoughlin learned of and respected Young's good and manly qualities.

Presbyterian Missionaries.

For convenience I shall first mention the Presbyterian missionaries, although they came two years later than the first Methodist missionaries. 
Rev. Samuel Parker was the first Presbyterian minister to arrive in Oregon. He came in 1835 . He started to Oregon with Doctor Marcus Whitman, but Whitman returned East from Green River to obtain more associates for the Mission. These came out with Dr. Whitman in 1836 . Parker returned home by sea, reaching his home in 1837 . Parker published a book called, "Journal of an Exploring Tour beyond the Rocky Mountains." The first edition was published in Ithaca, New York, in I 838 . On page 138 of his book he says: "At two in the afternoon, arrived at Fort Vancouver, and never did I feel more joyful to set my feet on shore, where I expected to find a hospitable people and the comforts of life. Doct. J. McLoughlin, a chief factor and superintendent of this fort and of the business of the Company west of the Rocky Mountains, received me with many expressions of kindness, and invited me to make his residence my home for the Winter, and as long as it would suit my convenience. Never could such an invitation be more thankfully received." On page $15^{8}$ he says: "Here, [Fort Vancouver] by the kind invitation of Dr. McLoughlin, and welcomed by the other gentlemen of the Hudson Bay Company, I took up my residence for the winter." And on page 263 he says: "Monday, I Ith April [1836]. Having made arrangements to leave this place on

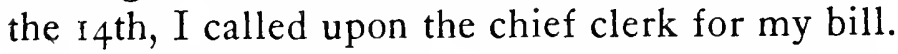
He said the Company had made no bill against me, but felt a pleasure in gratuitously conferring all they have done for the benefit of the object in which I am engaged. In justice to my own feel- 
ings, and in gratitude to the Honorable Company, I would bear testimony to their consistent politeness and generosity; and while I do this, I would express my anxiety for their salvation, and that they may be rewarded in spiritual blessings. In addition to the civilities I had received as a guest, I had drawn upon their store for clothing, for goods to pay my Indians, whom I had employed to convey me in canoes, in my various journeyings, hundreds of miles; to pay my guides and interpreters; and have drawn upon their provision store for the support of these men while in my employ."

In 1836 Dr. Marcus Whitman came to Oregon. With him came his wife, Rev. Henry H. Spalding and wife, and W. H. Gray, a layman. They arrived at Fort Vancouver September I, 1836. Here they were most hospitably entertained by Dr. McLoughlin and the other gentlemen of the Hudson's Bay Company, and all necessary and convenient assistance to these missionaries was freely given. When these missionaries arrived at $V$ ancouver, they had hardly more than the clothes they had on. They concluded to locate one mission near Waiilatpu, near the present city of Walla Walla, Washington; and another at Lapwai, near the present city of Lewiston, Idaho. Mrs. Whitman and Mrs. Spalding remained at Fort Vancouver for several months, while their husbands and Gray were erecting the necessary houses at the Missions.

Methodist Missions and Missionaries.

With Wyeth's second expedition, in 1834 , came the first Methodist missionaries: Rev. Jason Lee, 
Rev. Daniel Lee, his nephew, and the following laymen: Cyrus Shepard, a teacher; P. L. Edwards, a teacher; and a man named Walker. They arrived at Fort Vancouver September 17, 1834. They were also hospitably received by Dr. McLoughlin, and treated with every consideration and kindness. On Dr. McLoughlin's invitation Jason Lee preached at Fort Vancouver. Boats and men were furnished by Dr. McLoughlin to the missionaries to explore the country and select a proper place for the establishment of their Mission. In the McLoughlin Document, he says: "In 1834, Messrs. Jason and Daniel Lee, and Messrs. Walker and P. L. Edwards came with Mr. Wyeth to establish a Mission in the Flat-head country. I observed to them that it was too dangerous for them to establish a Mission [there]; that to do good to the Indians, they must establish themselves where they could collect them around them; teach them first to cultivate the ground and live more comfortably than they do by hunting, and as they do this,' teach them religion; that the Willamette afforded them a fine field, and that they ought to go there, and they would get the same assistance as the settlers. They followed my advice and went to the Willamette."

Rev. Dr. H. K. Hines published a book in 1899 entitled, "Missionary History of the Pacific Northwest." While, as is to be expected, Dr. Hines' book is biased in favor of the Methodist missionaries, and Jason Lee is his hero, nevertheless, he has endeavored to be fair and just to all. In this "Missionary History," page 92, Dr. Hines 
says: "It was no accident, nor, yet, was it any influence that Dr. McLoughlin or any other man or men had over him [Jason Lee] that determined his choice [of a site for the Mission]. It was his own clear and comprehensive statesmanship. Mr. Lee was not a man of hasty impulse. . . . This nature did not play him false in the selection of the site of his Mission." And on pages 452, 453, he says: "Some writers have believed, or affected to believe, that the advice of Dr. McLoughlin both to Mr. Lee in 1834 , and to the missionaries of the American Board in 1836 , was for the purpose of pushing them to one side, and putting them out of the way of the Hudson's Bay Company, so that they could not interfere with its purposes, nor put any obstacle in the way of the ultimate British occupancy of Oregon. Such writers give little credit to the astuteness of Dr. McLoughlin, or to the intelligence and independence of the missionaries of the American Board. Had such been the purpose of Dr. McLoughlin, or hàd he been a man capable of devising a course of action so adverse to the purposes for which his guests were in the country, he certainly would not have advised them to establish their work in the very centers of the great region open to their choice. This he did, as we believe, honestly and honorably."

Jason Lee selected, as the original site of the Methodist Mission,-a place on French Prairie, about ten miles north of the present city of Salem. When he and his party were ready to leave for their new home, Dr. McLoughlin placed at their disposal a boat and crew to transport the mission 
goods from the May Dacre, Wyeth's vessel, on which their goods had come, to the new Mission. He loaned them seven oxen, one bull, and seven cows with their calves. The moving of these goods and cattle to the Mission required several days. $\mathrm{He}$ also provided and manned a boat to convey the missionaries, personally. In his diary, Jason Lee says: "After dinner embarked in one of the Company's boats, kindly manned for us by Dr. McLoughlin, who has treated us with the utmost attention, politeness and liberality." 11

March I, I836, Dr. McLoughlin and the other officers of the Hudson's Bay Company, all British subjects, sent to Jason Lee, for the benefit of the Methodist Mission, a voluntary gift of one hundred and thirty dollars, accompanied by the following letter:

"ForT VANCOUVER, ist March, i 836.

"The Rev. Jason LeE,

\section{"Dear Sir:}

"I do myself the pleasure to hand you the enclosed subscription, which the gentlemen who have signed it request you will do them the favor to accept for the use of the Mission; and they pray our Heavenly Father, without whose assistance we can do nothing, that of his infinite mercy he will vouchsafe to bless and prosper your pious endeavors, and believe me to be, with esteem and regard, your sincere well-wisher and humble servant.

"JOHN MCLOUghLin." 12

\footnotetext{
${ }^{11}$ See Document D.

${ }^{12}$ Rev. Gustavus Hines, History of Oregon, p. 16.
} 
From its beginning, and for several years after, the successful maintenance of the Methodist Mission in Oregon was due to the friendly attitude and assistance of Dr. McLoughlin and of the other officers of the Hudson's Bay Company in Oregon. Without these the Mission must have ceased to exist. This applies also to the successful maintenance of all other missions in the Oregon Country in the same period of time. ${ }^{13}$

In May, 1837 , an addition to the Methodist Mission arrived at Vancouver. It consisted of eight adults and three children. Of these three were men, one of whom was Dr. Elijah White, the Mission physician; five were women, one of whom was Anna Maria Pittman, whom Jason Lee soon married. In September, 1837, the ship Sumatra arrived at Fort Vancouver loaded with goods for the Methodist Mission. The Sumatra also brought four more missionaries, two men, two women, and three children. Rev. David Leslie and wife were two of these missionaries. All these missionaries were entertained by Dr. McLoughlin, and provided with comfortable quarters at Fort Vancouver.

In March, 1838, Rev. Jason Lee left for the Eastern States, overland, on business for the Mission. His wife died June 26,1838 , three weeks after the birth and death of their son. Immediately on her death Dr. McLoughlin sent an express to overtake and tell Jason Lee of these sad events. The express reached Jason Lee about September I, 1838, at Pawnee Mission, near Westport, Missouri. ${ }^{14}$ From this act alone could any-

\footnotetext{
${ }^{18}$ Dr. H. K. Hines, Missionary History, p. 90.
} 
one doubt that Dr. McLoughlin was a sympathetic, kind, thoughtful, and considerate man? Or think that Jason Lee would ever forget? Later, in $1838 \mathrm{Dr}$. McLoughlin made a trip to London, returning to Fort Vancouver in 1839 .

While Jason Lee was on this trip to the Eastern States, the Missionary Board was induced to raise $\$ 42,000$ to provide for sending thirty-six adults, and sixteen children, and a cargo of goods and supplies, on the ship Lausanne, to Oregon for the Methodist Mission. Among these new missionaries were Rev. Alvan F. Waller, Rev. Gustavus Hines, and George Abernethy, a lay member, who was to be steward of the Mission and to have charge of all its secular affairs. This party of missionaries, who came on the Lausanne, are often referred to as "The great re-inforcement." The Lausanne, with its precious and valuable cargoes, arrived at Fort Vancouver June 1, i840. As soon as Dr. McLoughlin knew of her arrival in the Columbia River, he sent fresh bread, butter, milk, and vegetables for the passengers and crew. At Fort Vancouver he supplied rooms and provisions for the whole missionary party, about fifty-three people. This party remained as his guests, accepting his hospitality, for about two weeks. ${ }^{15}$ Shortly after some of this missionary party were endeavoring to take for themselves Dr. McLoughlin's land claim at Oregon City. The Lausanne was the last missionary vessel to come to Oregon.

Why this large addition to the Oregon Mission,

16 Rer. Gustavus Hines, History of the Oregon Missions, Pp. 31, 32; Dr. H. K. Hines, Missionary History, p. 156.

${ }^{15}$ Lee and Frost's Ten Years in Oregon, pp. 225, 226. 
and these quantities of supplies, were sent, and this great expense incurred, has never been satisfactorily explained. It seems to have been the result of unusual, but ill-directed, religious fervor and zeal. The Methodist Oregon Mission was then, so far as converting the Indians, a failure. It was not the fault of the early missionaries. Until i 840 they labored hard and zealously. The Indians would not be converted, or, if converted, stay converted. Their numbers had been greatly reduced by the epidemics of $1829-32$, and the numbers were still being rapidly reduced. And why the necessity of such secular business as a part of a mission to convert Indians to Christianity? ${ }^{10}$ The failure to convert the Indians was because they were Indians. Their language was simple and related almost wholly to material things. They had no ethical, no spiritual words. They had no need for such. They had no religion of their own, worthy of the name, to be substituted for a better or a higher one. They had no religious instincts, no religious tendencies, no religious traditions. The male Indians would not perform manual labor - that was for women and slaves. The religion of Christ and the religion of Work go hand in hand.

Rev. Dr. H. K. Hines, in his Missionary History, after setting forth certain traits of the Indians and the failures of the Methodist missionaries to convert them, says (p. 402): "So on the Northwest Coast. The course and growth of a history whose beginnings cannot be discovered had

\footnotetext{
${ }^{10}$ See Documents $\mathrm{E}$ and $\mathrm{F}$.
} 
ended only in the production of the degraded tribes among whom the most consecrated and ablest missionary apostleship the Church of Christ had sent out for centuries made almost superhuman efforts to plant the seed of the 'eternal life.' As a people they gave no fruitful response." And, on page 476, he says: "Indeed, after Dr. Whitman rehabilitated his mission in the autumn of 1843 , the work of that station lost much of its character as an Indian mission. It became rather a resting place and trading post, where the successive immigrations of $1844^{-} 45^{-}-46$ and ' 47 halted for a little recuperation after their long and weary journey, before they passed forward to the Willamette. This was inevitable." And on page $478 \mathrm{Dr}$. Hines says that Dr. McLoughlin "advised Dr. Whitman to remove from among the Cayuses, as he believed not only that he could no longer be useful to them, but that his life was in danger if he remained among them."

J. Quinn Thornton in his "History of the Provisional Government of Oregon," ${ }^{17}$ says: "In the autumn of 1840 there were in Oregon thirty-six American male settlers, twenty-five of whom had taken native women for their wives. There were also thirty-three American women, thirty-two children, thirteen lay members of the Protestant Missions, thirteen Methodist ministers, six Congregational ministers, three Jesuit priests, and sixty Canadian-French, making an aggregate of one hundred and thirty-six Americans, and sixty-three Canadian-French [including the priests in the lat-

\footnotetext{
${ }^{17}$ Transactions Oregon Pioneer Association for 1875, p. 45.
} 
ter class] having no connection as employées of the Hudson's Bay Company. [This estimate includes the missionaries who arrived on the Lausanne.] I have said that the population outside of the Hudson's Bay Company increased slowly. How much so, will be seen by the fact that up to the beginning of the year 1842 , there were in Oregon no more than twenty-one Protestant ministers, three Jesuit priests, fifteen lay members of Protestant churches, thirty-four white women, thirty-two white children, thirty-four American settlers, twenty-five of whom had native wives. The total American population will thus be seen to have been no more than one hundred and thirty-nine." (This was prior to the arrival of the immigration of 1842 .)

In his Missionary History Rev. Dr. Hines says (page 249) that in 1841 and 1842 , prior to the arrival of the immigration of 1842 , the Oregon Methodist Mission "comprised nearly all the American citizens of the country." And on page 239 he says: "Up to 1840 it [the Methodist Mission] had been entirely an Indian Mission. After that date it began to take on the character of an American colony, though it did not lay aside its missionary character or purpose." He also says that in 1840 there were only nine Methodist ministers in the Oregon mission. Some of the lay members, of which J. L. Parrish was one, became ministers, which probably accounts for the difference in the estimates of Thornton and of Dr. Hines. In the summer of 1843 Rev. Jason Lee was removed, summarily, as Superintendent of the Oregon Methodist Mission by the Missionary 


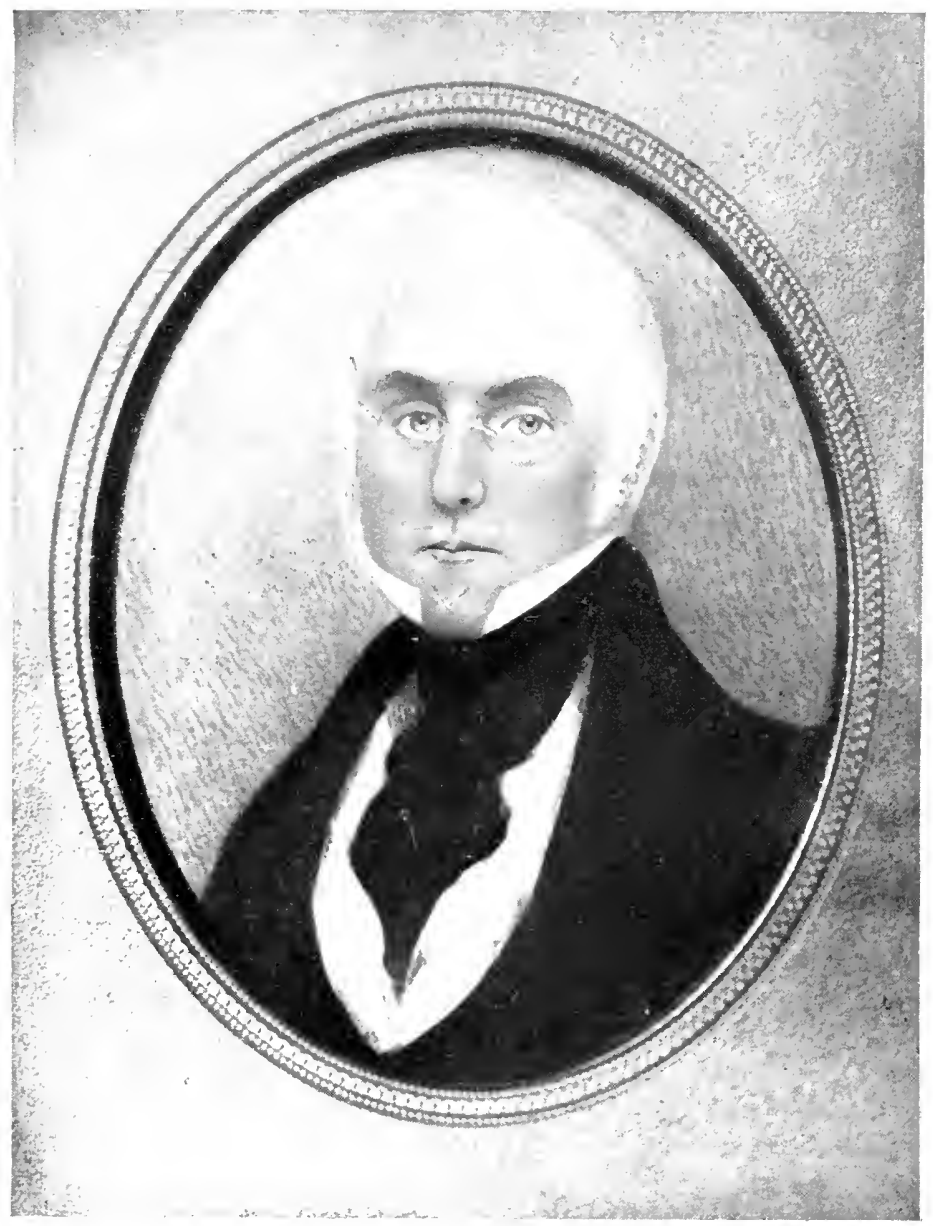

DR. JOHN MCLOUGHLiN

Taken from a miniature of Dr. Fohn 14 Loughlin painted on izory. This

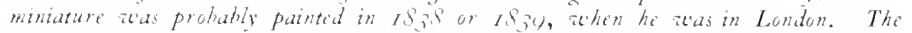

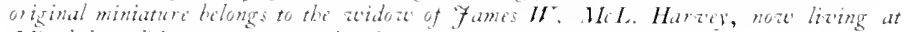
Whrahel, California. Her hustand atas a gramdson of Dr. 1h Loughlin. 

Board in New York, and Rev. George Gary was appointed in his place, with plenary powers to close the Mission, if he should so elect. He closed the Mission in 1844 .

When the Lausanne arrived June I, I840, Dr. McLoughlin's power and fortunes were almost at their highest point. During his residence of sixteen years in the Oregon Country he had established the business of his Company beyond all question, and to the entire satisfaction of its board of directors. The Indians were peaceable and were friendly and obedient to him and to his Company. He was respected and liked by all its officers, servants, and employées. With them he was supreme in every way, without jealousy and without insubordination. He had become, for those days, a rich man, his salary was twelve thousand dollars a year, and his expenses were comparatively small. He was then fifty-six years old. He had prepared to end his days in Oregon on his land claim. His children had reached the age of manhood and womanhood. Few men at his age have a pleasanter, or more reasonable expectation of future happiness than he then had.

The half-tone portrait of Dr. McLoughlin, shown facing page 62 , was taken from a miniature, painted on ivory, in London, probably when he was in London in $1838-9$. It portrays $\mathrm{Dr}$. McLoughlin as he was in his happy days. This miniature now belongs to the widow of James $W$. McL. Harvey, who was a grandson of Dr. McLoughlin. It was kindly loaned by her so that the half-tone could be made for use in this address. 
Provisional Government.

For convenience I shall tell of the Provisional Government of Oregon before I speak concerning Dr. McLoughlin's land claim.

About I841, owing to the death of Ewing Young, intestate, leaving a valuable estate and no heirs, the residents of the Oregon Country in the Willamette Valley saw the necessity of some form of government until the Oregon Question should be finally settled. As under the Conventions of 18 I 8 and 1827 there was joint-occupancy between the United States and Great Britain, the Oregon Country was without any laws in force. It was commonly understood, at that time, that most of the Americans in Oregon favored a provisional organization-one which would exist until the laws of the United States should be extended over the Oregon Country. It was also commonly understood that the British residents in Oregon opposed a provisional government, as it might interfere with their allegiance to Great Britain. As there was a joint-occupancy, and the British were legally on an equality with the Americans, each had equal rights in the matter. February 17 and I8, 184I, a meeting of the inhabitants was held at the Methodist Mission. Although attempts were then made to form a government, several officers were appointed, and a committee appointed for framing a constitution and a code of laws, the movement failed. The matter lay dormant until the spring of 1843 . The immigration of I 842 , although small, and although about half of them went to California in the spring of 1843 , materially increased the strength of the Americans in Oregon. 
After several preliminary meetings had been held, the momentous meeting of May 2, I843, was held at Champoeg, when, by the vote of $5^{2}$ in favor and 50 against, the Provisional Government of Oregon was created. Certain officers were elected and a legislative committee of six was appointed, the latter to report July 5, I843. On the latter day most of the report was adopted, an executive committee of three persons, David Hill, Alanson Beers, and Joseph Gale, was chosen in place of a governor, and Oregon had at least a de facto government, which, with some changes, continued until Oregon had a Territorial Government, in 1849. George Abernethy, the steward of the Methodist Mission, was elected Governor in 1845 , and by re-election continued to be Governor until the arrival of Gen. Joseph Lane, the first Territorial Governor, in March, I849. The Mission Party was one of the strongest and most influential political parties in Oregon until the election of Governor Joseph Lane as Delegate to Congress, June 2, $1851 .{ }^{18}$ At the time of the formation of the Provisional Government, the residents of Oregon seem to have been divided into three classes, or parties: one favored a provisional government, favorable to the United States; another favored an independent government, which would be neutral as between the United States and Great Britain; the third believed that matters should remain in statu quo. For some reason Jason Lee and George Abernethy, and some others of the Methodist missionaries, seem originally to have belonged to or

${ }^{18}$ History of Oregon by Rev. H. K. Hines, D.D., pp. 166, 167. 
to have favored the third class. ${ }^{19}$ In the "Political History of Oregon" by J. Henry Brown, he says (page 95) that at a meeting of the committee held at Oregon City, in March, I843, "Rev. Jason Lee and $\mathrm{Mr}$. Abernethy were disposed to ridicule the proposed organization [i.e., the Provisional Government] as foolish and unnecessary, and repeated some anecdotes to illustrate their meaning."

Dr. McLoughlin was not originally in favor of the Provisional Government. It was openly and avowedly advocated as being in favor of the United States, and against Great Britain. Once started, without a trial, no one could know where it would end. Already some of the Americans had denounced the Hudson's Bay Company and Dr. McLoughlin, and had made threats against the property of the Company. His loan of cattle had been misunderstood and denounced. Some of the Americans seemed not to be aware that the Hudson's Bay Company was lawfully in the Oregon Country, under the Conventions for joint-occupancy. To aid or to assist the establishment of a government, owing exclusive allegiance to the United States, would be, or might be disloyalty by Dr. McLoughlin to his Country and be injurious or fatal to his Company in Oregon. By the constitution or compact of the Provisional Government, as established in $18_{43}$, each officer was required to take an oath or affirmation "to support the laws of the territory," without qualification. There was, too, his land claim at Oregon City, which the land laws of the Provisional Government, as estab-

${ }^{19}$ Gray's History of Oregon, pp. 268, 269. 
lished, sought to deprive Dr. McLoughlin of, and to give, at least a part of it, to the Methodist Mission. About the status of his land claim I shall presently explain. There was, also, the cry of "54-40 or fight" and the chance of war over the Oregon Country between the United States and Great Britain. Dr. McLoughlin appealed to the directors of his Company for protection to their property, but none came. In June, 1844 , he received an answer from his Company that it could not obtain protection from the British Government, and that the Hudson's Bay Company must protect itself the best it could. The fortifications at Fort Vancouver were strengthened. There was threatened trouble in the air. It looked as though there might be war in Oregon.

In 1845 the Provisional Government attempted to extend its jurisdiction north of the Columbia River. It became a question of acquiescence or actual opposition by the Hudson's Bay Company. Jesse Applegate, one of the best and noblest of Oregon's pioneers, who was a member of the Provisional Legislature and one of a committee, privately interviewed Dr. McLoughlin. After consulting with James Douglas, his chief assistant, a compromise was finally agreed to by which the Hudson's Bay Company would be taxed only on goods sold to the settlers. August I 5, I 845 , the Hudson's Bay Company, with all the British residents, became parties to the Oregon Provisional Government. The oath of office as provided by the compact of 1843 had been changed by what is called the "Organic Act" of the Provisional Gov- 
ernment, adopted by the people, by popular vote, July 26,1845 . As so amended the oath of office required each officer to swear that he would "support the organic laws of the Provisional Government of Oregon, so far as said organic laws are consistent with my duties as a citizen of the United States, or a subject of Great Britain." The land law of 1843 was also changed by said vote of the people, July 26 , 1845 , by which the objectionable features, so far as Dr. McLoughlin's land claim at Oregon City was concerned, were largely eliminated. Under the circumstances joining the Provisional Government was a good and wise move on the part of Dr. McLoughlin. But he was severely criticized therefor by his Company. Unknown to Dr. McLoughlin, there was then a large British fleet of war in the Pacific Ocean.

A few days after Dr. McLoughlin, for himself and his Company, had thus joined the Provisional Government, he was surprised by the arrival from Puget Sound of Lieut. Wm. Peel, son of Sir Robert Peel, and Captain Park of the Royal Marines, with a letter from Captain Gordon, commanding the British 5o-gun ship-of-war America, then in Puget Sound, and also a letter from Admiral Seymour, commanding the British fleet, that "firm protection" would be given British subjects in Oregon. Subsequently the British war sloop, Modeste, 18 guns, arrived at Fort Vancouver, where she remained until the boundary treaty of 1846 was entered into. ${ }^{20}$

20 "Narrative of Dr. McLoughlin" published in the Quarterly of the Oregon Historical Society, June, 1900. 
Immigration of 1842 .

In 1842 came the immigration of that year, which is now counted the first real immigration of American settlers to Oregon. I believe, however, that the immigration of 1843 should be called the first immigration of Oregon home-builders. But that question is not material in this address. The number of the immigrants of 1842 has been variously estimated, but, after a somewhat careful examination of the matter, I believe there were all told about one hundred and twenty-five. Of this number about fifty-five were men over eighteen years of age. These immigrants left their wagons at Fort Hall and used pack horses. They came from The Dalles to Oregon City, overland, by the Indian trail which passed near Mt. Hood. ${ }^{21}$

Many of the immigrants of 1842 were disappointed in Oregon. The country was then very new, and they became discontented. Dr. McLoughlin engaged many to labor at fair wages, and furnished goods on credit to those who could not make immediate payment. Some of them were of a roving or adventurous class, ever seeking new places. In the spring of 1843 nearly half of them went to California, leaving on their journey May 30, from Champoeg. Dr. McLoughlin furnished these emigrants to California with supplies, upon their promise to pay for the same to W. G. Rae, the Hudson's Bay Company's agent at Yerba Buena (now San Francisco). Most of them did not pay, and Dr. McLoughlin personally assumed the payment of this indebtedness.

\footnotetext{
${ }^{21}$ Address of Medorum Crawford, in 1881. See Transactions of the Oregon Pioneer Association for 1881, p. 14.
} 
Immigration of 1843 .

In 1843 came the first great immigration to Oregon. As if by a common impulse, and without preconcert, the immigrants met at Independence, Missouri, leaving there for Oregon, May 20, I 843. Peter H. Burnett, afterwards a Chief Justice of the Oregon Provisional Government, and the first Governor of the State of California, was the first Captain. J. W. Nesmith, afterwards United States Senator from Oregon, was Orderly Sergeant. About eight hundred and seventy-five men, women, and children composed this immigration. Of these there were two hundred and ninety-five men, over the age of sixteen years. In this immigration were my grandfather, John Holman, and his son, Daniel S. Holman, then nearly twenty-one years old.

After first arriving at the Columbia River, they straggled and struggled along the Columbia River to Fort Vancouver - a few driving cattle, going overland by the Indian trail from near The Dalles to Oregon City. There was not then any way to take wagons by land from The Dalles to the Willamette Valley. A few of the immigrants went down the Columbia River to The Dalles in boats. In one of these parties three persons were drowned by the capsizing of boats. The rest of the immigrants went to The Dalles overland with their wagons. From The Dalles to the Cascades some of them went by boats, others went on rafts, which they constructed. There was great difficulty in going from the Upper Cascades to the Lower Cascades. The rafts could not be taken over the rapids. 
It took about two weeks to cut a trail around the Cascades. The rains set in. The position of the immigrants was desperate. Some did not arrive at Fort Vancouver until about Christmas. They had not anticipated such hardships and privations as they were then suffering. Few had sufficient food or raiment, many were absolutely destitute. Dr. McLoughlin sent supplies to be sold to those who were able, and to those who could not buy, the supplies were furnished on credit, or given to them. He furnished boats to carry them from the Cascades to Fort Vancouver. He caused the sick to be attended to, and nursed at the Company's hospital at Fort Vancouver. He furnished them every assistance as long as they required it. Time will not permit me to go into the details.

When the immigrants of 1843 were thus coming along the Columbia River, some helpless and almost hopeless, there was a plot by the Indians to massacre these Americans. It was prevented by Dr. McLoughlin. The effect of such a massacre would have been tremendous. It would have, probably, prevented the further settlement of Oregon for years. Had the United States sent troops to punish the Indians in the disputed Oregon Country, it would have almost certainly precipitated a war with Great Britain.

In presenting the McLoughlin Document to the Oregon Pioneer Society, in I88o, Col. J. W. Nesmith said: "I had intended reading it to you as a part of my address, but, having already trespassed too long upon your patience, I shall hand the document to the secretary of the Society, with 
my endorsement of the truth of all its statements that came within my own knowledge. . . . I desire to say, what I believe all old pioneers will agree to, that the statements of this paper furnished a . . complete vindication of Dr. McLoughlin's acts and conduct, and that the integrity of his narrative cannot be impeached by any honest testimony." In the McLoughlin Document Dr. McLoughlin says: "In 1843 , about 800 immigrants arrived from the States. I saw by the looks of the Indians that they were excited, and I watched them. As the first stragglers were arriving at Vancouver in canoes, and I was standing on the bank, nearer the water there was a group of ten or twelve Indians. One of them bawled out to his companions, 'It is good for us to kill these Bostons [Americans].' Struck with the excitement I had seen in the countenances of the Indians since they had heard the report of the immigration coming, I felt certain they were inclined to mischief, and that he spoke thus loud as a feeler to sound me, and take their measures accordingly. I immediately rushed on them with my cane, calling out at the same time, 'Who is the dog that says it is a good thing to kill the Bostons?' The fellow, trembling, excused himself, 'I spoke without meaning harm, but The Dalles Indians say so.' 'Well,' said I, 'The Dalles Indians are dogs for saying so, and you also,' and left him, as, if I had remained longer it would have had a bad effect. I had done enough to convince them I would not allow them to do wrong to the immigrants with impunity. From this Indian saying, 
in the way he did, that The Dalles Indians said it was good to kill the Bostons, I felt it my duty to do all I could to avert so horrid a deed.

"Mr. P. L. Edwards, whom I mentioned, came in 1834 , with the Messrs. Lee, and left in 1838 , and sent me a letter by Gen. McCarver, stating he had given a letter of introduction to me to $\mathrm{P}$. $\mathrm{H}$. Burnett, Esq. I immediately formed my plan and kept my knowledge of the horrid design of the Indians secret, as I felt certain that if the Americans knew it, these men acting independently of each other, would be at once for fighting, which would lead to their total destruction, and I sent two (2) boats with provisions to meet them; sent provisions to Mr. Burnett, and a large quantity of provisions for sale to those who would purchase, and to be given to those who had not the means, being confident that the fright I had given (as I already stated) the Indians who said it was a good thing to kill the Bostons was known at The Dalles before our boats were there, and that the presence of the Hudson's Bay Company people, and the assistance they afforded the immigrants, would deter the Indians from doing them any wrong, and I am happy to be able to say that I entirely succeeded."

Dr. McLoughlin then says, in this Document, that about a month after this incident he told Dr. Marcus Whitman what had occurred. Dr. McLoughlin thought the trouble might have been started by some Iroquois Indian in the employ of the Hudson's Bay Company, and Dr. McLoughlin was anxious "to find that rascal out to punish him 
as an example to deter others." Dr. Whitman then said that he had known of this trouble among the Indians for about two years, although he had said nothing to Dr. McLoughlin about it, and that the trouble was caused by a Shawnee Indian named Tom Hill, who is said to have been educated at Dartmouth College. He had urged the Indians to allow no Americans to settle on their lands, as the Americans had driven out the Shawnees, and that the Indians about Walla Walla said the Cayuses were inclined to follow the advice by killing the immigrants who first came. It will be remembered that the Cayuses were the Indians who caused the Whitman massacre in 1847 . Dr. McLoughlin, in this Document, then says that he believes the Indians would have killed these immigrants of 1843 but for the decided and cautious manner in which he acted. Dr. McLoughlin continues: "And the reason the Indian made use of the expression he did was because I punished the murderers of the Smith party; and, before acting, they wanted to know how I would treat them. And most certainly if I had not been most anxious for the safety of the immigrants, and to discharge to them the duties of a Christian, my ear would not have caught so quickly the words, 'it is a good thing to kill these Bostons,' and acted as I did."

Then there was the question how these immigrants of 1843 should be provided for during the winter and until the next harvest. They had no implements, no seed. There was a crisis impending. Without waiting to be asked, Dr. McLoughlin gave credit, furnishing these immigrants with 
food and clothing for the present, and also farm implements and seed-wheat to begin their farming. He exacted no collateral, he gave time without interest. All this was against the rules of the Hudson's Bay Company. He made himself personally liable for all these debts. $\mathrm{He}$ also loaned these immigrants cattle, including cows, and also hogs.

Col. J. W. Nesmith, one of the immigrants of 1843 , in his address before the Oregon Pioneer Association in 1876 said: "Dr. John McLoughlin, then at the head of the Hudson's Bay Company, from his own private resources, rendered the new settlers much valuable aid by furnishing the destitute with food, clothing, and seed, waiting for his pay until they had a surplus to dispose of." Peter $\mathrm{H}$. Burnett, of whom I have already spoken, was one of the immigrants of 1843 . He started a town and called it Linnton, which was situated where the present town of Linnton is situated-eight miles north of Portland on the Willamette River, and about half way between Portland and Vancouver by water. He kept a journal of his travels, which was published, in part, in the New York Herald in 1844 . Part II of the History of Oregon by George Wilkes, published in $\mathrm{I} 845$, is largely taken from this journal. ${ }^{22}$ In this journal Burnett says: ${ }^{23}$ "On my arrival I was received with great kindness by Doctor McLoughlin and Mr. James Douglass, the second in command. They both tendered me the hospitalities of the fort, which offer, it is scarcely necessary to say,

\footnotetext{
${ }^{22}$ See Quarterly of the Oregon Historical Society, Vol. 3, pp. 398-426.

${ }^{23}$ Wilkes, History of Oregon, p. 95.
} 
I accepted willingly and with pleasure.

His hospitality is unbounded, and I will sum up all his qualities, by saying that he is beloved by all who know him. . . . The kindness of Dr. McLoughlin to this emigration has been very great. $\mathrm{He}$ furnished them with goods and provisions on credit, and such as were sick were sent to the Hospital free of expense, where they had the strict and careful attendance of Dr. Barclay, a skillful physician, and an excellent and humane man. The Chief Factor [Dr. McLoughlin] likewise lent the emigrants the Company's boats, to bring down such of the families and baggage as had been left at the Cascades by the advance guard of the expedition, which had preceded me; and he also furnished them with the facilities for crossing the river with their cattle, at Vancouver. Had it not been for the kindness of this excellent man, many of us would have suffered greatly. . . . It is certain that the Doctor himself has uniformly aided settlers, by supplying them with farming implements, and with seed-grain, as a loan, to be returned out of the succeeding crop. He even went so far as to lend them hogs, to be returned two or three years afterward, by their issue of the same age; to furnish oxen to break their ground, and cows to supply milk to their families. This certainly appears to me to be a very poor way to retard the settlement of the region, and to discourage adventurers who arrive in it."

In $1880 \mathrm{Mr}$. Burnett, then ex-Governor of California, wrote a book called "Recollections and 
Opinions of an Old Pioneer," so that we have his opinion of Dr. McLoughlin in 1843 contemporaneous with the events I speak of, and also his mature reflections thirty-seven years after that. On page 142 of this book Mr. Burnett says: "When we arrived in Oregon we were poor, and our teams were so much reduced as to be unfit for service until the next spring. Those of us who came by water from Walla Walla left our cattle there for the winter; and those who came by water from The Dalles left their cattle for the winter at that point. Even if our teams had been fit for use when we arrived, they would have been of no benefit to us, as we could not bring them to the Willamette Valley until the spring of 1844 . Pork was ten, and flour four cents a pound, and other provisions in proportion. These were high prices considering our scanty means and extra appetites. Had it not been for the generous kindness of the gentlemen in charge of the business of the Hudson's Bay Company, we should have suffered much greater privations. The Company furnished many of our immigrants with provisions, clothing, seed, and other necessaries on credit. This was done, in many instances, where the purchasers were known to be of doubtful credit. Many of our immigrants were unworthy of the favors they received, and only returned abuse for generosity."

Captain J. C. Fremont, afterwards Major-General, in the United States Army, was at Fort Vancouver when the immigrants of 1843 were arriving. On page I9I of the Report of his Second Exploring Expedition, he says: "I found many 
American emigrants at the fort; others had already crossed the river into their land of promise the Walahmette Valley. Others were daily arriving; and all of them had been furnished with shelter, so far as it could be afforded by the buildings connected with the establishment. Necessary clothing and provisions [the latter to be afterwards returned in kind from the produce of their labor] were also furnished. This friendly assistance was of very great value to the emigrants, whose families were otherwise exposed to much suffering in the winter rains which had now commenced, at the same time that they were in want of all the common necessaries of life."

\section{Immigration of 1844 .}

The immigration of 1844 was composed of about fourteen hundred persons. They suffered many hardships and many lost all, or a part of, their cattle, clothing, and goods. Most of these immigrants arrived late in the season. Snow began to fall before all arrived at their destinations. Boats were supplied free, and provisions, cattle, and seed-wheat were furnished them on credit by Dr. McLoughlin, as he had the immigrants of 1843. The supplies in Oregon had been nearly exhausted by the immigration of 1843 , although Dr. McLoughlin had urged the raising of grain and other supplies in anticipation of the coming of the immigration of 1844 . The available supply of clothing at Fort Vancouver had been practically exhausted before the arrival of the immigration of 1844 . 
John Minto, who is still living in Oregon, was one of the immigrants of $\mathrm{I} 844$. In his address presenting to the State of Oregon the portrait of Dr. John McLoughlin, which now hangs in the Senate Chamber, he said: "To the assistance given to the Immigrants of 1843 , as described by Col. Nesmith, I can add as an eyewitness, that those of I 844 received the loan of boats in which to descend the Columbia River from The Dalles (there being no road across the Cascades [mountains]); the hungry were fed, the sick cared for and nursed, and, not the least, was the fact that many of the employées of the Hudson's Bay Company followed the good Doctor in their treatment of the Americans. Especially was this the case in the settlement of retired Canadians who almost worshipped him."

Joseph Watt, the well-known enterprising pioneer of 1844 , who largely assisted in starting the first woolen mill in Oregon, in 1857 , in his "Recollections of Dr. John McLoughlin," published in the Transactions of the Oregon Pioneer Association of 1886 said (pages 24 and 25): "On the $13^{\text {th }}$ of November, 1844, a company of immigrants landed at Fort Vancouver, brought there on a bateau commanded by Joseph Hess, an immigrant of ' 43 . The boat belonged to the Hudson's Bay Company. Mr. Hess was entrusted with the boat for the purpose of bringing immigrants down the river. We had eaten the last of our provisions at our last camp, and were told by Hess that we could get plenty at the fort, with or without money;that the old Doctor never turned people away 
hungry. This made us feel quite comfortable, for there was not a dollar among us. As near as I can remember the company consisted of sixteen men, five women and four children. . . We were the first to arrive. . . . We soon found the Doctor in a small room he called his office. . . . He spoke of our being so late, and feared there would be considerable suffering before they could all be taken down the river, but should do all in his power until they reached their destination.

"We then made known to him our wants. We were all out of provisions. There was a small table in one corner of the room, at which he took a seat, and directed us to stand in a line - (there being so many of us the line reached nearly around the room) - and then told us the year before, and in fact previous years, he had furnished the people with all the provisions and clothing they wanted, but lately had established a trading house at Oregon City, where we could get supplies; but for immediate necessity he would supply provisions at the fort. Several of our party broke in, saying: 'Doctor, I have no money to pay you, and I don't know when or how I can pay you.' 'Tut, tut, never mind that; you can't suffer,' said the Doctor. He then commenced at the head man saying, 'Your name, if you please; how many in the family, and what do you desire?' Upon receiving an answer, the Doctor wrote an order, directing him where to go to have it filled; then called up the next man, and so on until we were all supplied. He told us the account of each man would be sent to Oregon City, and when we took a claim, and raised wheat, 
we could settle the account by delivering wheat at that place. Some few who came after us got clothing. Such was the case with every boat load, and all those who came by land down the trail. If he had said 'We have these supplies to sell for cash down,' I think we would have suffered.

When we started to Oregon, we were all prejudiced against the Hudson's Bay Company, and Dr. McLoughlin, being Chief Factor of the Company for Oregon, came in for a double share of that feeling. I think a great deal of this wàs caused by the reports of missionaries and adverse traders, imbuing us with a feeling that it was our mission to bring this country under the jurisdiction of the stars and stripes. But when we found him anxious to assist us, nervous at our situation in being so late, and doing so much without charge, letting us have of his store, and waiting without interest, until we could make a farm and pay him from the surplus products of such farm, the prejudice heretofore existing began to be rapidly allayed. We did not know that every dollar's worth of provisions, etc., he gave us, all advice and assistance in every shape was against the positive orders of the Hudson's Bay Company. . . . In this connection I am sorry to say that thousands of dollars virtually loaned by him to settlers at different times in those early days, was never paid, as an examination of his books and papers will amply testify."

\section{Immigration of 1845 .}

The immigration of 1845 numbered about three 
thousand persons. Many of them suffered more than the preceding immigrations. They also were assisted by Dr. McLoughlin as he had the immigrants of 1843 and 1844 . For this he was charged with disloyalty by one of the British spies then at Vancouver. Stephen Staats was one of the immigrants of 1845 . In his address before the Oregon Pioneer Association, in 1877, he said: "We reached Oregon City in thirteen days (overland) from The Dalles (two of which we were without food), and on our arrival, those of us in advance were kindly and hospitably received by old Dr. McLoughlin. He immediately furnished us with provisions, without money and without price, and extended to us favors which we were ever ready to reciprocate. I am not one of those who wish to cast reflections on the character of Dr. McLoughlin, or wish to impute to him anything wanting in the kindest feeling towards the immigrants of 1845 . For well do I know, that but for him, many would have been more embarrassed in making provision for the coming winter's necessities than they were. And I have yet to see the immigrant of $\mathrm{I} 845$, who, when speaking of the 'Old Man Doctor,' does not speak in high commendation of his actions towards the immigrants of that year." The wise, humane, and paternal foresight of Dr. McLoughlin was of great assistance to the immigrants of 1845. In the McLoughlin Document he says: "When the immigration of 1842 came, we had enough of breadstuffs in the country for one year, but as the immigrants reported that next season there would be a great immigration, it was evident, 
if there was not a proportionate increase of seed sown in 1843 and 1844 , there would be a famine in the country in 1845 , which would lead to trouble, as those that had families, to save them from starvation, would be obliged to have recourse to violence to get food for them. To avert this I freely supplied the immigrants of 1843 and I 844 with the necessary articles to open farms, and by these means avoided the evils. In short I afforded every assistance to the immigrants so long as they required it, and by management I kept peace in the country, and in some cases had to put up with a great deal."

The Quality of the Early Immigrants.

The early immigrants to Oregon were not mendicants nor tramps. It is true some of them were of a roving disposition; probably a few were of the improvident class. Most of them were forceful, strong men and women, physically and mentally; strong also in their Americanism, and filled with the racial instinct to follow the western course of Empire. They came to Oregon as home-builders. Many of them had their lineage from the pioneers who first settled the Atlantic Coast, particularly the southern part of it. Descendants of these pioneers had crossed the mountains and were the hardy and courageous pioneers of Kentucky and Tennessee in the early, perilous, and heroic days of Daniel Boone, John Sevier, George Rogers Clark, and James Robertson. The ancestors of some of these Oregon immigrants had taken part in the great war of the American Revolution on the At- 
lantic Coast, and had then assisted in upbuilding civilization in the Middle West. These forefathers had won the Middle West. These immigrants came to win Oregon. The grandfathers and fathers of some of them had taken part in the war of 1812 , and in the later Indian wars. A few of these immigrants were veterans of the war of 18 I 2 and of these Indian wars. There were immigrants who had taken active part in the troubles with the Mormons and had assisted in driving them out of Western Missouri. It was of this stock that parts of Missouri, and especially the western part of that state, had been then largely peopled, and many of these Oregon immigrants had settled' there temporarily before coming to Oregon. " A great majority of the immigrants to Oregon from I 843 to 1846 , inclusive, and of some of the later immigrants, were from the Southern States. They, and their ancestors for many generations, had been born and brought up in the South. Most of them had the good qualities and were of the high type of American citizenship characteristic of the white people of the South. They were mostly plain people, but they and their ancestry were of good class. Theirs was an inheritance of indomitable will, high courage, and noble purposes. Their ancestors had conquered, settled, and upbuilded the country from the seaboards of Virginia and the Carolinas to the Mississippi River. ${ }^{24}$ Oregon was another land to conquer, to settle, and to upbuild. There were also in these early immigrations a number of men and women, descendants of

${ }^{24}$ See Theodore Roosevelt's Winning of the West. 
the sturdy peoples who settled in New England, and in other Northern States. There were a few men who were attracted to Oregon by the love of adventure incident to the journey and to the settlement of a new country. There were also a few men, born outside of the United States, who allied themselves with the Americans, and became identified with the Americans in Oregon, and subsequently were admitted as citizens of the United States.

The places these immigrants left to come to Oregon, although some of these places were comparatively new, were mostly over-supplied with unsold agricultural products - unsalable for want of markets. The early books and pamphlets on Oregon and the stirring speeches of Oregon enthusiasts, who had never been to Oregon, pictured Oregon as the traditional land of plenty and of "milk and honey." There was, too, an abiding faith in the future, a certain improvidence born of strong manhood and womanhood. They were filled with confidence in their ability to conquer all troubles and overcome all difficulties. They did not think of failure - they intended to succeed. Then, too, the journey was longer and more arduous than they had anticipated. Their greatest dangers and troubles were after they had entered the Oregon Country and reached the Columbia River. All east of that river, with its hardships, was comfortable compared with the troubles and dangers to come. They did not come seeking, nor did they seek charity or alms. The true, honest, brave-hearted immigrants wished to pay for what they obtained, and did as soon as they were able 
to do so. They were met by conditions which they could not, or did not, foresee. Dr. John McLoughlin, with his great, manly prescience, appreciated all this. He sold provisions and clothing to those who could pay; equally, he sold on credit, to those who could not, without references, without collaterals. He understood the quality of most of these pioneers - he was unfortunately in error as to some of them. It was not charity on the part of Dr. McLoughlin, it was the exercise of that great quality, which he possessed in an extraordinary degree-humanity.

I regret to say that a few of these early immigrants, at times, without cause, were rude to Dr. McLoughlin and abusive of his Company, and of his Country. Some of these did not care-others had been prejudiced by false information, which they had read or heard before they left their homes, or on the way to Oregon. Some, I still more regret to say, accepted the credit extended to them by Dr. McLoughlin, and never paid. But the payment to the Hudson's Bay Company of these bad debts was assumed by Dr. McLoughlin. The aggregate amount is not definitely known, for Dr. McLoughlin suffered, in many ways, in silence. But it was a very large sum. Those who paid in full could not requite his kindness to them.

The real Oregon pioneers are these overland immigrants who came to Oregon prior to 1847 . The immigrants of 1846 were a long way on their journey to Oregon when the Boundary Treaty was made. They left on their journey early in May, I.846. This treaty was signed at Washington, June 
15, 1846. The proclamation by the President of the Treaty and of its ratification by the two countries is dated August 5, I846. The immigrants of I 846 did not know that the Treaty had been made, signed, or confirmed until after their arrival in Oregon. The news that the Treaty had been signed came by a sailing vessel, and did not reach Oregon until November, I846. ${ }^{25}$ The distance traveled by the immigrants to Oregon, from the rendezvous at Independence, Missouri, to Oregon City, was about two thousand miles. The usual time in making this journey was between five and six months. Ox-teams were used almost exclusively. It was thought that the use of horses for teams was impracticable. It was feared there would be insufficient food for such horses, on the way, as the numbers would be large. It would be necessary to keep these horses shod for pulling the heavily loaded wagons. Many horses were brought which were used for riding, rounding-up cattle, and in hunting. There were practical difficulties in caring for, and feeding horses at night. Horses had to be "staked" at night, cattle would graze at large. Horses were liable to be stampeded and be lost or be stolen by the Indians. Oxen were much cheaper than horses. It would require at least four horses to a wagon. It was desirable to have cows to furnish milk on the way, especially for the children. Good cattle were scarce in Oregon and it was desirable to take cows and bulls for breeding purposes, and other cattle for beef. Many of these immigrants brought cat-

\footnotetext{
${ }^{25}$ Oregon Spectator, November 12, 1846.
} 
tle with them in addition to their ox-teams. These cattle and ox-teams could not travel as fast as horses and the speed of the latter necessarily would be kept to that of the ox-teams. Should oxen be lost or die, their places could be taken by cattle or even by cows. This was not infrequently done.

These early immigrants all came to, or started for Oregon, overland, in the time of jointoccupancy. They were not encouraged, helped, nor protected by the Government in coming to Oregon. There were no United States troops in the Oregon Country, or near the immigrant trail prior to 1849 . The Cayuse Indian war of I $847-8$ was carried on by the Oregon Provisional Government alone, without assistance from the United States Government. This war was fought wholly by volunteers from the Willamette Valley. The coming of these early immigrants assisted to hold Oregon for the United States, and greatly contributed to the settlement of the Oregon Question. They relied on themselves but they believed that their Country would protect its own in Oregon. Their rights and courage could not be ignored. There was no one man who saved Oregon. If any persons saved Oregon, they were these immigrants from 1843 to and including 1846 . There is not a true American who does not take pride in the daring of these pioneers and in what they accomplished in coming to Oregon. Whatever some of them may have lacked, in certain qualities, and in spite of the bad treatment, by some of them, of Dr. McLoughlin, the patriotism and courage of most of them were of 
the highest types. This great movement of immigrants to Oregon from 1843 to 1846 , inclusive, may not, even now, be thoroughly understood nor explained but it is fully appreciated. With all its dangers and hardships, with all its mystery and simplicity, and its commonplaces, it stands today one of the most daring colonizing movements for, and the most remarkable, interesting, and romantic story of the settlement and upbuilding of any part of the continents of the two Americas.

It must be borne in mind that all these aids by Dr. McLoughlin to the immigrants of 1843 , and succeeding years, were after some of the Methodist missionaries had attempted to take his land claim, and succeeded in part. The history of these transactions I shall presently relate. And did the secular department of the Methodist Mission assist these early pioneers in any way similar to what was done by Dr. McLoughlin? If so, I have found no trace nor record of it. Undoubtedly Methodist missionaries, individually, did many kindly acts to destitute immigrants. Had Dr. McLoughlin acted with the supineness of the Methodist Mission toward the immigrants of 1843,1844 , and 1845 , and especially that of 1843 , the consequences would have been terrible. Leaving out the probability of massacres by the Indians, many immigrants would have died from starvation, exposure and lack of clothing along the Columbia River, or after their arrival in the Willamette Valley. It is true Fort Vancouver might have been captured and destroyed. That would have given no permanent relief. That would probably have been the 
beginning of a war between the United States and Great Britain. Even without a war the settlement of Oregon would have been delayed for many years. And all of the Oregon Country north of the Columbia River might have been lost to the United States.

Sir George Simpson, the Governor in Chief of the Hudson's Bay Company, severely criticized Dr. McLoughlin for his assistance to the immigrants. There was an acrimonious correspondence between them on the subject. As I am informed, it was in this correspondence, which I have not seen, that Dr. McLoughlin had written the Hudson's Bay Company that he had furnished these supplies to the immigrants, saying that, as a man of common humanity, it was not possible for him to do otherwise than as he did; that he had only done what anyone truly a man would have done. That it was then insisted by Governor Simpson that Dr. McLoughlin should no longer assist any needy immigrants, or help any other immigrants. To this Dr. McLoughlin made the noble reply, "Gentlemen, if such is your order, I will serve you no longer." This reply was made by $\mathrm{Dr}$. McLoughlin - the only question is as to the exact time and place it was made.

The Resignation of Dr. John McLoughlin.

In 1845 Dr. McLoughlin sent in his resignation to the Hudson's Bay Company. Its rules required one year's notice before an officer could resign. His resignation took effect before the immigration of 1846 arrived. As this address relates to 
Dr. McLoughlin, and only incidentally to the Oregon Pioneers, I shall not go into details about the immigrations succeeding that of 1845 . Dr. McLoughlin kept a store and lived at Oregon City after his resignation. To the immigrants of 1846 and after, and to others, as long as he was in business there, he continued, as far as he was able, the same hospitality and the same good and humane treatment he had exercised when Chief Factor at Fort Vancouver. The Barlow road was built in 1846 and the immigrants of that year and succeeding years could bring their wagons by that road from The Dalles, over the Cascade Mountains, to Oregon City. By common consent of all good, honest pioneers, he had been named "The Good Doctor," and "The Good Old Doctor," and he was known by these names to the time of his death. They also came to call him the "Father of Oregon." Dr. McLoughlin's resignation from the Hudson's Bay Company became necessary to maintain his self-respect.

I have spoken of Capt. Park and Lieut. Peel, British officers, who brought the letters of Admiral Seymour and Captain Gordon to Dr. McLoughlin in 1845 . They were also sent as spies. They were succeeded by two more spies, Capt. Warre and Lieut. Vavasour, both of the British army. The two latter stayed at Fort Vancouver and elsewhere in Oregon for some time. In their report Warre and Vavasour charged, mainly, that the policy pursued by Dr. McLoughlin and the Hudson's Bay Company, at the different forts in the Oregon Country, had tended to the introduction of Ameri- 
can settlers into the country until they outnumbered the British. To prove this position, they instanced the assistance rendered the different immigrations, one of which (1845) was arriving while they were at Vancouver. They charged that goods had been sold to the American settlers at cheaper rates than to British subjects; that Dr. McLoughlin and the Company had suffered themselves to join the Provisional Government "without any reserve except the mere form of the oath;" that their lands had been invaded, and themselves insulted, until they required the protection of the British government "against the very people to the introduction of whom they had been more than accessory." There was more in this report of like import.

As was to be expected Dr. McLoughlin's answer was dignified, forceful, and sufficient. I give only a few of his points. ${ }^{26}$ In his answer Dr. McLoughlin said, concerning his treatment of the missionaries: "What would you have? Would you have me turn the cold shoulder to the men of God, who came to do that for the Indians which this Company has neglected to do?" He said he had tried to prevent the American settlers remaining idle, becoming destitute, and dangerous to the Company's servants. Drive them away he could not, having neither the right nor the power. That these settlers had not come expecting a cordial reception from him, but quite the contrary; that while he had done some things for humanity's sake, he had

\footnotetext{
${ }^{20}$ A full summary will be found in Vol. I, pp. 501-505, History of Oregon, Bancroft's Works.
} 
intended to, and had averted evil to the Company by using kindness and courtesy towards the American immigrants. As to joining the Provisional Government he showed the necessity and wisdom of his actions under the circumstances. To the accusation that the Company had submitted to insult, he said: "They were not to consider themselves insulted because an ignorant man thought he had a better right than they had." As to the British government, it had not afforded protection in time, and that it was not the duty of the Hudson's Bay Company to defend Great Britain's right to territory. 'The obligation of the Company's officers, whatever their feelings might be, was to do their duty to the Company. He admitted helping the immigrants of $1843, \mathrm{I} 844$, and 1845 , and saving the lives and property of the destitute and sick. He also admitted to assisting the immigrants of 1843 to raise a crop for their own support and of saving the Company from the necessity of feeding the next immigration. And he said: "If we had not done this, Vancouver would have been destroyed and the world would have judged us treated as our inhuman conduct deserved; every officer of the Company, from the Governor down, would have been covered with obloquy, the Company's business in this department would have been ruined, and the trouble which would have arisen in consequence would have probably involved the British and American nations in war. If I have been the means, by my measures, of arresting any of these evils, I shall be amply repaid by the approbation of my conscience. It is true that $I$ have 
heard some say they would have done differently; and, if my memory does not deceive me, I think I heard Mr. Vavasour say this; but as explanation might give publicity to my apprehension and object, and destroy my measures, I was silent, in the full reliance that some day justice would be done me." 27

The Governor and the directors of the Hudson's Bay Company apparently neither understood nor appreciated the conditions in Oregon in 1843 , and in the immediate succeeding years, or Dr. McLoughlin's motives and humanity in assisting the immigrants. While the Governor in Chief and these directors were probably men of high character, and, individually, men of humanity, as representatives of this great trading company, they seemed to have considered Dr. McLoughlin's actions in assisting the American immigrants to settle in parts of the disputed Oregon Country by relieving their distresses, and saving them from suffering and starvation, as amounting almost to treason to his Country and as being untrue and false to the Hudson's Bay Company and its interests. They believed that he had failed to carry out its policies, if not its express instructions, which they felt he should have followed, as the chief of its enterprises west of the Rocky Mountains, no matter what the circumstances were or what the consequences might be. They did not seem to understand that, if the early immigrants had not been assisted, helped, and rescued, as they were, by Dr. McLoughlin, it might have been fatal to

${ }^{27}$ See Document R. 
Fort Vancouver and precipitated a war between the United States and Great Britain. As has been already said the Hudson's Bay Company, under royal grant, had an absolute monopoly in trading with the Indians in what was called British America, that is, northward and westward of the United States, excepting the British Provinces and also excepting the Oregon Country. In the latter the Company had the exclusive right, under said grant, to trade with the Indians, but on the condition that it should not be to the prejudice nor exclusion of citizens of the United States, who had the right to be in the Oregon Country under the convention of joint-occupancy. ${ }^{28}$ Undoubtedly the Governor in Chief and directors of the Hudson's Bay Company had a feeling that the Company and its trade should not be interfered with in the Oregon Country. For more than thirty years it and the Northwest Company, with which it had coalesced in $182 \mathrm{I}$, had had almost absolute control of trade with the Indians in nearly all of the Oregon Country. Its practical monopoly there had been almost as complete as its actual monopoly in British America. The exercise of absolute power usually begets a feeling of a right to continue the exercise of such power. The head-officers of the Company resented the actions of Dr. McLoughlin which tended to weaken the power of the Hudson's Bay Company and to interfere with its control of the fur trade in the Oregon Country.

An Indian trading company is much more likely to be mercenary than humane. The headquar-

${ }^{28}$ See Document $C$. 
ters of the Hudson's Bay Company were at London. Oregon was a long distance from London. Under the conditions it may not be surprising that greed of gain and selfish interests outweighed humanity in the minds of these officers in charge of the Hudson's Bay Company. It is true none of them were in Oregon when these immigrants came. None of these officers had ever been in the Oregon Country, excepting Sir George Simpson, the Governor in Chief. These officers did not see the distresses, the sufferings, or the perils of these immigrants. Their information came largely from others, who were not friends of Dr. McLoughlin, and who did not approve his actions. Dr. McLoughlin had been for so long a time a Chief Factor of the Company; he had been, up to the arrival of the immigration of $\mathrm{I} 843$, so faithful to its policies and interests; he had so increased its trade, and added so largely to its revenues, that he could not be summarily dismissed. But he was a man of pride and of high quality, and he could be forced to resign. This the Governor in Chief and the directors of the Hudson's Bay Company accomplished. In thus acting unjustly to Dr. McLoughlin, they were unconsciously assisting to make him the eternal hero of Oregon. In resigning Dr. McLoughlin gave up a salary of twelve thousand dollars a year. He made his home at Oregon City, where he expected to pass the rest of his life, with the intention of becoming an American citizen as soon as possible. He invested his wealth at Oregon City in various enterprises in an attempt to assist in upbuilding Oregon. 
His resignation marks the beginning of his tribulations which ended only with his death. The details I shall presently set forth. In assisting the immigrants Dr. McLoughlin did not count the cost nor fear the consequences. His humanity was greater than his liking for wealth or position. He had no greed for gain, no selfishness. Had he anticipated the consequences I believe that he would not have hesitated nor acted otherwise than he did. Frances Fuller Victor wrote of Dr. McLoughlin and his tribulations: ${ }^{29}$ "Aristocrat, as he was considered by the colonists [American settlers] and autocrat as he really was, for twenty years throughout the country west of the Rocky Mountains, he still bravely returned the assaults of his enemies in the language of a republican. He defended the American character from the slurs of government spies, saying, 'they have the same right to come that I have to be here,' touching lightly upon the ingratitude of those who forgot to pay him their just debts, and the rudeness of those, whom White mentions as making him blush for American honor. But whether he favored the Company's interests against the British, or British interests against the Company's, or maintained both against the American interests, or favored the American interests against either, or labored to preserve harmony between all, the suspicions of both conflicting parties fell upon him, and being forced to maintain silence he had the bad fortune to be pulled to pieces between them."

${ }^{20}$ Vol. 1, pp. 504, 505, History of Oregon, Bancroft's Works. 
Dr. McLoughlin's Religion.

When an infant, Dr. McLoughlin was baptized in the Roman Catholic Church. His father and mother were of that church. While living with the family of his maternal grandfather, he probably was brought up in the English Established Church, of which he became a member. Prior to 184 I or 1842 , it was his custom, at Fort Vancouver, to read the service of that church on Sundays to the congregation of officers and employées who attended. Dr. McLoughlin was a broad man in every way. He recognized the good in all Christian sects and denominations. He assisted the Methodist, Presbyterian and Congregational missionaries. Had he been a member of those churches, he could hardly have done more for them than he did. While still a Protestant, he also assisted the Roman Catholic missionaries, from their first coming to Oregon, in 1838 , as he had the Protestant. He never tried to change the forms of religion of his employées and servants of the Company. He encouraged them in their devotion to the religions of their choice.

Archbishop Francis Norbert Blanchet in his "Historical Sketches of the Catholic Church in Oregon," says (page 68): "It is but just to make special mention of the important services which Dr. John McLoughlin - though not a Catholic has rendered to the French Canadians and their families, during the fourteen years he was governor of Fort Vancouver. $\mathrm{He}$ it was who read to them the prayers on Sunday. Besides the English school kept for the children of the Bourgeois, he 
had a separate one maintained at his own expense, in which prayers and the catechism were taught in French to the Catholic women and children on Sundays and week days, by his orders. He also encouraged the chant of the canticles, in which he was assisted by his wife and daughter, who took much pleasure in this exercise. He visited and examined his school once a week. . . . He it was who saved the Catholics of the Fort and their children from the dangers of perversion, and who, finding the log church the Canadians had built, a few miles below Fairfield, in 1836 , not properly located, ordered it to be removed, and rebuilt on a large prairie, its present beautiful site."

Dr. McLoughlin was given charge of a girl by her dying father, who was a Protestant. Dr. McLoughlin would not send her to a Roman Catholic school. He respected the religious faith of the girl's father. ${ }^{30}$ There is some question as to whether Dr. McLoughlin became a Roman Catholic in the year 1841 or 1842 . In one of those years, Dr. McLoughlin read "The End of Controversy," written by Dr. Milner, and was converted by this book to the Roman Catholic faith and joined that church. He made his abjuration and profession of faith and took his first communion at Fort Vancouver in 1841 or 1842 . Joining the Roman Catholic Church by Dr. McLoughlin was most impolitic, at this time, particularly on account of his land claim. But he was not a man to consider policy when there was something to be

\footnotetext{
${ }^{80}$ Vol. r, p. 31, History of Oregon, Bancroft's Works, from manuscript of Jesse Applegate.
} 
done, which he thought right, just, or proper. Otherwise, he would not have assisted the missionaries nor helped the immigrants. Joining the Roman Catholic Church only added to the opposition to Dr. McLoughlin. He was then a British subject. At that time there was great prejudice by many Americans against Great Britain as the supposed hereditary enemy of the United States. The long discussion of the Oregon Question; the election of Polk as President in 1844 , largely on the popular cry of " $54-40$ or fight," greatly intensified this feeling. There was also great popular prejudice among many of the Protestants of the United States against the Roman Catholic Church, which had been handed down from the time of the settlement of New England and the Cromwellian revolution in England. Locally, in Oregon, a partial success of the Roman Catholic missionaries with the Indians, where the Protestants had failed, probably intensified this feeling.

In these early immigrations were many women, most of whom were wives and mothers. There were also numerous children of all ages. There were a few births on the way. When these mothers saw their children, along the Columbia River, in peril, many sick and almost famishing; when they heard their children cry for food and clothing, which these mothers could not supply; and when these perils were removed, and these necessaries were furnished by Dr. McLoughlin, and their sick children were restored to health under his orders and directions; do you think these Protestant American mothers considered it important 
that Dr. John McLoughlin was a Roman Catholic and a British subject? Or that they were not grateful?

\section{Dr. McLoughlin's Land Claim.}

I shall now take up the matter of Dr. McLoughlin's land claim at Oregon City. Many writers and speakers have spoken of his land claim being taken from him, in a loose way, as "unjust treatment," or as "robbery." I shall briefly state the facts, as I have found them. The early pioneers know these facts. They should be known by everyone in justice to Dr. McLoughlin and to his memory.

Prior to the Donation Land Law, there were no lawful titles to lands in Oregon, except lands given to Missions by the law establishing the Territory of Oregon. The Donation Land Law was passed by Congress, and was approved by the President September 27,1850 . Prior to the organization, in I843, of the Oregon Provisional Government, the only law, or rule of law, in Oregon was the Golden Rule, or rather a consensus of public opinion among the few settlers in Oregon. When a person settled on a piece of land and improved it, or declared his intention to claim it, all other settlers respected his possessory rights. Each settler thought that on the settlement of the boundary line between the United States and Great Britain, his land claim would be recognized and protected, which he had thus claimed while there was jointoccupancy under the Conventions of 1818 and 1827. 
It was in 1829 that Etienne Lucier, one of the Hudson's Bay Company's servants, of whom I have spoken, settled in the Willamette Valley at French Prairie, now in Marion County. Other servants of the Hudson's Bay Company, as their terms of service expired, and a few Americans, had settled at or near French Prairie prior to 1834 , so that when the first missionaries came, there was a thriving, although small, settlement near where Jason and Daniel Lee established their first mission in I834. This mission had no title to the land where the Mission was established, yet its rights were recognized and respected.

In 1829 Dr. McLoughlin for himself took possession of the land and water power at the falls of the Willamette River on the east side of the river at and near what is now Oregon City. In his land claim was the valuable, but small, island containing about four or five acres of available area in low water, and two or three acres in ordinary high water. It was separated from the east bank by a part of the river, in summer not more than forty feet wide; it was situated near the crest of the falls. Its location made it valuable for convenient use of water power. This island was afterwards known as "Governor's Island," but was called "Abernethy Island" in the Donation Land Law, and is now known by the latter name. This island is now owned by the Portland General Electric Company. It lies partly in the "Basin" at Oregon City. On it is now erected a large wooden building called, by that Company, "Station A." As I have said, in 1825 the Hudson's Bay Company knew that 
England did not intend to claim any part of the Oregon Country south of the Columbia River, so it did not want for itself any permanent or valuable improvements in the Willamette Valley.

In I829 Dr. McLoughlin began the erection of a sawmill at the falls. He caused three houses to be erected and some timbers to be squared for a mill. This work continued until May, 1830 . In 1829 the Indians there burned these squared timbers. In 1832 he had a mill-race blasted out of the rocks from the head of the island. It has been asserted that these improvements were made for the Hudson's Bay Company, but were discontinued by it because it did not wish to erect valuable improvements there. But in the McLoughlin Document he says: "I had selected for a claim, Oregon City, in 1829, made improvements on it, and had a large quantity of timber squared." Who ever knew or heard of Dr. McLoughlin telling a lie? That he was a man of the highest honor and truthfulness is established beyond all doubt. This claim was taken by him in the same year that Lucier settled in the Willamette Valley. It is evident that Dr. McLoughlin took this claim, for his old age and for the benefit of himself and children. ${ }^{31}$ From about 1838 until the passage of the Donation Land Law in 1850 , he openly and continuously asserted his right to his land claim, including Abernethy Island. No adverse claim was made until about July, I840, less than sixty days after the arrival of the ship Lausanne, when certain members of the Methodist Mission began to plan to take these

\footnotetext{
${ }^{31}$ See Document L.
} 
lands and rights from Dr. McLoughlin, and in the end succeeded, but only partially for themselves. Dr. McLoughlin's right to his land claim was as good as that of any other person in Oregon to his own land claim. April I, I843, Dr. Elijah White, who came to Oregon in 1837 , as a Methodist missionary, but was then United States Sub-Agent of Indian Affairs, in an official report to the Commissioner of Indian Affairs, at Washington, D. C., said of the Shortess petition, to which I shall presently refer: "A petition started from this country today, making bitter complaints against the Hudson's Bay Company and Governor McLoughlin. On reference to it (a copy was denied) I shall only say, had any gentleman disconnected with the Hudson's Bay Company been at half the pains and expense to establish a claim on the Wallamet Falls, very few would have raised any opposition." ${ }^{32}$ Under the joint-occupancy every British subject had the same or equal rights in the Oregon Country that a citizen of the United States had.

December I8, 1839, Senator Linn introduced a series of resolutions in the United States Senate, which were referred to a select Committee. March 3I, I840, this Committee reported a substitute. The chief feature was a provision for granting to each male inhabitant of Oregon, over eighteen years of age, one thousand acres of land. December I6, I841, Senator Linn introduced his famous bill thereafter known as the "Linn Bill," which granted six hundred and forty acres of land to every white male inhabitant of Oregon, of eigh-

\footnotetext{
${ }^{32}$ White's Ten Years in Oregon, p. 200.
} 
teen years or over, who should cultivate the same for five years. This bill was favorably reported back to the Senate and subsequently passed the Senate, but failed in the House. The Oregon Donation Land Law was largely based on this bill. In neither the Linn resolution nor in the Linn bill was any difference made between American citizens and British subjects, or other aliens as to the right to take land. The Oregon Donation Land Law of September 27, 1850, applied to every white settler (including aliens) over eighteen years of age then a resident of Oregon, or who should become such a resident prior to December I, 1850 , except Dr. McLoughlin. In case of an alien he must either have made his declaration, according to law, to become a citizen of the United States prior to the passage of the Donation Land Law or do so prior to December I, I85 I. The Linn bill was largely instrumental in causing the early immigrations to Oregon. It was felt by these immigrants that it, or a similar law, was bound to pass Congress. The Oregon Donation Land Law was such a law. Dr. McLoughlin believed that such a bill was bound to become a law.

The Methodist Mission, as a mission, did not, officially, attempt to deprive Dr. McLoughlin of any of his land. There were some of the missionaries who opposed any such action. But others of them saw that if the Mission obtained any of Dr. McLoughlin's land claim, it would belong to the Mission or to the Church, so they readily proceeded, as individuals, for their own private gain. In 1840 , shortly after the arrival of the Lausanne, 
Rev. Jason Lee, as Superintendent of the Methodist Mission, appointed Rev. A. F. Waller to labor for the Indians at Willamette Falls and vicinity. The Mission took up a claim of six hundred and forty acres north of Dr. McLoughlin's claim. The Mission's religious work was done by Waller on this claim, where Gladstone Park is now situated, and also at a point on the west bank of the Willamette River opposite Oregon City. At both of these places there were a number of Indians. ${ }^{33}$ In the summer of 1840 Waller was sent to establish this Mission. Dr. McLoughlin generously assisted the undertaking. He gave the Mission a piece of land in his claim on which to erect a missionhouse; and, at the request of Rev. Jason Lee, the Superintendent of the Mission, Dr. McLoughlin loaned it some of the timbers, which he had caused to be squared, to build the mission-house. Timbers to take the place of those so loaned were never furnished to Dr. McLoughlin, nor were the timbers ever paid for. ${ }^{34}$ It was soon reported to Dr. McLoughlin that the Methodist Mission would try to take or to jump his claim. He at once (July 2I, I840) notified Jason Lee, Superintendent of the Mission, of the facts: That Dr. McLoughlin had taken possession of this land claim in 1829 , and also of his intention to hold this land as a private claim. He gave Lee the general description of the land so claimed by Dr. McLoughlin, viz: "From the upper end of the falls across to the Clackamas river, and down where the Clackamas

\footnotetext{
${ }^{3 s}$ Rev. Dr. H. K. Hines, Missionary History, p. 354.

st See Document L.
} 
falls into the Willamette, including the whole point of land, and the small island in the falls on which the portage was made." This is the island later known as "Governor's" or "Abernethy" Island. After giving the notice mentioned, Dr. McLoughlin concluded his letter with these words: "This is not to prevent your building the store, as my object is merely to establish my claim." A satisfactory answer was returned and Waller proceeded in the erection of the mission-house, which was divided into two apartments, one of which served as a dwelling, and the other as a storeroom for the goods of the Mission. ${ }^{35}$

In 1841 Felix Hathaway, in the employment of the Mission, began to build a house on the island, at which Dr. McLoughlin remonstrated with Waller, but the latter assured Dr. McLoughlin that no wrong was intended and Hathaway stopped his building operations. Matters ran smoothly until the autumn of 1842 . By this time Dr. McLoughlin had again made improvements on his claim, having it surveyed and part of it laid off in town lots and blocks, which he named Oregon City. Some of these lots and blocks he gave away, some he sold. I cannot go into all the evasive actions of Waller and the false statements and claims made by him, and by John Ricord, his attorney, in relation to Waller's supposed rights to Dr. McLoughlin's land claim. Waller employed Ricord as an attorney and asserted his ownership of all the McLoughlin land claim, except Abernethy Island,

${ }^{35}$ Vol. I, p. 204, History of Oregon, Bancroft's Works. See also Document L. 
to which the Oregon Milling Company laid claim. A public proclamation signed by Ricord as attorney for Waller, although dated December 20, I843, was publicly posted at Oregon City early in 1844. It set forth the alleged illegality of Dr. McLoughlin's claim and the imaginary rights of Waller. ${ }^{36}$ Whatever possession Waller had of any part of this land was due to the kind permission of Dr. McLoughlin. Waller attempted to turn this kindness into a question of right to the whole land claim, excepting Abernethy Island. An agreement or settlement, dated April 4, I844, was executed by Rev. A. F. Waller, Rev. David Leslie, acting Superintendent of the Methodist Mission, and by Dr. McLoughlin. Under this agreement Dr. McLoughlin was compelled to pay Waller five hundred dollars and to convey to Waller eight lots and three blocks in Oregon City, and also to convey to the Methodist Mission six lots and one block in Oregon City. What right the Mission had to insist on the conveyance to it of this land has never been explained - Waller, in said agreement or settlement, surrendering and forever abandoning to Dr. McLoughlin "all claims, rights, and pretensions whatsoever" which Waller had to the land claim of Dr. McLoughlin, which is described in said agreement as "a tract of land situated at the falls of the Wallamette River on the east side of said River, containing six hundred and forty. acres, and surveyed by Jesse Applegate in the month of December, A. D. I843." This survey included Abernethy Island. There were not then

\footnotetext{
${ }^{30}$ This proclamation is set forth in full in Document $I$.
} 
any courts in Oregon to which Dr. McLoughlin could apply for relief, as he had not then joined the Provisional Government. It was probably better and cheaper for him to submit to this unfair agreement, otherwise he would have been compelled to allow Waller to take the land or to have ousted him by force. ${ }^{37}$

July I 5,1844 , about three months after this settlement, Rev. George Gary, who was then closing the Methodist Mission in Oregon and disposing of its property, in a letter to Dr. McLoughlin offered to sell back these lots and block given to the Mission by Dr. McLoughlin, with the improvements thereon, excluding the two lots given by Dr. McLoughlin in 1840 on which the Methodist Church was built. Gary valued the lots to be sold at two thousand, two hundred dollars, and the improvements thereon at three thousand, eight hundred dollars. Gary made the conditions that the possession of a warehouse should be reserved until June, I845, and the house occupied by George Abernethy until August, I845. Gary made some other reservations and wrote that there must be an answer in a day or two. Dr. McLoughlin considered this offer extortionate. He wrote an answer to Gary calling attention to the fact that he had so recently given the lots to the Mission, that it would be the fairest way for Gary to give Dr. McLoughlin back the lots, since the Mission had no longer any use for them, and let him pay for the improvements; that one of the houses was built with lumber borrowed from him and had

${ }^{87}$ This agreement is set forth in full in Document $J$. 
not been paid for. He suggested that the matter be referred to the Missionary Board. But Gary rejected every proposal. Dr. McLoughlin was compelled to yield and agreed to pay the six thousand dollars demanded by Gary. ${ }^{3 s}$ Notwithstanding the fact that this agreement executed by Waller and Leslie, dated April 4, I844, was made as a final settlement of the matter, the conspirators determined to deprive Dr. McLoughlin of his land claim, even if they did not profit by it. They succeeded by means of the Oregon Donation Law, as I shall presently show. These conspirators had previously arranged to take or "jump" Abernethy Island.

Rev. Dr. H. K. Hines was too honorable a man to justify these proceedings. As he came to Oregon in 1853 , it appears that he did not know all the facts, but such as he knew, even from Methodist missionary sources, did not commend Waller's actions to Hines in regard to Dr. McLoughlin and his land claim. In his Missionary History, pages 353-355, Dr. Hines says: "At Oregon City the Mission as such deemed it wisest not to file any claim as against that of Dr. McLoughlin, Chief Factor of the Hudson's Bay Company at Vancouver, who had made some movements toward the occupation of that valuable property before the Mission was established. Perhaps all in the country at that time, Mr. Lee included, did not consider the claim of Dr. McLoughlin as a British

${ }^{38}$ Vol. 1, p. 253, History of the Pacific Northwest, by Elwood Evans; The River of the West, by Frances Fuller Victor, pp. 360, 361; Vol. r, pp. 224, 225, History of Oregon, Bancroft's Works. 
subject and the head of a great British corporation, such a claim as would be recognized in law when the government of the United States should extend its jurisdiction over the country, which they believed it was sure to do in a short time.

The mission work at this general point was mostly done on the west side of the river at The Falls, and at the villages on the Clackamas where 'Gladstone Park' is now situated, and where the Mission had a farm, and a claim of a square mile of land. This stood in exactly the same relation to the Board as did the claim at The Dalles and at Salem.

"It is proper that we say here that much controversy arose at Oregon City through the fact that Rev. A. F. Waller filed a claim in his own behalf on the land to which Dr. McLoughlin was also laying claim, on the ground that the latter, being a British subject, could not obtain title under the land laws of the United States. With this the Mission, as such, had no connection whatever, and hence this history does not deal with the question." Nevertheless, joint-occupancy, Senator Linn's resolution and bill, the Donation Land Law, subsequently passed, natural justice and right, and common decency should have been recognized as giving Dr. McLoughlin full right to his land claim from the beginning.

At least three of the Methodist missionaries and those connected with the Methodist Mission were not citizens of the United States at any time prior to the passage of the Donation Land Law in 1850 . Rev. Jason Lee was a native of Canada and died in Canada. He did not become a citizen of the 
United States. His allegiance was always that of a British subject. Jason Lee was of English descent. His parents were born in the United States but settled at Stanstead, Canada, and made it their home several years prior to his birth. He was born at Stanstead in 1803 and that was his home until I834, when he came to Oregon. For a number of years he worked in the pineries in the north of Canada. In 1826 he was "converted" and joined the Wesleyan Church of Canada. In 1827 he entered the Wesleyan Academy at Wilbraham, Massachusetts. After attending that Academy for a time, he returned to his home at Stanstead, where he stayed for several years, first teaching school and afterwards becoming a preacher of the Wesleyan Church of Canada. For several years he had desired to be a missionary among the Indians and in 1832 or 1833 offered his services as a missionary to the Indians of Canada to the Wesleyan Missionary Society of London. In I833, while waiting a reply to his application, he was offered the appointment by the New England Conference of the Methodist Episcopal Church of "Missionary to the Flathead Indians," and was admitted as a member of the latter Conference. In the spring of 1834 he started for Oregon, which, during the rest of his life, was jointly occupied by citizens of the United States and subjects of Great Britain under the Conventions between these countries. The political status of a resident of Oregon then remained as it was when he arrived in Oregon. It could not be changed there during joint-occupancy. He died at Lake Memphrema- 
gog in Canada, March 2, 1845 . His body was buried at Stanstead. These facts I have obtained mostly from Dr. Hines' Missionary History of the Pacific Northwest, and I have verified them from other reliable sources.

Rev. Daniel Lee was also born in Canada. Up to the time of his return to the Eastern States in I 843 , he had not become a citizen of the United States. As the rest of his life was spent as a Methodist minister in the United States, he probably became a citizen of the latter country. Rev. Daniel Lee, I believe, took no part in, nor did he encourage, or sympathize with any action against $\mathrm{Dr}$. McLoughlin.

Joseph Holman (not a relative of mine) was born in England, August 20, I8I5. In 1833 he went to Canada where he lived for several years. About 1836 or 1837 he went to Ohio and later went to Illinois. In 1839 he started for Oregon. $\mathrm{He}$ arrived at Fort Vancouver June I, I840, the same day the Lausanne arrived there. In 1840 or $184 \mathrm{I}$ he became connected with the Methodist Mission. Shortly after his arrival he took up a land claim a mile square near the present city of Salem. A person could not become a citizen of the United States until he had resided therein for at least five years. So he could not become such a citizen in the East for he had not resided in the United States more than three years when he started for Oregon in I 839. It was in Oregon, after the United States Courts were established in 1849 , that Joseph Holman first made application to become a citizen of the United States and became one. As Jason Lee 
and Daniel Lee took up the land on which the Methodist Mission was situated and they were British subjects, their rights as land claimants were the same as those of Dr. McLoughlin. The Mission, as such, had no legal status to acquire land prior to the Act of 1848 organizing Oregon Territory. The land claim of Joseph Holman had the same status as that of Dr. McLoughlin - just as good, but no better.

\section{Abernethy Island.}

I have spoken of this settlement with Waller, in 1844 , in order to treat separately of the taking of Abernethy Island from Dr. McLoughlin. The land controlling the water-power on the west side of the falls of the Willamette River was not taken nor claimed by any one until after the year I84I. It is on the west side where the water-power of the falls is now mostly used. It could have been had for the taking at the time Abernethy Island was "jumped." Dr. McLoughlin's land claim was on the east side of the river. As I have said, Felix Hathaway, in the employment of the Mission, in I 84 I began to build a house on Abernethy Island, but after Dr. McLoughlin's remonstrance to Waller, the building operations on the island ceased at that time. Dr. McLoughlin erected a small house on the island. In I 84 I the Oregon Milling Company was formed. Almost all of its members belonged to the Methodist Mission. Hathaway conveyed all his right and title to the island to the Oregon Milling Company, a part of the consideration to be paid by a Committee of the Oregon 
Milling Company in behalf of that Company. Rev. A. F. Waller is the one first named, of the Committee, in the deed. This deed is recorded at page 52 of Book 2, Record of Deeds of Clackamas County. This record shows the date of the deed as November 23, I 852 . This is evidently an error of the copyist, as to the year. It doubtless was I 842 , for Hathaway, by the deed, conveyed all his "right and title to the island on which said Company are now constructing mills," etc. This is a very religious deed. Hathaway in this conveyance covenanted to warrant and defend the island against all persons "(the Lord excepted)."

Among the cargo of the Lausanne, which all belonged to the Methodist Mission, was machinery for flour-mills and for saw-mills. The Methodist Mission established both a saw-miil and a grist-mill, run by water-power, near Chemekete (now Salem). These were in operation in $184 \mathrm{I}$. These mills were much nearer the Willamette settlements than Oregon City was. In the Fall of 1842 the Oregon Milling Company had erected a saw-mill on the island, intending to follow it with the erection of a flour-mill. It will be noted that there were then no courts in Oregon, for the Provisional Government was not organized until 1843. Dr. McLoughlin and the Hudson's Bay Company were not under the jurisdiction of the Provisional Government until 1845 . In the fall of I 842 Dr. McLoughlin became satisfied that it was the intention of some of the Methodist missionaries to take his land and to deprive him of his water rights. To save his interests he forthwith built a 
saw-mill on the river bank near the island, and gave notice that he would erect a flour-mill in a short time.

\section{The Shortess Petition.}

The enemies of Dr. McLoughlin then determined to send a petition to Congress. It is said that this petition was drawn by George Abernethy, who then, as steward of the Mission, kept its store at Oregon City, and had charge of all its secular affairs, but that Abernethy was unwilling to have it known that he was connected with the petition, so it was copied by a clerk, named Albert E. Wilson. Abernethy wished to appear friendly to Dr. McLoughlin; to act otherwise might hurt the Mission and Abernethy in his business. ${ }^{39}$ The first signature to this petition was that of Robert Shortess, who arrived in the Willamette Valley in April, I 840 . He joined the Methodist Church about I841. He was then intense in his dislike of the Hudson's Bay Company and its officers. From the fact that he was the first signer, this petition is known as the "Shortess petition." It was signed by sixty-five persons. Of these about one-third were immigrants of 1842 , who had been in the country less than six months. This petition is addressed to Congress. It is dated March 25, 1843 . It begins with a short statement that the petitioners have no laws to govern them. That "where the highest court of appeal is the rifle, safety in life and property cannot be depended on." Until these

${ }^{39}$ Vol. I, p. 207 , History of Oregon, Bancroft's Works; Vol. I, p. 243, Elwood Evans's History of the Pacific Northwest. See also Document $\mathrm{H}$. 
people attempted unfairly to take Dr. McLoughlin's land, the Golden Rule had prevailed and the appeal to the rifle was always "conspicuous by its absence." This petition then calls attention to the domination of the Hudson's Bay Company, and its successful opposition to Bonneville and Wyeth, and that that Company formerly would not sell cattle, and its opposition to the loan of cows and the return of the increase, which is true; and that in case of the death of a cow, the settler had to pay - which is false.

This petition further sets forth that in 1842 the settlers formed a company for supplying lumber and flour. That they selected an island at the falls of the Willamette. That after commencing they were informed by Dr. McLoughlin that the land was his. This is true, as to the company and the information by Dr. McLoughlin, but false, by indirection, in this, that they knew the island for years had been claimed by him as his property. The petition proceeds, "However, he erected a shed on the island, after the stuff was on the island to build a house, and then gave them permission to build under certain restrictions. They took the paper he wrote them containing his conditions, but did not obligate themselves to comply with the conditions, as they did not think his claim just or reasonable." In the latter statement the members of the Oregon Milling Company, who signed the petition, stated an estoppel to themselves. They could not enter into possession under conditions and then refuse to abide by them. This was pleading themselves out of Court, not to mention their admitted breach of faith. 
This petition then mentions the erection of the saw-mill by the Oregon Milling Company and complains of the erection of a mill by Dr. McLoughlin, and says that he can manufacture lumber cheaper than the Milling Company can. Nevertheless, the Oregon Milling Company succeeded. This petition then goes into puerility about the measurement of wheat by the Hudson's Bay Company, which Dr. White in his report, dated April I, I843, to the Commissioner of Indian Affairs, and hereinbefore referred to, says is untrue, for he knows the measure to be exact. This petition does not state (which is true) that when Dr. McLoughlin found that wheat weighed more than sixty pounds to the bushel, he raised the price paid to settlers, correspondingly. This petition sets forth, however, that Dr. McLoughlin had surveyed his claim, platted it, and called it Oregon City; and that he had given a notice dated January I 8,1843 , requiring all persons claiming lots on his land, before February I, I843, to apply for a deed, or a bond for a deed, as the case might be, which he would give. Dr. McLoughlin required a payment of five dollars to his attorney for making the deed or bond. As these people were all trespassers, it would seem that this action of $\mathrm{Dr}$. McLoughlin was a very generous one.

There is a very significant phrase in the Shortess petition, which indicates that the conspiracy to deprive Dr. McLoughlin of his land claim had its inception before that time. In this petition, after saying that Dr. McLoughlin did not own his Oregon City land claim, it is said "and which we hope 
he never will own." This phrase is omitted in the copy of the Shortess petition in Gray's History of Oregon and in Brown's Political History of Oregon. ${ }^{40}$ This phrase is referred to in Thurston's speech of December 26 , I850, as justifying his actions in giving Dr. McLoughlin's land claim to Oregon for an university. ${ }^{41}$ I shall not discuss some of the allegations of this petition, as they are trivial and unimportant. This petition was given to W. C. Sutton to be taken to Washington. Dr. McLoughlin applied to Shortess for a copy of this petition, but the request was refused.

Land Laws of the Provisional Government.

As I have stated, in July, 1843 , the Provisional Government went into effect. Its land laws were purposely framed against Dr. McLoughlin's claim, and in favor of the Methodist Mission. These land laws allowed any person, without regard to citizenship, who was then holding or wished to establish a land claim in Oregon, not exceeding 640 acres, "in a square or oblong form, according to the natural situation of the premises," to have such land claim. Those in possession were allowed one year in which to file a description of the claim in the Recorder's office. Dr. McLoughlin filed his description in 1843 . The survey was made by Jesse Applegate in 1843 . The record is now in the office of the Secretary of State at Salem, Oregon. In having this survey made Dr. Mc-

\footnotetext{
${ }^{40}$ See Document $\mathrm{H}$, which is a true copy of all the Shortess petition as printed in 1844 by order of the United States Senate.

"See Document N.
} 
Loughlin had it extend only about half way from the falls to the Clackamas River and so as to include not more than six hundred and forty acres. $\mathrm{He}$ abandoned that part of his original claim extending between his new north line and the Clackamas River.

Article 4 of these land laws of 1843 was the one intended to deprive Dr. McLoughlin of his claim. It was as follows: "Art. 4. No person shall be entitled to hold such a claim upon city or town sites, extensive water privileges, or other situations necessary for the transaction of mercantile or manufacturing operations, to the detriment of the community: Provided, that nothing in these laws shall be so construed as to effect any claim of any mission of a religious character, made previous to this time, of an extent of not more than six miles square." This land law was amended in July, 1845. The only material change, so far as is necessary for the purposes of this monograph, was that said Section 4 of the land laws of 1843 was repealed. It was after the repeal of the objectionable and unfair Section 4 of the land laws of 1843 that Dr. McLoughlin for himself and the Hudson's Bay Company joined the Provisional Government.

Dr. McLoughlin's Naturalization.

After Dr. McLoughlin sent his resignation to the Hudson's Bay Company, in 1845 , he determined to become a citizen of the United States. In 1845 he consulted with Peter H. Burnett, then Chief-Justice of the Provisional Government, and with Jesse Applegate, about taking the oath of al- 
legiance to the United States, and taking out his first naturalization papers, but Burnett had no authority from the United States, or other jurisdiction, to administer such an oath (or to issue such papers) and so advised Dr. McLoughlin. Although this matter was well known in Oregon, it gave Dr. McLoughlin's enemies a chance to say that he was a British subject, and had not taken the oath of allegiance to the United States, nor applied to become a citizen of the United States. August 14, I 848, the bill establishing the Territory of Oregon became a law. March 2, 1849, General Joseph Lane, the first Territorial Governor of Oregon, arrived at Oregon City. March 3, I849, he issued his proclamation assuming charge as governor. Soon after the Territory of Oregon was organized and courts of the United States established. The assignment of Judges to their respective districts was made May 13, I849. May 30, 1849 , Dr. McLoughlin took the oath and made his declaration to become a citizen of the United States, as required by the naturalization law. So he acted with promptness. This was well known in Oregon at the time. Dr. McLoughlin voted at Oregon City at the first general election held in June, 1849 , but he did not vote for Thurston as delegate to Congress, which Thurston knew. Under the act of Congress, organizing Oregon as a territory, all aliens who had declared, on oath, their intentions to become citizens of the United States, and taken an oath to support the Constitution of the United States and the provisions of the act establishing the Territorial Government of Oregon, were entitled to vote at the first election. 
Dr. McLoughlin became a citizen of the United States, at Oregon City, September 5, I851. The naturalization law then allowed an alien to become a citizen of the United States two years after taking the oath and making his declaration, if he had lived in the United States for five years. His witnesses were A. L. Lovejoy, A. A. Skinner, and Theodore Magruder. His admission to citizenship was based on his said oath and declaration of May 30, I 849 .

Conspiracy against Dr. McLoughlin.

It was in 1849 that the conspiracy against Dr. McLoughlin and his land claim began to become effective. In 1846 Governor Abernethy became the sole owner of the Oregon Milling Company and its property on Abernethy Island, Abernethy and his son claiming to own the island, which was then known as "Governor's Island," in supposed compliment to Governor Abernethy. W. P. Bryant, the first Territorial Chief-Justice of Oregon, arrived in Oregon April 9, I849. May 29, 1849, fifty days after his arrival he purchased all said interests of Gov. Abernethy and son. Bryant gave his promissory notes to Gov. Abernethy, aggregating $\$ 30,000$ in principal, as part consideration for the purchase. Bryant also bought from Gov. Abernethy, on time, wheat, flour, and staves for about $\$ 2500$ and a quantity of lumber and logs, the value of which I am unable to give. Bryant's judicial district included Oregon City. ${ }^{42}$

In June, I 849 , Samuel R. Thurston was elected

${ }^{42}$ See Document $\mathrm{K}$. 
Territorial Delegate to Congress from Oregon. $\mathrm{He}$ arrived in Oregon in the fall of 1847 . He was shrewd enough to obtain the support of the Mission Party. He skillfully made his canvass largely against the Hudson's Bay Company. Having the support of the Mission Party, and many of the voters being then in the California mines, Thurston was elected. The vote was as follows: Thurston, 470; Columbus Lancaster, 321 ; J. W. Nesmith, Io6; Joseph L. Meek, 40; and J. S. Griffin, 8. The most important measure for Oregon was the passage of a land law, for no person had or could then obtain a legal title to land. It was all owned by the United States except the small portions granted to the Missions. Thurston used his best endeavors to obtain the passage of such a bill. But he was anxious for re-election and to ingratiate himself with the Mission Party and the conspirators against Dr. McLoughlin.

\section{Thurston's Letter to Congress.}

Thurston prepared the way, by a letter addressed to the members of the House of Representatives, for introducing into the land bill a section depriving Dr. McLoughlin of his Oregon City claim. This letter contains many false statements. This section is section eleven of the Donation Land Law, which was passed without opposition. To this section I shall presently refer.

This letter to the members of the House of Representatives was issued by Thurston at Washington, D. C., in the month of May or the early part of June, I850. Said letter was published in full 
in the Oregon Spectator of September I2, I850. Nothing was known in Oregon or California of this letter until late in August or early in September, I 850 . As this letter is quite long and relates mostly to the general features of the Oregon Donation Land Bill and the necessity of its passage, I have omitted all that part of the letter excepting Thurston's discussion of the eleventh section of that bill, which contains all that part of the letter referring to Dr. McLoughlin and his land claim. In that part of his letter Thurston said:

"I will next call your attention to the eleventh section of the bill, reserving the town site of Oregon City, known as the 'Oregon City Claim.' The capital of our Territory is located here (Oregon City) and here is the county seat of Clackamas County. It is unquestionably the finest water power in the known world; and as it is now, so will remain, the great inland business point for the Territory. This claim has been wrongfully wrested by Dr. McLoughlin from American citizens. The Methodist Mission first took the claim, with the view of establishing here their mills and Mission. They were forced to leave it under the fear of having the savages of Oregon let loose upon them; and, successively, a number of citizens of our Country have been driven from it, while Dr. McLoughlin was yet at the head of the Hudson's Bay Company, west of the Rocky Mountains. Having at his command the Indians of the country, he has held it by violence and dint of threats up to this time. He had sold lots up to the $4^{\text {th }}$ of March, I849, worth $\$ 200$, O0O. $\mathrm{He}$ also has upon it a flouring mill, 
graineries, two double sawmills, a large number of houses, stores, and other buildings, to which he may be entitled by virtue of his possessory rights, under the treaty of 1846 . For only a part of these improvements which he may thus hold, he has been urged during the past year to take $\$ 250,000$. He will already have made a half million out of that claim. He is still an Englishman, still connected in interest with the Hudson's Bay Company, and still refuses to file his intentions to become an American citizen, and assigns as a reason to the Supreme Judge of the Territory, that he cannot do it without prejudicing his standing in England. Last summer, he informed the writer of this, that whatever was made out of this claim was to go into the common fund of the Hudson's Bay Company, of which he and other stockholders would share in proportion to their stock; in other words, that he was holding the claim for the benefit of the Company. Now, the bill proposes to reserve this claim; subject to whatever right he may have to it, or any part of it, by virtue of the treaty; and confirms the title of all lots sold or donated by him previous to March $4^{\text {th }}, 1849$. This is designed to prevent litigation. That day is fixed on, because, on that day, in Oregon City, Governor Lane took possession of the Territory, declaring the laws of the United States in force, and apprising Dr. McLoughlin and all others, that no one had a right to sell or meddle with the Government lands. Dr. McLoughlin ought to have been made to pay back the $\$ 200,000$, but not wishing to create any litigation, the committee concluded to quiet the whole 
matter by confirming the lots. Having in this way made $\$ 200,000$, and his possessory rights, if it shall turn out that he lawfully acquired any, being worth $\$ 200,000$ more, the people of Oregon think our bounty is sufficient to this man, who has worked diligently to break down the settlements ever since they commenced; and they ask you to save their capital, their county seat, and the balance of that noble water power from the grasp of this British propagandist, and bestow it on the young American generation in Oregon, in the shape of education, upon which you and the whole Country are to rely and to defend and protect the western outposts of this glorious Union. The children of my Country are looking up to you with countenances flashing eloquence, clamoring to be educated, and asking you, in simple but feeling language, where your charity begins. They call you 'fathers,' and ask you whether you will put the moral weapons of defence in your children's hands in the shape of education, or whether you will deny it to them, and put means into the hands of him who will turn and rend both you and them. They do not doubt your decision, nor do I.

"When the Methodist Missionaries were driven from this claim, they went on the island in the middle of the river, and constructed mills and made other improvements. This island is known as the Abernethy Island, and is of no value, except for the improvements upon it. It consists of about two acres of barren rock. This island was subsequently sold to George Abernethy, and the bill ought to confirm the same to Abernethy or his as- 
signs. - This is a simple act of justice to American citizens, who now have their mills and property staked on those rocks, and which, for a long time, stood the only mills in the valley, where an American could get any grain ground for toll. They are now, with the exception of Dr. McLoughlin's mills, nearly the only mills in the whole country left standing by the late freshet, and they have been very materially injured. They must be repaired at vast expense, and if they are not, Dr. McLoughlin will hold, as he has heretofore held, the bread of the people of the Territory in his own fist. Your brethren ask you to confirm their title to those rocks, that their property may stand there in safety. They doubt not your decision. Hence there should be an amendment in the bill to this effect."

It is not true, as asserted by Thurston, that the Methodist Mission first took the "Oregon City claim." It was first taken by Dr. McLoughlin, as I have shown. If the Methodist Mission ever took, or had any interest in this land claim, it was through a secret agreement or understanding with Waller, or with the Oregon Milling Company, excepting only the lots given to the Mission by Dr. McLoughlin in 1840 and those secured by the Mission under the Articles of Agreement, dated April 4, I $844{ }^{43}$ Most of the statements, in the parts of this letter just quoted, Thurston knew were false.

Thurston also succeeded in having a proviso added to the fourth section of the bill, skillfully

${ }^{4 s}$ Set forth in Document J. 
worded, which forbade anyone claiming under the Donation Land Law to claim both under that law and under the treaty of 1846 , that treaty providing that possessory rights of British subjects should be respected. As Dr. McLoughlin had declared, in I 849 , his intentions to become a citizen and renounced his allegiance to Great Britain, he probably was no longer qualified to claim under the treaty. But even if he could have claimed under the treaty of 1846 , as a British subject, that would not have given him a right to obtain title to his land claim under that treaty. It was afterwards held by the Supreme Court of Oregon, in the case of Cowenia v. Hannah, 3 Oregon, 465, and by Judge M. P. Deady, sitting as United States Circuit Judge, in the case of Town v. De Haven, 5 Sawyer, 146 , that the stipulation in the treaty of 1846 that the United States would respect the possessory rights of British subjects, was merely a recognition of such possessory rights and conferred no right to, or in the land, and that no means were provided by the Donation Land Law, or otherwise, to obtain title or a patent, but a British subject might have a claim against the United States for compensation; that a claim to land, under the treaty, was to be excluded from any rights under the Donation Land Law, and a claim to land, under that law, was a surrender of possessory rights under the treaty. Unquestionably the Supreme Court of Oregon and Judge Deady were right in their construction of the law, as they found it, as applicable to the points involved in those cases. 
Article III of the Boundary Treaty of 1846 is as follows: "In the future appropriation of the territory south of the forty-ninth parallel of north latitude, as provided in the first article of this treaty, the possessory rights of the Hudson's Bay Company, and of all British subjects who may be already in the occupation of land or other property lawfully acquired within the said territory, shall be respected." Good faith, and to carry out the letter and the spirit of this Article III, should have caused Congress to respect these possessory rights of British subjects, so as to make them effective, and especially as they had acquired these rights under the Conventions for joint-occupancy of the Oregon Country. Means should have been provided in the Donation Land Law by which such British subjects "already in the occupation of land" in Oregon could have acquired the title thereto.

In the debate in the House of Representatives, May 28, I 850, on the bill which became the Oregon Donation Land Law, Thurston said: ${ }^{44}$ "This company [Hudson's Bay Company] has been warring against our government for these forty years. Dr. McLoughlin has been their chief fugleman, first to cheat our government out of the whole country, and next to prevent its settlement. He has driven men from claims and from the country, to stifle the efforts at settlement. In 1845 , he sent an express to Fort Hall, 800 miles, to warn the American emigrants that if they attempted to come

\footnotetext{
${ }^{44}$ Congressional Globe, Vol. 21, Part Second, p. 1079, first Session of 3 rst Congress.
} 
to Willamette they would all be cut off; they went, and none were cut off. How, sir, would you reward Benedict Arnold, were he living? He fought the battles of the country, yet by one act of treason forfeited the respect of that country. A bill for his relief would fail, I am sure; yet this bill proposes to reward those who are now, have been, and ever will be, more hostile to our country - more dangerous, because more hidden, more jesuitical. I can refer you to the Supreme Judge of our territory, for proof that this Dr. McLoughlin refuses to file his intention to become an American citizen." Judge Bryant was then in Washington, lobbying for the passage of the eleventh section of the Donation Land Law, particularly the part giving Abernethy's Island to the assigns of the Milling Company. I have already shown the falsity of these statements of Thurston in his letter and in this speech, by setting forth the truth in this monograph. The mention by Thurston, in his speech, of Benedict Arnold in comparison with Dr. McLoughlin, was contemptible. It was an insinuation which Thurston should have been ashamed to make.

On September 12, I850, Dr. McLoughlin published in the Oregon Spectator his answer to some of the statements, or rather misstatements, in Thurston's speech in Congress, May 28, I 850 , and in his letter to the House of Representatives. Dr. McLoughlin there said: "What Mr. Thurston means by 'warring against our government for these forty years,' I know not. I am certain, however, that the H. B. Co. had a right to carry on 
trade under the treaty of joint-occupation of the country - even were we to look no farther for another foundation of the right. I am sure, moreover, that the business of the Company was so managed as to bear the strictest scrutiny, and to be in all respects subservient to the best interests of the country, and the duties of religion and humanity.

But I am described as a 'fugleman' of the Hudson's Bay Company; first to cheat our Government out of the whole country, and next to prevent its settlement. I am an old man, and my head is very white with the frost of many winters, but I have never before been accused as a cheat. I was born a British subject - I have had for twenty years the superintendence of the Hudson's Bay Company's trade, in Oregon, and on the North West Coast; and may be said to have been the representative of British interests in this country; but I have never descended to court popularity, by pandering to prejudice, and doing wrong to any one. I have on the other hand, afforded every assistance to all who required it, and which religion and humanity dictated; and this community can say if I did so or not. . . . But, moreover, it is well known that the fact of my having aided in the settlement of this country has been a subject of serious complaints, and grave charges made against me, by subjects of Her Britannic Majesty, during the pending of the boundary question - who seem to have been imbued with the same kind disposition toward their fellow men as Mr. Thurston.

"Mr. Thurston says, 'In I 845 he [Dr. McLoughlin] sent an express to Fort Hall, eight hun- 
dred miles, to warn the immigration that if they attempted to come to the Willamette, they would be all cut off.' This is a calumny as gratuitous as it is unprovoked; but it is with mingled emotions of astonishment and indignation that I have accidentally become acquainted with the contents of another document, entitled a 'Letter of the Delegate from Oregon to the members of the House of Representatives, in behalf of his constituents, touching the Oregon Land Bill.' On the back of the only copy sent, is written in the handwriting of Mr. Thurston-'Keep this still till next mail, when I shall send them generally. The debate on the California Bill closes next Tuesday, when I hope to get it and passed - my land bill; keep dark till next mail.

"June 9, I850. Thurston."
". . . In the letter referred to, speaking of Oregon City, he says, 'The Methodist Mission first took the claim with the view of establishing here their Mills and Mission - they were forced to leave it under the fear of having the savages of Oregon let loose upon them.' This charge is likewise without a fraction of truth, as a few facts will demonstrate. . . Mr. Thurston is not ashamed to more than intimate a disposition to "let loose upon them savages of Oregon.' Mr. Thurston says, 'He has held it by violence and dint of threats up to this time.'-That I have held my claim or any part of it [Dr. McLoughlin's land claim] by violence or threats, no man will assert, and far less will one be found to swear so, who will be believed on his oath, in a court of justice. I have probably no other 
enemy than $\mathrm{Mr}$. Thurston, so lost to the suggestions of conscience as to make a statement so much at variance with my whole character. He says that I have realized, up to the 4 th of March, I $849, \$ 200$,ooo from the sale of lots; this is also wholly untrue. I have given away lots to the Methodists, Catholics, Presbyterians, Congregationalists, and Baptists. I have given 8 lots to a Roman Catholic Nunnery, 8 lots to the Clackamas Female Protestant Seminary, incorporated by the Oregon Legislature. The Trustees are all Protestants, although it is well known I am a Roman Catholic. In short, in one way and another I have donated to the county, to schools, to churches, and private individuals, more than three hundred town lots, and I never realized in cash $\$ 20$,ooo from all the original sales I have made. He continues, 'He is still an Englishman, still connected with the Hudson's Bay Company, and refuses to file his intentions to become an American citizen.' If I was an Englishman, I know no reason why I should not acknowledge it; but I am a Canadian by birth, and an Irishman by descent. I am neither ashamed of my birth-place or lineage. . . . I declared my intention to become an American citizen on the 3oth May, I849, as any one may see who will examine the records of the court, in this place. Mr. Thurston knew this fact - he asked me for my vote and influence. Why did he ask me for my vote if I had not one to give? I voted and voted against him, as he well knew, and as he seems well to remember. But he proceeds to refer to Judge Bryant for the truth of his statement, in which he affirms 
that I assigned to Judge Bryant, as a reason why I still refuse to declare my intention to become an American citizen, that I cannot do it without prejudicing my standing in England. I am astonished how the Supreme Judge could have made such a statementl as he had a letter from me pointing out my intention of becoming an American citizen. The cause, which led to my writing this letter, is that the island, called Abernethy's Island by Mr. Thurston, and which he proposes to donate to $\mathrm{Mr}$. Abernethy, his heirs and assigns, is the same island which Mr. Hathaway and others jumped in $184 \mathrm{I}$, and formed themselves into a joint stock company, and erected a saw and grist mill on it, as already stated. From a desire to preserve peace in the country, I deferred bringing the case to trial, till the government extended its jurisdiction over the country; but when it had done so, a few days after the arrival of Judge Bryant and before the courts were organized, Judge Bryant bought the island of George Abernethy, Esq., who had bought the stock of the other associates, and as the Island was in Judge Bryant's district, and as there was only two judges in the Territory, I thought I could not at the time bring the case to a satisfactory decision. I therefore deferred bringing the case forward to a time when the bench would be full.

But Mr. Thurston makes another statement in which there is not more truth. He says, 'Last summer he,' meaning myself, 'informed the writer of this that whatever was made out of the claim was to go to the common fund of the Hudson's Bay Company, of which he and other stock-holders 
would share in proportion to their stock; in other words, that he was holding this claim in trust for the Hudson's Bay Company.' . . . I assert I never made such a statement to Mr. Thurston, and I assert that I hold my claim for myself alone, and that the Hudson's Bay Company, nor no other person or persons, hold or have any interest in it with me. . . . Can the people of Oregon City and its vicinity believe $\mathrm{Mr}$. Thurston did not know, some months before he left this [territory], that Mr. Abernethy had sold his rights, whatever they were, to Judge Bryant, and therefore proposing to Congress to donate this Island to Mr. Abernethy, his heirs and assigns, was, in fact, proposing to donate it to Judge Bryant, his heirs and assigns." ${ }^{45}$

Thurston attempted to reply to this letter of Dr. McLoughlin, published in the Oregon Spectator, in a speech made in Congress December $26,185^{0^{46}}$ With all its false statements this speech utterly failed to justify the actions of Thurston against Dr. McLoughlin.

Lieutenant Neil M. Howison, of the United States Navy, came to Oregon in 1846 , in charge of the United States schooner "Shark." He made a report on Oregon to the Commander of the $\mathrm{Pa}$ cific squadron. The report is dated at San Francisco, February I, I847. It was printed by order of the House of Representatives, at Washington, in I 848, more than two years prior to Thurston's speech. It is Miscellaneous Document No. 29 of

${ }^{45}$ This letter of Dr. McLoughlin is set forth in full in Document

L. See also letter of William J. Berry, Document M.

${ }^{40}$ See Document N, where excerpts from this speech are set forth. 
the first session of the 3 oth Congress. In this report, after speaking in praise of Dr. McLoughlin, Howison said of him: "He resides now altogether at Oregon City . . . and has, by his advice and assistance, done more than any other man towards the rapid development of the resources of this country." Lieutenant Howison also said, in this report, that Dr. McLoughlin "has settled himself on the south side of the river [Columbia] with full expectation of becoming a citizen of the United States, and I hope the government at home will duly appreciate him."

In the report of Dr. Elijah White, dated Willamette Valley, Oregon, November 15, 1843, to J. M. Porter, Secretary of War, Dr. White said: "And here allow me to say, the seasonable service, in which hundreds of dollars were gratuitously expended in assisting such numbers of our poor emigrant citizens down the Columbia to the Willamette, entitles Gov. McLoughlin, saying nothing of his previous fatherly and fostering care of this colony, to the honorable consideration of the members of this government. And I hope, as he is desirous to settle with his family in this country, and has made a claim at the falls of the Willamette, his claim will be honored in such a manner as to make him conscious that we, as a nation, are not insensible to his numerous acts of benevolence and hospitality towards our countrymen. Sir, in the midst of slander, envy, jealousy, and, in too many instances, of the blackest ingratitude, his unceasing, never tiring hospitality affects me, and makes him appear in a widely different light than too 
many would have him and his worthy associates appear before the world." ${ }_{47}$

\section{Protests against Thurston's Actions.}

As shown in Dr. McLoughlin's printed letter of September I2, I850, Thurston had sent to a confidant in Oregon, with instructions for secrecy, a printed copy of his letter to the House of Representatives. He also sent a printed copy of the bill for the Donation Land Law. These arrived in Oregon late in August or early in September, 1850. The eleventh section of the latter began to be noised about, and Thurston's friends, who were not in the conspiracy, met the charge with scornful denials. They said such a thing was not possible. But it was. ${ }^{48}$ There were Oregon pioneers who protested. Before the law passed, when the intended action of Thurston became known, in relation to said section eleven, on September 19, I850, a public meeting was held in Oregon City. Resolutions were passed declaring that the selection of the Oregon City claim for an university reservation was uncalled for by any considerable portion of the citizens of the Territory, and was invidious and unjust to Dr. McLoughlin; and that he "merits the gratitude of multitudes of persons in Oregon for the timely and long-continued assistance rendered by him in the settlement of this Territory." At the same time a memorial to Congress was signed by fifty-six persons, which set forth that Dr. McLoughlin had taken up the Oregon

${ }^{47}$ White's Ten Years in Oregon, pp. 220, 221.

${ }^{48}$ Oregon Spectator, August 22 and 29, 1850. 
City claim like other claims in the Territory, and it had been held by him in accordance with the Provisional and Territorial governments of Oregon; that the memorialists have ever regarded it as entitled to protection as fully as other claims, without an intimation to the contrary from any official source until that time; that under this impression, both before and especially since March 4, 1849, large portions of it in blocks and lots had been purchased in good faith by many citizens of Oregon, who had erected valuable buildings thereon, in many instances, in the expectation of having a complete and sufficient title when Congress should grant a title to Dr. McLoughlin, as was confidently expected; that since March 4, 1849, he had donated for county, educational, charitable, and religious purposes more than two hundred lots. They, therefore, remonstrated against the passage of the bill in its present form, believing that it would work a "severe, inequitable, unnecessary, and irremediable injustice." ${ }^{49}$ There were no telegraph lines in Oregon or California in those days. And the bill was a law eight days thereafter.

I am happy to say that among those who took part in these proceedings and signed this memorial were my father, James D. Holman, a pioneer of 1846 , and my uncle, Woodford C. Holman, a pioneer of 1845 . October 26,1850 , a public meeting was held at Salem, the stronghold of the Mission Party. At this meeting a committee on resolutions was appointed. The resolutions reported

${ }^{40}$ Oregon Spectator, September 26, 1850. 
by the committee were adopted. They "highly approved all the actions of Samuel R. Thurston in Congress," and said "that facts well known in Oregon will sustain him in all he has said about Dr. McLoughlin and the H. B. Company." Another of these resolutions heartily approved the course taken by Thurston, in Congress upon the Donation Land Bill "especially that part which relates to the Oregon City claim," and "that if that claim should be secured to Dr. McLoughlin it would, in effect, be donating land to the H. B. Company." Another of these resolutions was, "That in the opinion of this meeting, the children of Oregon have a better right to the balance of that claim [Oregon City claim] than Dr. McLoughlin." Another of these resolutions was, "That the H. B. Company, with Dr. McLoughlin as their fugleman, have used every means that could be invented by avarice, duplicity, cunning, and deception to retard American settlement, and cripple the growth of American interests in Oregon." ${ }^{0}$

There are certain qualities in some men which move them never to forgive a favor bestowed on them; to ruin those they have wronged or cheated; to endeavor to cover with obloquy those they have lied about; and to seek to hurt any one of better quality than they are. As a native son of Oregon I am ashamed of some of its pioneers and their actions. But in such a movement as the early settling of Oregon, there were, of necessity, some men of coarse fiber, and of doubtful integrity and honor. But such men were rare exceptions. To

\footnotetext{
${ }^{50}$ Oregon Spectator, November 7, 1850.
} 
the honor of the overwhelming majority of the Oregon pioneers, be it said that they took no part in these actions against Dr. McLoughlin, nor did they endorse or sympathize with 'Thurston's actions and those of his co-conspirators against Dr. McLoughlin.

It must be borne in mind that many thousands of people, men, women, and children, came to Oregon in the immigrations after 1846 . There were probably in the immigrations of 1847 to $185^{\circ}$, inclusive, an aggregate of more than ten thousand people, the number of men being in the ratio of about one to four. The immigration of 1847 was composed of over four thousand persons. These later immigrants did not experience the difficulties which beset the earlier immigrants along the $\mathrm{Co}$ lumbia River and from there to the Willamette Valley. They did not need the assistance of Dr. McLoughlin which the immigrants of 1843,1844 , and 1845 did. They found Oregon City a small but thriving settlement. Some of them were easily led to believe that Dr. McLoughlin was not entitled to his land claim, which they thought was a valuable one, especially as he was technically a British subject. But most of them were friendly to him for his kindness to them, and for what he had done for the earlier immigrants. They appreciated that he was justly entitled to his land claim. The love of justice and fair play were predominant traits of most Oregon pioneers.

The Oregon Donation Land Law.

The Donation Land Law passed and was ap- 
proved by the President September 27, 1850. Section 4 "granted to every white settler or occupant of the public lands, American half-breed Indians included, above the age of eighteen years, being a citizen of the United States, or having made a declaration, according to law, of his intention to become a citizen, or who shall make such declaration on or before the first day of December, eighteen hundred and fifty-one, now residing in such territory, or who shall become a resident thereof on or before the first day of December, 1850, and who shall have resided upon and cultivated the same for four consecutive years, and shall otherwise conform to the provisions of this act," 320 acres of land, if a single man, or if a married man, 640 acres, 320 acres being for his wife. The last sentence of Section 4 is as follows: "Provided further, however, that this section shall not be so construed as to allow those claiming rights under the treaty with Great Britain, relative to the Oregon territory, to claim both under this grant and the treaty, but merely to secure them the election and confine them to a single grant of land."

Section eleven of said Donation Law is as follows: "Sec. I1. And be it further enacted, That what is known as the 'Oregon City Claim,' excepting the Abernethy Island, which is hereby confirmed to the legal assigns of the Willamette Milling and Trading Companies, shall be set apart and be at the disposal, of the Legislative Assembly, the proceeds thereof to be applied, by said Legislative Assembly, to the establishment and endowment of a university, to be located at such place in the ter- 
ritory as the Legislative Assembly may designate; Provided, however, That all lots and parts of lots in said claim, sold or granted by Doctor John McLoughlin, previous to the fourth of March, eighteen hundred and forty-nine, shall be confirmed to the purchaser or donee, or their assigns, to be certified to the commissioner of the general land office by the surveyor-general, and patents to issue on said certificates, as in other cases: Provided, further, That nothing in this act contained shall be so construed and executed as in any way to destroy or affect any rights to land in said territory, holden or claimed under the provisions of the treaty or treaties existing between this country and Great Britain." By the "Oregon City claim" is meant Dr. McLoughlin's land claim.

This section eleven is unjust in its treatment of Dr. McLoughlin. Not that Congress was to blame. It did not know the facts. Did not the first Delegate from Oregon advocate it? Did not the first Territorial Chief Justice of Oregon then in Washington, advise it? And did not the Delegate and the Chief Justice say that Dr. McLoughlin was so dangerous and unprincipled a man as not be entitled to his land claim? And that he refused to become an American citizen? There was not even a recognition of Dr. McLoughlin's right to the improvements which he had placed on his land claim. And there, in all its infamy, said section eleven stands on the statute books today. If the assigns of the Milling Company were entitled to Abernethy Island, why should not the courts have settled the 
matter according to law and justice, as other contested land claims were settled?

\section{The Conspiracy Effective.}

The motives and scheme of the conspirators to deprive Dr. McLoughlin of his land claim were very simple but effective. They desired to obtain Abernethy Island, which was a part of Dr. McLoughlin's land claim, for the assigns of the Oregon Milling Company. They desired to deprive Dr. McLoughlin of the rest of his land claim to wreak their malice against him, and at the same time, by statute passed by Congress, to have their actions against him apparently justified. Theirs was an uneasy conscience. It was, therefore, necessary to make it appear to Congress that Dr. McLoughlin was not orly not entitled to his land claim nor any part of it, but that he should not have it under any circumstances; that Dr. McLoughlin was a man dangerous to Oregon, its people, and their interests, and had unfairly tried to prevent its settlement by citizens of the United States; that he refused to become an American citizen; and that he was not really trying to get the land claim for himself, but for the Hudson's Bay Company, although they knew his resignation had become effective in 1846 . Having so wronged Dr. McLoughlin, they still did not dare to try to get the whole claim. To keep Dr. McLoughlin, or his heirs, from ever getting it, they tried to bribe the people of Oregon by providing that his land claim, less Abernethy Island, should be used for the establishment of an university, which would 
be for the benefit of all the people of Oregon. It was a cunning scheme. Thurston's reward was to be a re-election as Delegate to Congress. He died before he could be re-elected.

There was great rejoicing in Oregon, at first, on the passage of the Donation Land Law. Every settler, except Dr. McLoughlin, could now have his land claim, for the title to which he had waited so long. A great university was to be built, without cost to anyone, except Dr. McLoughlin and his heirs. This was long before the discussion about using "tainted money." But the reaction against Thurston soon began. The newspapers printed letters against Thurston's actions in vilifying Dr. McLoughlin and in taking away his land claim. Thurston's party papers began to mention or to advocate other available men ${ }^{51}$ for Thurston's position as delegate to Congress. ${ }^{52}$

\section{Career and Death of Thurston.}

Even had the Mission Party, at the next election, been strong enough to have elected Thurston, had he lived, his political career would probably not have continued long. April 9, 185 I, at the age of thirty-five years he died at sea off Acapulco, Mexico, while returning to Oregon. Thurston's letter, speeches, and actions against Dr. McLoughlin are the one great blot on his career. Thurston was a man of ability, a fluent speaker, a profuse writer

\footnotetext{
1851 .

${ }^{51}$ Western Star (Milwaukee, Oregon) February 20, and March $\mathrm{I}_{3}$,

${ }^{52}$ Attention is called to the correspondence of S. R. Thurston, Nathaniel J. Wyeth, R. C. Winthrop and Dr. McLoughlin, which is set forth in Document $\mathrm{O}$.
} 
of letters, of untiring energy, but inclined to be vindictive, and was not careful about the truth of his statements concerning a person he opposed or disliked. He made quite a reputation during the short time he was in Congress. He was quite popular in Oregon until his actions against Dr. McLoughlin became known. But for his actions against Dr. McLoughlin his memory would even now be highly regarded in Oregon. The passage of the Donation Land Law was largely due to his efforts. In spite of said section eleven that law. gave great satisfaction to many people in Oregon. Up to that time no settler had more than a squatter's right. Man is naturally selfish. Notwithstanding the treatment of Dr. McLoughlin by this law, many settlers were pleased that they could now secure titles to their lands, and to that extent were grateful to Thurston.

Thurston secured appropriations for Oregon aggregating one hundred and ninety thousand dollars. Of this one hundred thousand dollars were for expenses of the Cayuse Indian War. He introduced and worked for many bills favorable to Oregon and busied himself in looking after the interests of Oregon and his constituents. He wrote a great number of letters, which were published in the Oregon Spectator, calling attention to what he was doing in Congress and thus kept his name continuously before the people, for he was a skillful politician. But his alliance with leaders of the Mission Party was a political error.

This address is about Dr. McLoughlin. I have not attempted to give the life of Thurston, nor a 
history of the Methodist Mission. To speak only of Thurston's actions against Dr. McLoughlin might be taken to mean that Thurston did nothing else while in Congress. In estimating Thurston's actions in Congress, those that are to his credit must be taken into account as well as those which are not. His actions in regard to Dr. McLoughlin's land claim were an unfortunate bid for popularity, which reacted on him and his reputation. Thurston's untrue and unjust statements, his despicable actions, and his false and malicious charges against Dr. McLoughlin are indefensible. Thurston's untimely death probably prevented justice being done to Dr. McLoughlin and his devisees sooner than it was. Thurston was not a strong man physically and it was thought that he had shortened his life in working for Oregon and his constituents. To act justly to the living Dr. McLoughlin, in a certain sense, might be construed as reflecting on the dead Thurston.

\section{The Methodist Episcopal Church.}

All my ancestors and relatives for many generations have been Protestants. I was brought up under the auspices of the Old School Presbyterian Church, of which my parents were members from my early childhood until their deaths at advanced ages. I have never been a member of any church, but my feelings and sympathies have always been that of a Protestant. I respect all true sects and denominations of the great Christian Church. I respect the religion of the Jews, of Buddha, and of Confucius, for the good that is in them. I respect 
every man's religious faith, as long as it is truly a religious faith. I uphold the right of every man to worship God according to his liking. I respect, I admire, the man who against opposition and against his material and business interests follows the dictates of his conscience in religious and other matters of principle. While I may not agree with him, I defend his right. It is immaterial to me whether Dr. McLoughlin was a Protestant or a Roman Catholic. It is sufficient to me that he honestly acted according to his reason, his judgment, and what he considered was right. I condemn any persecution of him for being true to his conscience. I have great admiration for the Methodist missionaries who were true to their principles, who tried to lead blameless lives and to convert the Indians, and respected the rights of others. It is immaterial to me whether the missionaries were Methodists, Presbyterians, Congregationalists, or Roman Catholics, so long as they were really missionaries and true to their God, according to their lights, true to their professions, to themselves, and to their fellow men. I have no attack to make on religion, nor on the Methodist Episcopal Church, nor on its true missionaries, clerical or lay.

The Methodist Episcopal Church has been one of the great civilizing agencies in the United States, particularly in the newer parts of the country. In its earlier days, and until the great growth of the country in the past forty or fifty years, it reached a class of people, which no other denomination could reach or influence, and made better 
people of them. All churches and denominations are subject to conditions and to evolution. And the Methodist Episcopal Church is today one of the great and influential churches in the United States.

There always have been and there always will be men who make use of religion for sinister purposes. These unworthy missionaries who were parties to the unjust treatment of Dr. McLoughlin are not entitled to escape criticism, nor to have their wrongful acts passed over because of their religious pretentions. They are subject all the more to severe condemnation. All good Methodists condemn those wrongful acts of the missionaries as all true, honest Oregon pioneers condemn the acts of the pioneers who abused or cheated Dr. McLoughlin. But these base actions were not sustained by, nor concurred in by all the Methodist missionaries. Some condemned these actions. Others of these missionaries, appreciating what Dr. McLoughlin had done for them, and his humanitarianism, spoke in his praise, but did not break with their fellows who were persecuting Dr. McLoughlin. Some of the signers of the Shortess petition afterwards regretted, or were ashamed of their actions in so doing. Some timid persons may say that it would be better, in this address, merely to speak of the kind acts and high character of Dr. McLoughlin and not of the wrongful and unjust ways in which he was treated by some of the early immigrants, by some of the Methodist missionaries, by Thurston, by Bryant, and others. But that would not show what he suffered for the upbuilding of Oregon, nor his mar- 
tyrdom on account of his humanity, of his principles, and of his integrity. It would not be a true, nor an accurate account of his life and time.

Some persons in writing a life of Jesus would speak of his gentleness, his kindness, and his humanity, and say no more. They would not say anything against the Pharisees, nor of their condemnation by Jesus, because the Pharisees were people of some standing in their community, and did some kindly acts, and for fear of offending the descendants of the Pharisees. Such historians would not say anything against Caiaphas, the high priest, nor his actions against Jesus, because they might offend those religiously inclined. They would not say anything against those who cried "Crucify him," in their religious zeal. They would not say anything against Pontius Pilate, for fear of being thought to have attacked the Judiciary. They would either omit the crucifixion or merely say the last days of Jesus were passed somewhat in sorrow and in pain. But such a history would be trivial, and of no value. It would fail to show what Jesus did and suffered in his endeavors to help mankind. It would be a history in name only.

\section{Dr. McLoughlin's Memorial to Congress.}

By the passage of the Donation Land Law, and also by reason of the letter and of the speeches of Thurston in Congress, Dr. McLoughlin was put in the humiliating position of having to issue a printed circular letter to get expressions of opinions of others, as to the falsity of the charges made 
against him by Thurston, and to support a memorial to Congress which Dr. McLoughlin afterwards sent to Congress with all the evidence. But his memorial accomplished nothing. There was, too, the question that Congress had given away his land claim, which was then technically the property of Oregon, for an university, and that Congress could not, with dignity to itself, revoke its gift. And who was Dr. McLoughlin to Congress? He was away out in Oregon nearly 4,000 miles from Washington. There were great and serious matters to be considered by Congress. The Oregon question was settled. What were the wrongs and misfortunes of one old man to Congress?

In answer to the printed circular issued by Dr. McLoughlin, after the passage of the Donation Land Law, for the purposes of his memorial to Congress, he received many commendatory letters. I give merely excerpts from the letter of that noble old pioneer, Jesse Applegate, an immigrant of I843. He wrote: "I have received your letter of inquiries, and take pleasure in replying to such of them as I personally know to be true. I came to this country in the fall of 1843 , and, from that time forward, I can safely testify that your conduct has been the most generous and philanthropic, not only to immigrants from the United States, but to all requiring your assistance, whether natives or foreigners. I can also say that you have greatly encouraged and given much assistance in settling and developing the resources of the country, but $I$ have by no means considered your motive for doing so political, or that your charitable acts were intended 
to advance the interests of any particular nation, but that you acted in the one case simply from a sense of Christian duty and humanity, and in the other from a natural desire to be useful in your day and generation. . . . But as the office of Chief Factor of the Hudson's Bay Company is in no way connected with politics, the discharge of its duties imposed no restrictions upon your private sentiments, and unless they led to a betrayal of your trust, which has never been charged against you, as an Irishman and a Catholic, you were free to feel and express your partiality for the free and tolerant institutions of the United States. That you did entertain such partiality, from my first acquaintance with you, need not depend upon my assertion, for it is a fact well known, and one you did not pretend to conceal."

Jesse Applegate then says, in this letter, that he was present in 1845 when Dr. McLoughlin applied to Judge Peter H. Burnett, the Chief Justice of the Provisional Government, to take the oath of allegiance to the United States and to obtain first naturalization papers, but Judge Burnett declined to grant the request for he believed he did not have any jurisdiction to do so. Jesse Applegate further said in his letter: "That 'you pulled down houses and turned women and children out of them,' is a charge not only false, but too absurd to require refutation or notice. I can myself state from experience, which accords with that of every other destitute immigrant who applied to you for assistance, either before or since my arrival in the country, that your conduct was entirely the re- 
verse. My own company, of more than seventy persons, mostly women and children, who arrived at Vancouver in the storms of winter, in a condition the most destitute and miserable, were received by you, not as strangers, or foreigners, or as some would have it, enemies, but as brethren and fit subjects of hospitality and Christian charity, and our reception was not more kind and generous than was extended to every immigrant who sought your hospitality or assistance.

But however unjust the Oregon Land Law has been towards you, it may be said in excuse for the members of Congress who passed it, that with the concurring and uncontradicted evidence of the Delegate and Chief Justice of Oregon before them, you neither had nor would become an American citizen, they are not chargeable with injustice." 53

\section{The Persecution Continued.}

The conspirators and their friends did not cease their persecution of Dr. McLoughlin. They were determined he should not have his land claim. To protect the reputation of Thurston and the other conspirators, it was necessary to defeat all actions of the Oregon Legislative Assembly in favor of Dr. McLoughlin. If that body made any petitions to Congress or passed any resolutions in favor of Dr. McLoughlin, it would show that he was entitled to his land claim, the injustice of section eleven of the Donation Land Law, and that Thurston was guilty of malicious untruths in his letter to, and his speeches before Congress relating ${ }^{53}$ See Document $P$. 
to Dr. McLoughlin and his land claim. Oregon could not, with propriety, pretend to act justly to Dr. McLoughlin and still retain his land claim. I regret to say that the House of Representatives of the Oregon Legislative Assembly, at its session in $1853-4$, not only refused to help Dr. McLoughlin, but by its actions did him harm. January 6 , I 854 , several petitions were presented to the House asking that Congress be memorialized in favor of Dr. McLoughlin's right to his land claim, "excepting the Abernethy Island," but the petitions were immediately laid on the table. January 28 , 1854 , Orlando Humason presented to the House the following resolution: "Whereas, the acts of John McLoughlin in regard to his treatment of the early settlers of Oregon, have, as we believe, been misrepresented, therefore-RESOLVED, that the generous conduct of Dr. John McLoughlin in assisting the early settlers of Oregon, merits our warmest commendations, and that as evidence of the high estimation in which his services are held by his fellow citizens, the thanks of this Assembly be tendered to the said Dr. John McLoughlin." ${ }^{44}$ But by the vote of sixteen to seven, three being absent, the resolution was indefinitely postponed, which was the legislative way of defeating it. All honor to the seven who voted in favor of the resolution. Their names are F. C. Cason, L. F. Cartee, Orlando Humason, B. B. Jackson, J. W. Moffitt, Chauncey Nye, and L. S. Thompson.

${ }^{5}$ House Journal, 1853-54, p. 65. 
The End of Dr. McLoughlin's Life.

All these troubles and tribulations naturally told on Dr. McLoughlin. He was a man of fortitude, who brooded, almost silently, over his sorrows, with an occasional outburst when his sufferings were too intense. He had made expensive improvements on his land claim, including a flour-mill and a saw-mill, and other buildings. No provisions were ever made by Congress to pay for these improvements. Even his dwelling house at Oregon City, which for several years had been the home of himself and his family, was taken from him, with his other improvements, by section eleven of the Oregon Donation Land Law. It is true he remained in possession of these improvements, including his home, but by sufferance only. Because the Territory of Oregon did not sell the land he was not actually ousted. There was no way to acquire land in Oregon City, taken from Dr. McLoughlin by said section eleven, except by a law passed by the Oregon Legislature. And the legislature did nothing.

He could not move nor sell his improvements. They belonged to the land on which they were erected. Even if he could have sold them they would have brought but little as they would have to be moved. His mills were erected to be run by water power and they were conveniently situated on the bank of the river near the falls, for the economical handling of wheat and logs and the shipping of products of these mills. They could not, at that time, be successful financially if they were moved and operated by steam. He 
hoped that Congress or the Legislature would restore his land claim to him. But he hoped and waited in vain. The lion was entangled in a net. He struggled but he could not escape. And so Dr. McLoughlin became straitened financially. Had Dr. McLoughlin been allowed to have his land, he could then have built up a large town at Oregon City. As it was, investors went to places where titles to land could be obtained and there built up enterprises. With the moneys from the sale of land Dr. McLoughlin could have paid the Hudson's Bay Company all the moneys due by settlers, who had failed or refused to pay. The payment of this heavy indebtedness Dr. McLoughlin had assumed. It was a matter of honor with him. He owed nothing else to the Hudson's Bay Company. The settlers who would not pay their indebtedness caused Dr. McLoughlin to feel keenly their ingratitude. If they had paid him, he would have paid the Company in full.

And there, too, was the question of providing after his death for his loving and faithful wife, to whom he was devoted, and his children. He had always been generous to his family. He had provided for his mother until her death at the age of eighty-three years. He had educated four nieces. He had helped other of his relatives. Is it to be wondered at that he sometimes felt bitter?

The McLoughlin Document was undoubtedly written at this period. It is a brief of his defense. He probably wrote it so that his descendants would understand. At the end of this Document, Dr. McLoughlin said: "By British demagogues I have 
been represented as a traitor. For what? Because I acted as a Christian; saved American citizens, men, women and children from the Indian tomahawk and enabled them to make farms to support their families. ${ }^{55}$ American demagogues have been base enough to assert that I had caused American citizens to be massacred by hundreds by the savages. I, who saved all I could. I have been represented by the Delegate from Oregon, the late S. R. Thurston, as doing all I could to prevent the settling [of Oregon], while it was well known to every American settler who is acquainted with the history of the Territory if this is not a downright falsehood, and most certainly will say, that he most firmly believes that I did all I could to promote its settlement, and that I could not have done more for the settlers if they had been my brothers and sisters, and, after being the first person to take a claim in the country and assisting the immigrants as I have, my claim is reserved, after having expended all the means I had to improve it, while every other settler in the country gets his. But as I felt convinced that any disturbance between us here might lead to a war between Great Britain and the States, I felt it my bounden duty as a Christian, to act as I did, and which I think averted the evil, and which was so displeasing to some English demagogues that they represented me to the British government as a person so partial to American interests as selling the Hudson's Bay Company goods, in my charge, cheaper to Amer-

${ }^{55}$ See Document $Q$. 
ican than I did to British subjects. after acting as $I$ have, spending my means and doing my utmost to settle the country, my claim is reserved, while every other settler in the country gets his; and how much this has injured me, is daily injuring me, it is needless to say, and certainly it is a treatment I do not deserve and which I did not expect. To be brief, I founded this settlement and prevented a war between the United States and Great Britain, and for doing this peaceably and quietly, I was treated by the British in such a manner that from self respect I resigned my situation in the Hudson's Bay Company's service, by which I sacrificed $\$ 12,000$ per annum, and the 'Oregon Land Bill' shows the treatment I received from the Americans."

And so, worried and troubled without surcease, Dr. McLoughlin maintained his grand, but kindly, attitude to the last. But these matters affected his health. For several years before his death he was an invalid, but his pride assisted him to persevere and to transact such business as he could, although his heart was breaking. His flesh became greatly reduced, his eyes deeply sunken. He grew so emaciated that his great frame stood out, making him look gaunt and grim. For a few weeks, only, before his death he was confined to his bed.

Thus encompassed and overcome, and crucified by robbery, mendacity, and ingratitude, Dr. John McLoughlin died at Oregon City, September 3, I 857 , a broken-heartec' man. He was buried in the churchyard of the Roman Catholic Church in Oregon City, where his body now lies. The stone 
which marks his grave bears the simple inscription:

"DR. JOHN MCLOUghLiN

DIED

Sept. 3, 1857 .

AGED

73 Years.

The pioneer and Friend of Oregon.

Also the founder of this City."

Dr. John McLoughlin is not the only great character in history, whose memory shall live for all time, but whose death was under sad circumstances and whose heart, at the time of his death, was then filled with thoughts of the wrong-doings and the ingratitude of others.

The frontispiece to this address is made from a photograph of a daguerreotype of Dr. McLoughlin taken in 1856 , when his sorrows and tribulations were beginning to tell on him. This daguerreotype belongs to Mrs. Josiah Myrick, of Portland, Oregon, who is a granddaughter of Dr. McLoughlin. She kindly loaned this daguerreotype to have the photograph made of it.

Governor L. F. Grover was elected Governor of Oregon for two consecutive terms. He resigned during his last term to be an United States Senator, to which latter office he was elected. $\mathrm{He}$ is now living in Portland, at an advanced age. On the fourteenth of September, 1905, he gave me a written statement of an incident which occurred in the last sickness of Dr. McLoughlin. In this statement Governor Grover said that he was riding on horseback through Oregon City on his way from 
Salem to Portland, and passed down the street directly in front of Dr. McLoughlin's home, a few days before his death. As Governor Grover was giving directions for the care of his horse, a messenger came to him from Dr. McLoughlin requesting Governor Grover to call at $\mathrm{Dr}$. McLoughlin's house. Governor Grover says: "I found him extremely ill. . . He said that he was dying by inches. He said: 'I shall live but a little while longer and this is the reason I sent for you. I am an old man and just dying, and you are a young man and will live many years in this country, and will have something to do with affairs here. As for me, I might better have been shot'and he brought it out harshly -'I might better have been shot forty years ago.' After a silence, for I did not say anything, he concluded: 'than to have lived here and tried to build up a family and an estate in this government. I became a citizen of the United States in good faith. I planted all I had here and the government has confiscated my property. Now what I want to ask of you is that you will give your influence after I am dead to have this property go to my children. I have earned it as other settlers have earned theirs, and it ought to be mine and my heirs.' I told him I would favor his request, and did."

Justice to Dr. McLoughlin's Memory.

Although the Donation Land Law went into effect September 27, 1850, and its section eleven provided that the "Oregon City Claim" should be at the disposal of the Territory for the establishment 
and endowment of an university, nothing was done with this land claim until 1862 , three years after Oregon became a state. In October, 1862, the Legislative Assembly of the State of Oregon passed an act, which was approved by the Governor October I7, 1862, conveying and confirming to the legatees under the will of Dr. McLoughlin, who were his son, David, his daughter, Eloisa, and her husband, Daniel Harvey, the McLoughlin or Oregon City land claim, excepting Abernethy Island, upon the condition that said legatees pay to the University Fund of Oregon, the nominal sum of one thousand dollars. This was forthwith paid by Daniel Harvey and wife in gold coin although they might have paid it in greenbacks, which were then at a large discount. As the eleventh section of the Donation Land Law provided that the proceeds of the sale of said Oregon City Claim should be applied to the establishment and endowment of an university, there had to be some consideration paid on its disposal by the State. All this occurred twelve years after the passage of the Donation Land Law and five years after the death of Dr. McLoughlin. During all those twelve years the title of this land claim was in the Territory, or State of Oregon. It stopped the growth of Oregon City. It impoverished Dr. McLoughlin.

As appears by the Senate and House Journals of the Legislative Session of 1862 said act passed the Senate, with two negative votes only, and there were none in the House after the act was amended in the Senate in the form in which the act became a law. The injustice of the Donation Land Law 
to Dr. McLoughlin had appealed to the people of Oregon in the twelve years which had elapsed since the passage of the latter law. What Dr. McLoughlin had done for Oregon and its pioneers could not be forgotten. Justice to him and his memory was, at last, triumphant. The enactment and approval of this law of October 17, 1862, was an official vindication of Dr. McLoughlin, by the Legislative and Executive Departments of the State of Oregon, of all the false statements about, and all charges against him made by Thurston and others, and of all their misrepresentations of Dr. McLoughlin and of his acts. It was a formal official acknowledgment of the injustice of the Oregon Donation Land Law to Dr. McLoughlin. It was an official recognition of his sterling qualities; of his humanity; of his great services in assisting the early immigrants; of what he had done for Oregon; and of what was due to him and to his memory as the Father of Oregon. It cleared his character and reputation from every imputation of unfairness, injustice, and chicanery. It was, in effect, an official condemnation of the acts of the conspirators against him.

In 1846 the fame of Dr. John McLoughlin as a great and good man had extended to Rome. That year Gregory XVI, then the Pope, made Dr. McLoughlin a Knight of St. Gregory the Great, of civil grade. The original patent, written in Latin, is now in the possession of a descendant of Dr. McLoughlin. A copy in English is in the possession of the Oregon Historical Society. The Pope sent to Dr. McLoughlin the Insignia of the 
Order, which was delivered to him by Archbishop Francis N. Blanchet on his return from Europe in August, r847. It was a high and deserved honor. But without it Dr. John McLoughlin was one of Nature's knights in all qualities which the highest and best of knights should have. He was such a knight, sans peur, sans reproche.

Opinions by Dr. McLoughlin's Contemporaries.

In 1887 the people of Portland determined to raise six hundred dollars for a three-quarter lifesize portrait of Dr. McLoughlin, to be painted by William Coggswell, the artist, to be owned by the Oregon Pioneer Association. The money was raised by popular subscription. The total amount subscribed was nearly double the sum required. This portrait was formally presented to the Association at its annual meeting, June I 5, I887. Judge M. P. Deady made the presentation address. He was a judge for forty years continuously in Oregon. A part of the time, six years, he was on the Oregon Territorial Supreme Bench, and for thirtyfour years he was United States District Judge for Oregon, after Oregon became a State. In his presentation address Judge Deady, speaking of Dr. McLoughlin, ${ }^{56}$ said: "The man, whose portrait now hangs before you, came to this country from the Atlantic commissioned as Chief Factor and Governor of the Hudson's Bay Company west of the Rocky mountains. He was clothed with absolute power. . . He was the ruler of this country, and had the peace and security of the peo-

\footnotetext{
${ }^{56}$ Transactions of the Oregon Pioneer Association for 1887, p. 16.
} 
ple in his hands. He was distinguished for his justice and fair dealing with the Indians. When the immigration came he was distinguished for kindness and hospitality. He always literally obeyed the scriptural injunction to feed the hungry, visit the sick and clothe the naked. The maintenance of law, order and justice rested on his shoulders and he was equal to the occasion.

"The people of Portland have thought to honor his memory by having his portrait painted and giving it to the Pioneer Association, to be taken to the fair city of Salem and hung in the State Capitol, where you may look at it and show it to your children, and they to their children, and say: 'This is the old doctor, the good doctor, Dr. John McLoughlin.' 'Thirty years ago he laid down his life at the Wallamet Falls, where he had builded and lived since 1845 , somewhat in obscurity, somewhat in sorrow, somewhat in sadness and disappointment. But the political strife and religious bigotry which cast a cloud over his latter days have passed away, and his memory and figure have arisen from the mist and smoke of controversy, and he stands out today in bold relief, as the first man in the history of this country-the Pioneer of Pioneers."

The Oregon Pioneer Association deemed it best to present this portrait to the State of Oregon. This was done February 6, 1889, at a joint session of the Senate and House of the Oregon Legislative Assembly held for the purpose. This portrait now hangs in the Senate chamber of the State Capitol at Salem in the place of honor, immediately back 
of the chair of the President of the Senate. John Minto, an honored pioneer of 1844 , was selected to make the presentation address. In this address Mr. Minto said: ${ }^{57}$ "In this sad summary of such a life as Dr. McLoughlin's, there is a statement that merits our attention, which, if ever proven true and no man that ever knew Dr. McLoughlin will doubt that he believed it true, namely, that he prevented war between Great Britain and the United States - will show that two of the greatest nations on this earth owe him a debt of gratitude, and that Oregon in particular is doubly bound to him as a public benefactor. . . . It is now twenty-six years since the Legislative Assembly of the State of Oregon, so far as restoration of property to Dr. McLoughlin's family could undo the wrong of Oregon's land bill, gave gladness to the heart of every Oregon pioneer worthy of the name. All of them yet living now know that (good man as they believed him) he was better than they knew. They see him now, after the strife and jealousies of race, national, business, and sectarian interests are allayed, standing in the centre of all these causes of contention - a position in which to please all parties was simply impossible, to maintain which 'only a good man could bear with patience' - and they have adopted this means of conveying their appreciation of this great forbearance and patient endurance, combined with his generous conduct. Looking, then, at this line of action in the light of the merest glimpses of history known to be true by witnesses yet living, can any honest man wonder

\footnotetext{
${ }^{57}$ Transactions of the Oregon Pioneer Association for 1888, p. I34.
} 
that the pioneers of Oregon, who have eaten the salt of this man's hospitality - who have been eye witnesses to his brave care for humanity and participators of his generous aid - are unwilling to go to their graves in silence, which would imply base ingratitude - a silence which would be eloquent with falsehood?"

In accepting this portrait, on behalf of the State of Oregon, Gov. Sylvester Pennoyer, also an Oregon pioneer, who served two consecutive terms as Governor of the State of Oregon, said: ${ }^{58}$ "This gift is alike creditable to the venerable men of your Association in its bestowment and to the State of Oregon in its acceptance. It does honor to the pioneers of Oregon, because it shows their full appreciation of the high qualities of a true and noble manhood; and the placing of this painting in the honorable position it now occupies in the senate-hall of the state capitol evinces a like appreciation on the part of the representatives and the people of this great State. Dr. McLoughlin was, indeed, a most extraordinary man. Entrusted with a most responsible position under the British flag at a time when there was a bitter contest for governmental supremacy in Oregon, it was the undoubted and honorable wish and prompting of his heart that the flag of his country might continue to wave over Oregon soil, and yet in instances repeated without number, he extended the hand of charity and unstinted aid to the poor immigrants of the contesting people, whose advent here threat136.

${ }^{88}$ Transactions of the Oregon Pioneer Association for 1888, pp. 135, 
ened the supremacy of his government over the contested territory. While he was loyal to his country he was, as became his lofty character, more loyal to his conscience; and while never forgetting his full allegiance as a Briton, he never forgot his higher duty as a man. . . . Then let this picture of the grand old man, whose numerous deeds of charity are inseparably interwoven in the early history of our State, ever enjoy the place of honor it now holds; and when our children and our children's children shall visit these venerated halls, let them pause before the portrait of this venerable man and do homage to his memory, who, with his patriotic devotion to his country and his devout service to his God, crowned the full completeness of his high character with an unmeasured love for his fellow men."

I have already spoken of the Rev. H. K. Hines, D.D., a Methodist minister who came to Oregon in 1853 , and of his memorable address delivered at Pendleton, December I0, I897. In this address Dr. Hines said that "Dr. McLoughlin should escape the traduction of sectarian rancor and bigotry, . was perhaps an impossibility. $\mathrm{He}$ certainly did not. Of course all could see at the outset, and none more clearly than the missionaries themselves, that the attitude he assumed towards the American missions and missionaries, must needs decide the success of their work, and even the very inauguration of it. . . . Dr. McLoughlin was a Christian, professedly, and it does not lie in me to say that he was not really and truly. At this time, and long before, and for 
years afterwards, he was a member of the Church of England. That subsequently, in 184 I, I think, he became a devout member of the Roman Catholic church, does not, to my mind, take from or add to the estimate I make of him as a devout believer in that form of religion called Christianity." And speaking of Dr. McLoughlin's treatment of the missionaries of all denominations, Dr. Hines said: "All these missionaries came while Dr. McLoughlin was not connected with any of the churches they represented. His treatment of them was on a broader and higher plane than that of the sectary. It was that of the humanitarian and the Christian, and it continued thus even after he must have seen that, at least, the missions of $\mathrm{Mr}$. Lee and Dr. Whitman were, in the order of events, gathering about themselves the elements of an American civilization that indicated what the future of Oregon would be - what it has long since become." And referring to the early immigrants and Dr. McLoughlin's treatment of them, Dr. Hines said: "What would Dr. McLoughlin do? Would he shut the gates of his fortress? Would he lock the doors of his granaries? Would he deny asylum to the weary, footsore, famishing immigrants? What would he do? We can answer by rehearsing what he did. He forgot, in large measure, that those who lay at his door, sick, weary, poor, and almost ready to die, were not his friends. He fed them and pointed them out the ways in which they could take living root in the soil of that very Oregon which was the covet of England, and had so long been the possession of his own Com- 
pany, albeit they who came were American citizens, and each brought an American flag in his heart if not in his hand.

"To me it seems evident that Dr. McLoughlin clearly saw the inevitable outcome of the struggle between dilatory and procrastinating diplomacy and the steady tramp of the growing army of ox teams that slowly swung down the slopes of the mountains, and, in his humanity, which was wider than his national prejudices, and stronger to control him than his love of gain, gave the final cast of his own act to humanity and peace, rather than to gain and war. I cannot here trace the individual acts that demonstrate this general conclusion, as my aim has been rather to indicate the results and show the conclusions of history than to relate its incidents and chronicle its dates.

"A few years pass on. The great Company, erst and long the rulers of Oregon, disown the acts and reprove the conduct of this man of men. Rising to an even higher altitude of resplendent manhood, with a magnificent scorn he casts down his lofty office, with its salary of \$12,000 a year, at the feet of these knights of the counting-house and ledger, cuts all the bonds that bind him to their service, comes back from the palaces of London to the green woods and soft plains of Oregon, takes his place as an American citizen under the stars and stripes, and thus wins the place of imperishable honor and fame as the true 'Father of Oregon.' There his ablest contemporaries place him. There the great State within whose bounds he died and whose foundations he laid, by the voice of her 
legislature and her chief executive has crowned him. There history, whose verdict I record tonight, and with which my own heart agrees, enshrines him as the greatest of our really great pioneer era."

I have given these opinions because they are those of men who personally knew Dr. McLoughlin. And years after his death, after careful consideration and reflection, they have properly estimated him and, thus remembering, have spoken truly and justly. ${ }^{59}$

Eulogy upon Dr. McLoughlin.

Like many others of the world's great men, Dr. John McLoughlin had many characteristics, apparently conflicting, but making in the aggregate a wonderful and harmonious whole. $\mathrm{He}$ was the autocrat of the early Oregon Country, yet all his feelings and political sympathies were for a republican form of government, and for rule by the people, and for personal liberty; he was a trader, with the training of a trader and of a business man, yet he gave credit, without security, to the early pioneers, because he was a humanitarian; he was quick tempered and impulsive, yet he was courteous and kind, for he was a gentleman; he was stern and severe and a strict disciplinarian, yet he had a sympathy like that of a woman, and a heart as tender and susceptible as that of a little child.

Whatever Dr. John McLoughlin did to or for the Oregon settlers, missionaries and immigrants,

\footnotetext{
${ }^{8 \theta}$ For further opinions of contemporaries of Dr. McLoughlin, see Document S.
} 
he did to every citizen of Oregon, man, woman, and child, for all time, then, now, and to come. In honoring him, we honor ourselves. To fail to honor him and his memory, we would dishonor ourselves. To every true, honest Oregon pioneer, and to the descendants of every Oregon pioneer, has come the pleasing and loving duty of letting the whole world know of Dr. McLoughlin's actions and character, so that memory of him and his humanity shall never perish. The time will come and it should come soon - when a magnificent and stately monument will be erected in Oregon in honor of Dr. John McLoughlin. But it must be a monument of such size and beauty as, in that manner, to show the appreciation of the people of Oregon for him, and of the good and noble deeds of this grand old man.

His name should be enrolled in the Temple of Fame of distinguished Americans. A county in each of the states of Oregon and Washington should be named for him. For prior to March 2, 1853 , what is now the State of Washington, was a part of the Territory of Oregon, and Fort Vancouver, where his noblest deeds were performed, is in the State of Washington. That State would do itself great honor if it should change the name of Thurston County to that of McLoughlin. I am glad that the last Legislative Assembly of Oregon restored the name of Mt. McLoughlin to that sublime, snow-covered mountain in Southern Oregon, sometimes called Mt. Pitt, but, prior to 1838 , named for Dr. John McLoughlin by the early residents of Oregon, and for years called and shown 
on the maps as Mt. McLoughlin. It will forever be known by his name. It would have been appropriate if the Legislative Assembly of Oregon had changed the name of Mount Hood to that of Mount McLoughlin, for, in the days when Dr. John McLoughlin was in charge at Fort Vancouver, it was the custom of the Indians, in what is now called Eastern Oregon and Eastern Washington, to point to Mt. Hood as showing near where was his residence.

Dr. McLoughlin died more than forty-nine years ago. Under the canons of the Roman Catholic Church no one can be canonized until he or she has been dead at least fifty years. If I may do so with propriety, I suggest that, when the fifty years have passed, those in proper authority in that Church cause Dr. John McLoughlin to be canonized, if it is possible to do so. But the people of Oregon, as a people, are not bound by this canon. Already the memory of this grand old man is enshrined in their hearts. To them he is now the patron saint of Oregon, without regard to canon or rules, religion or sect.

Of all the names and titles given to, or bestowed upon Dr. John McLoughlin, the one I like best is "Father of Oregon;" for he was, and is truly, the Father of Oregon. And it enables every old, true Oregon pioneer, and every son and daughter of every Oregon pioneer, and his and her descendants, to the remotest generations, to speak of Dr. John McLoughlin with affection and love, with respect and veneration as "Our Father." In the past the fervent prayers of these grateful pioneers 
were made in his praise and that his tribulations might end and persecutions of him might cease. Their tears consecrated his martyrdom and his memory. Today the hearts of the survivors and of the descendants of these pioneers quicken at thoughts of what he was and what he did; and their eyes moisten in recalling what he suffered and what he endured in the making of Oregon.

Of all the men whose lives and deeds are essential parts of the history of the Oregon Country, Dr. John McLoughlin stands supremely first - there is no second. In contemplating him all others sink into comparative insignificance. You may search the whole world, and all its histories from the beginning of civilization to today, and you will find no nobler, no grander man than Dr. John McLoughlin. His life and character illustrate the kinship of man to God. He was God-like in his great fatherhood, in his great strength, in his great power, and in the exercise of his strength and of his power; he was Christ-like in his gentleness, in his tenderness, in his loving-kindness, and in his humanity. 


\section{ILLUSTRATIVE DOCUMENTS}

REFERRED TO IN

THE TEXT 



\section{DOCUMENT A}

Article 3 of the Convention between the United

States of America and Great Britain, signed at London, October 20, I8I8.

"It is agreed that any country that may be claimed by either party on the north-west coast of America, westward of the Stony Mountains, shall, together with its harbors, bays, and creeks, and the navigation of all rivers within the same, be free and open for the term of ten years from the date of the signature of the present convention, to the vessels, citizens, and subjects, of the two powers; it being well understood that this agreement is not to be construed to the prejudice of any claim which either of the two high contracting parties may have to any part of the said country, nor shall it be taken to affect the claims of any other power or state to any part of the said country; the only object of the high contracting parties, in that respect, being to prevent disputes and differences among themselves."

\section{DOCUMENT B}

Convention between the United States of America and Great Britain, signed at London, August $6, I 827$.

"Article I. All the provisions of the third ar- 
ticle of the convention concluded between the United States of America and his majesty the king of the United Kingdom of Great Britain and Ireland, on the 20th of October, I818, shall be, and they are hereby, further indefinitely extended and continued in force, in the same manner as if all the provisions of the said article were herein specifically recited.

"Art. 2. It shall be competent, however, to either of the contracting parties, in case either should think fit, at any time after the 2oth of October, I828, on giving due notice of twelve months to the other contracting party, to annul and abrogate this convention; and it shall, in such case, be accordingly entirely annulled and abrogated, after the expiration of the said term of notice.

"Art. 3. Nothing contained in this convention, or in the third article of the convention of the 2oth October, 1818, hereby continued in force, shall be construed to impair, or in any manner affect, the claims which either of the contracting parties may have to any part of the country westward of the Stony or Rocky Mountains."

\section{DOCUMENT C}

Statement concerning merger of Hudson's Bay Company and North-West Company; and grant to Hudson's Bay Company of I82I and 1838 to trade in the Oregon Country.

A great enmity arose between the Hudson's Bay 
Company and the North-West Company. In I 8 I 5 a regular war broke out between the two companies, which was, for some time after, openly carried on. In I82 I a compromise was effected, by which the North-West Company became united with, or rather merged, in the Hudson's Bay Company. In connection with this merger the British Parliament July 2, I $82 \mathrm{I}$, passed an act entitled, "An act for regulating the fur trade and establishing a criminal and civil jurisdiction in certain parts of North America," containing every provision required to give stability to the Hudson's Bay Company, and efficiency to its operation. Under this act of Parliament, the King was authorized to make grants or give licenses for the exclusive privilege of trading with the Indians in all such parts of North America, not being parts of the territories previously granted to the Hudson's Bay Company, or of any of His Majesty's provinces in North America, or of any territories belonging to the United States of America; "provided, however, that no such grant or license shall be given for a longer period than twenty-one years; that no grant or license for exclusive trade, in the part of America west of the Rocky mountains, which, by the convention of I 818 with the United States, remained free and open to the subjects or citizens of both nations, shall be used to the prejudice or exclusion of citizens of the United States engaged in such trade; and that no British subject shall trade in those territories west of the Rocky mountains without such license or grant."

December 2I, I82I, the King of England 
granted a license for twenty-one years, to the Hudson's Bay Company and to W. McGillivray, S. McGillivray, and E. Ellice (representing the North-West Company) "the exclusive privilege of trading with the Indians, in all such parts of North America, to the northward and westward of the lands and territories belonging to the United States of America, as shall not form part of any of our provinces in North America, or of any lands or territories belonging to the said United States of America, or to any European government, state, or power." Said grant also provided: "And we do hereby declare that nothing in this our grant contained shall be deemed or construed to authorize the said Governor and Company, or W. McGillivray, S. McGillivray, and E. Ellice, or any person in their employ, to claim or exercise any trade with the Indians on the north-west coast of America, to the westward of the Stony Mountains, to the prejudice or exclusion of any citizen of the United States of America, who may be engaged in the said trade: Provided always, that no British subjects other than and except the said Governor and Company, and the said W. McGillivray, S. McGillivray, and E. Ellice, and the persons authorized to carry on exclusive trade by them on grant, shall trade with the Indians within such limits, during the period of this our grant." Under this license, the parties to whom it was granted continued their operations until I824, when the claims of the North-West Company were extinguished by mutual consent; the Hudson's Bay Company then became the sole pos- 
sessor of the privileges conceded, which were enjoyed by that body until the expiration of the grant. Previous to that period, 1838 , a new grant was made to the Company, entitled, "Crown Grant to the Hudson's Bay Company of the Exclusive Trade with the Indians in certain parts of North America, for a term of twenty-one Years, and upon Surrender of a former Grant."

Said grant of 1838 provided: "We do hereby grant and give our license, under the hand and seal of one of our principal secretaries of state, to the said Governor and Company, and their successors, for the exclusive privilege of trading with the Indians in all such parts of North America, to the northward and to the westward of the lands and territories belonging to the United States of America, as shall not form part of any of our provinces in North America, or of any lands or territories belonging to the said United States of America, or to any European government, state, or power, but subject, nevertheless, as hereinafter mentioned: And we do, by these presents, give, grant, and secure, to the said Governor and Company, and their successors, the sole and exclusive privilege, for the full period of twenty-one years from the date of this our grant, of trading with the Indians in all such parts of North America as aforesaid (except as hereinafter mentioned)." Said grant of 1838 also provided: "But we do hereby declare that nothing in this our grant contained shall be deemed or construed to authorize the said Governor and Company, or their successors, or any persons in their employ, to claim or 
exercise any trade with the Indians on the northwest coast of America, to the westward of the Stony Mountains, to the prejudice or exclusion of any of the subjects of any foreign states, who, under or by force of any convention for the time being, between us and such foreign states, respectively, may be entitled to, and shall be engaged in, the said trade." ${ }^{60}$

\section{DOCUMENT D}

Excerpts from Manuscript Journal of Rev. Jason Lee.

The following excerpts are taken from the manuscript journal of Rev. Jason Lee, all of which is in his handwriting. This original journal is now in the possession of the Oregon Historical Society.

"Vancouver, Teus[day], Sept. I6, I834.Arrived at Fort Vancouver 3 o'clock found the Governor and other Gentlemen connected with the Fort on shore waiting our arrival and conducted us to the Fort and gave us food which was very acceptable as we had eaten our last for breakfast. We received every attention from these Gentlemen. Our baggage was brought and put into a spacious room without consulting us and the room assigned for our use and we had the pleasure of sleeping again within the walls of a house after a long and fatiguing journey replete with menacies, deprivations, toil and prosperity.

${ }^{80}$ Greenhow's History of Oregon and California, pp. 323-325, 467476 (second edition, 1845); Martin's Hudson Bay Territories and Van- 
"I have been much delighted today in viewing the improvements of the farm, \&c. The dinner was as good and served in as good stile as in any gentleman's house in the east. Fine mus $[k] \&$ water melons and apples were set before us which were indeed a luxury after the dry living we have had for some time. After dinner took a turn in the Garden and was astonished to find it in such a high state of cultivation. The orchard is young but the quantity of the fruit is so great that many of the branches would break if they were not prevented by props.

"Dr. McLoughlin the Governor of the Fort seems pleased that Missionaries have come to the country and freely offers us any assistance that it is in his power to render. It is his decided opinion that we should commence somewhere in this vicinity. O Lord do thou direct us in the choice of a location. This evening received the joyful inteligence that Capt. Wyeth's Brig was in sight. It is a matter of joy because the last we heard it was on a sand-bar some $70 \mathrm{mi}$. below and we found we should be obliged to go down for our goods. Is not the hand of Providence in all this? Would to God that I could praise him as I ought for his gracious dealings with us. It is now past II o'clock and I must commend myself to divine care and retire.

"Friday Sep. I9, I834.- Daniel and myself are now on the bank of the Willamette River a little distance from Mr. McKay's place. Wednesday

couver's Island, pp. I51-165; Bryce's The Remarkable History of the Hudson's Bay Company, Chapters XXIV to XXIX. 
expected that the Brig would come up to Vancouver and we should receive our goods there but the want of wind prevented her coming up. Went on board just at night and ascertained that we could not get them until the cargo was taken out. Slept on board and walked to the Fort $3 \mathrm{mi}$. in the morning and commenced preparations for a trip up the Willamette. Dr. Mc. made all the necessary preparations of men, boat, food, \&c. and we were off about 4 o'clock. Camped upon the sand. Started early this morning and came to the mouth of the W. [Willamette] and found the Brig there. Took breakfast on board. Waited while Capt's Lambert, Wyeth \& Thing explored the vicinity in search of a place to suit their business but the $[y]$ could find none to please them. Left them with the expectation that they will unload some of their goods and arms at or near the place where they now are. Arrived 1/2 past I o'clock."

After an exploring trip up the Willamette River, which is described in his journal, Jason Lee sets forth: "Sat. 27 [Sept.]. Arrived at the Fort g. h. found our brethern well.

"After mature deliberation on the subject of our location and earnest prayer for divine direction I have nearly concluded to go to the W. [Willamette]."

"Sun. 28 Sep. I834. - A. M. Assayed to preach to a mixed congregation English French scotch Irish Indians Americans Half Breeds Japanese \&c. some of whom did not understand 5 words of english. Found it extremely difficult to collect my thoughts or find language to express them but am 
thankful that I have been permited to plead the cause of God on this side the Ry. Mountains where the banners of Christ were never before unfurled. Great God grant that it may not be in vain but may some fruit appear even from this feeble attempt to labour for Thee.

"Evening Preached again but with as little liberty as in the morning, but still I find it is good to worship God in the public congregation."

"Mon. Sep. 29, 1834. This morning began to make preparations in good earnest for our departure to the W. [Willamette] and after dinner embarked in one of the Company's boats kindly maned for us by Dr. McLoughlin who has treated us with the utmost politeness, attention and liberality. The Gentlemen of the Fort accompanied us to the boat and most heartily wished us great success in our enterprise. Arrived at the lower mouth of the W. where Capt. Wyeth's Brig is late in the evening."

"Wednes[day] Sep. 31, I834. This morning put Br's D. Lee \& Edwards on shore to go to Mr. MKay's place to get horses and we pursued our course up the river. Met Capt. Wyeth on his return from his farm and shall not see him again til summer. Camped on a small prairie about $9 \mathrm{mi}$. from the Falls and found here the men which the Dr. had sent with the cattle he has lent us 8 oxen 8 cows \& 8 calves."

After November 9, 1834 , there is no entry in this journal until August 18, 1837, where there is an entry by Jason Lee, saying that he has not kept up his journal. There is no further entry until 
July 28, I838, which was written at North Fork, Platte River, when he was on his first trip to the eastern states. He says in his journal that on February 16,1838 : "The 16 Feb. [1838] I set out for Umpqua, and after 23 days, of toil and hard-ship reached home in safety, and after a few days rest found myself rather better for the trip. This was encouraging, considering the difficulties encountered such as being drenched in rain many times, fording creeks high enough to wet our feet, sleeping in wet clothes, and blankets, very bad roads and sometimes hard marching, \&c. The subject of the necessity of some one of the Mission Family visiting the $\mathrm{U}$. S. had been agitated during the winter, and it was at length decided by a majority that it was expedient for me to go. Previous to leaving for Umpqua, I had written Dr. McLoughlin, requesting a passage, in the companies Boats, with himself by the Hudson Bay route. This I greatly preferred to the route I came, as less fatiguing, less dangerous, better calculated to restore my debilitated system, and much more likely to afford new, interesting and useful information. The answer was near when I left, and was to be brought me by a man, who was to overtake us the second day, but by mistake he sent it to my house, hence I did not get it till my return. The Dr. could not grant my request, and expressed himself 'doubly mortified;' because he could not do me the favour, and should also be deprived of my company." The remainder of the journal is taken up with the account by Jason Lee of his trip East. March 26, 1838 , there is an entry that he left the 
Mission House on the Willamette for the United States. March 28 he arrived at Fort Vancouver. On April 4 he left Fort Vancouver in company with a Hudson's Bay Company's party bound for the Rocky Mountains. The rest of the journal is taken up with his trip Eastward. The last entry in his journal says that on July 17,1838 , he was at Sweet Water River.

\section{DOCUMENT E}

Rev. Jason Lee's visit to the Eastern States in I838; and his Report to the Missionary Board at New York in 1844.

On arriving in the Eastern States in 1838 Rev. Jason Lee seems to have become imbued with the zeal and fervor of an evangelist in regard to christianizing the Oregon Indians, and the necessity of more missionaries in Oregon. Rev. Dr. Hines in his Missionary History of the Pacific Northwest, p. 194, says: "Mr. Lee devoted the winter of 1838 and the summer of 1839 to traveling and delivering missionary addresses in the cities and larger towns of the Atlantic states. He was accompanied in his journeys by the two Indian boys, Wm. Brooks and Thomas Adams, brought with him from his missionary school in Oregon, whose presence and intelligent speeches added greatly to the popular enthusiasm. Lee's appeals were irresistible. The fire of his zeal caught on the altars of the church everywhere. Oregon and the Oregon Mission fired the heart of the church as no 
mission ever did before. The age of apostolic fervor seemed to have returned, and Lee was in the eye of the church like the great Apostle to the Gentiles building on no other man's foundation. The thought of distant wilds, where uncounted red men waited and longed for deliverance from the darkness of heathenism that had wrapped all their race for all these ages became an ever present vision to the church of the United States." In this History, p. 195, Dr. Hines also says: "Poverty donated its little; wealth gave its 'gold, frankincense, and myrrh.' . . . The culture of Boston responded; the pride of New York cast its jewels into the treasury. The staid sobriety of Philadelphia wept and shouted and gave. Baltimore outdid the renown of her ancient missionary fame. Lee, erst the lumberman of Canada, later the pioneer missionary, who had dipped his banner in the spray of the Pacific was the hero of the hour." But in his oral report to the Missionary Board in July, I 844 , after quoting the following from the letter of a complaining fellow missionary who went to Oregon on the Lausanne: "And indeed they [the Indians] have no life or energy and are a melancholy, doomed race," Jason Lee said: "I think this is in part true, the Indians on the Willamette will become, as a distinct race, extinct. But I think there will be more Indian blood through amalgamation, running in the veins of white men a hundred years hence, than would have been running in the veins of the Indians, if they had been left to themselves."

In July, 1844 , Rev. Jason Lee made an oral 
report to the Missionary Board in New York. This report was not reduced to writing in full but a brief statement of it was made. A copy of this report, as reduced to writing, corrected by, and in Jason Lee's handwriting, is in the possession of the Oregon Historical Society. The principal serious charges made against Jason Lee, and which caused his summary removal as Superintendent of the Oregon Methodist Mission, had been made secretly, and without notice to him, by members of the Oregon Mission. Lee answered these charges in detail, occasionally with some indignation. These charges against Jason Lee were: using the Mission's funds for speculation for his own use; misuse of Mission funds; and failure to report concerning the property of the Mission.

In this report Jason Lee said of certain Methodist missionaries:

"In one of Bro. Abernethy's letters, he tells you that the Superintendent [Jason Lee] refused to send the report of the state of the property home. There is some error in this. I cannot, I will not, believe that $\mathrm{A}$. intended to charge me with opposing the sending of that report.

"Before I had left Oregon I was aware that Bro. Hines had written to the Board. He had read part of his communication to some persons, who had hinted to me about it. He started from Oregon with me, and I was in hopes we should have met face to face before this Board. He returned, however, from the Sandwich Islands to Oregon.

"Bro. Kone complains of my treatment of him, and professes to know my secret reasons for wish- 
ing to keep all in the field. I never had any secret reasons. . . . Bro. Kone by his injudicious remarks caused great excitement among the laymen, and made much difficulty.

"He considered Dr. Richmond his enemy because he had so declared himself, and sent word to him [Mr. Lee] that he was his antagonist. And he hoped as they had heard his enemy they would hear him.

"Of Bro. Frost I cannot say much. He has made no thorough effort to bring sinners to God. I mean such an effort as would render it probable that these Indians could not be benefited by the Gospel."

In this report Jason Lee also spoke of some other Methodist missionaries who had made charges against him, without giving their names.

As the Board seems to have exonerated Jason Lee from all charges, it must have found that these charges made in Oregon were untrue, or unfounded, or not justified. Exonerating Jason Lee was, in effect, condemning those persons who made the charges, and finding that their charges were false. In this report Rev. Jason Lee also said: "When the Board sent out its last large reinforcement, its object in my view and I believe in theirs was that Methodism should spread throughout Oregon; for what purpose else, I ask, did so large a number of laymen go out? If it was only to form one or two stations, it appears to me that both the Board and myself as their agent must have taken leave of our senses. If my associates had stood firm to their post, and persevered willingly 
in the work consigned them, I have not a doubt but far more favorable accounts would have reached you from that distant country. The plans I assert were well formed and had I been sustained the object would have been accomplished. A great mistake was made in selecting some of those who were sent out. I allude not to the number but the qualifications of certain individuals. I forewarned the Oregon Committee that if the persons who applied for situations were not examined by a proper committee the plan would fail. Such proved to be the case. As proof I aver that we had not reached our first stopping place in South America, before some desired to return to the United States, and even after touching at the S. [Sandwich] Islands before we had reached Oregon one wanted to return and secure the Chaplaincy at the Islands. I have had much to contend with, and I regret that men of more steadfast minds had not been chosen. Such persons do more injury to a distant Mission than they do good, and no one knows the difficulties I have had to pass through."

In this report Rev. Jason Lee said further: "He [Dr. McLoughlin] is a Catholic. Previous to the Priests going there, I was his intimate friend, - his confidant. Such was my influence with the Canadian part of the settlement, that they would have been pleased to give me their church and have no Priest come. Since my return I have not time to instruct their children as we used to do, and the Priests have taken them." 


\section{DOCUMENT F}

Excerpts from Narrative of Commodore Charles Wilkes, U.S. N., published in Philadelphia in I 845 .

Commander Charles Wilkes of the United States Navy, (afterwards Commodore) had charge of an exploring expedition during the years 1838 - 1842 , which came to the Oregon Country in 1841 . His squadron consisted of six vessels, which arrived at Puget Sound in $184 \mathrm{I}$. He left his ships at Puget Sound and came overland to Vancouver in May, 1841. In his narrative of his exploring expedition, published in 1845 , Wilkes says, (vol. IV, p. 327): "He [Dr. McLoughlin] is a tall fine-looking person, of a very robust frame, with a frank, manly, open countenance, and a florid complexion; his hair is perfectly white. He gave us that kind reception we had been led to expect from his well known hospitality. He is of Scotch parentage, but by birth, a Canadian, enthusiastic in disposition, possessing great energy of character, and extremely well suited for the situation he occupies, which requires great talent and industry. $\mathrm{He}$ at once ordered dinner for us, and we soon felt ourselves at home, having comfortable rooms assigned us, and being treated as part of the establishment." And on page 331 he says: "The liberality and freedom from sectarian principles of Dr. M'Loughlin may be estimated from his being thus hospitable to missionaries of so many Protestant denominations, although he is a professed Cath- 
olic, and has a priest of the same faith officiating daily at the chapel. Religious toleration is allowed in its fullest extent. The dining-hall is given up on Sunday to the use of the ritual of the Anglican Church, and Mr. Douglass or a missionary reads the service. . . . Messrs. Griffith and Clarke were entirely disappointed in finding selfsupport here, and had it not been for the kindness of Dr. M'Loughlin, who took them in, they would have suffered much. They were advised to settle themselves on the Faulitz Plains, where I have understood they have since taken land, and succeeded in acquiring quite respectable farms."

June 3, I84I, Wilkes left Vancouver to make an exploring trip up the Willamette Valley. In his account of this trip he says in his narrative, (vol. IV, pp. 343-344): "We reached the falls about noon, where we found the missionary station under the charge of the Rev. Mr. Waller.

There was a petty dispute between Mr. Waller and the [Hudson's Bay] Company, and he complained of them. It seems that the Company refuse to buy any beaver-skins, except from the hunters and trappers; and he accuses them of monopoly in consequence. The Company, on the other hand, say that they have no idea of selling goods out of their own stores, for the purpose of enabling others to enter into competition with them; and that they will spare no expense to keep the trade, as long as they can, in their own hands. This is certainly not unfair. I cannot help feeling it is quite unsuited to the life of a missionary, to be entering into trade of any kind. To embark in traffic must, I think, 
tend to destroy the usefulness of a missionary, or divert his attention from the great cause in which he is engaged. I am very far from attaching any blame on this account to the missionaries, whose avowed object is to teach the arts of civilization, as well as the Word of God, and I have no doubt that they are doing all in their power to promote the latter object; but I am disposed to think, that any complaints against the Hudson Bay Company for endeavouring to keep the trade in their own hands, comes with an ill grace from the members of a Mission who are daily receiving the kindest attentions and hospitality from its officers." In vol. IV, p. 35 I, he says: "The lands of the Methodist Mission are situated on the banks of the Willamette river, on a rich plain adjacent to fine forests of oak and pine. They are about eight miles beyond the Catholic Mission, consequently eighteen miles from Champooing, in a southern direction. . . We had the expectation of getting a sight of the Indians on whom they were inculcating good habits and teaching the word of God; but with the exception of four Indian servants, we saw none since leaving the Catholic Mission. On inquiring, I was informed that they had a school of twenty pupils, some ten miles distant, at the mill; that there were but few adult Indians in the neighborhood; and that their intention and principal hope was to establish a colony, and by their example to induce the white settlers to locate near those over whom they trusted to exercise a moral and religious influence."

In vol. IV, p. 352 , he says: "The next day the 
gentlemen of the Mission proposed a ride to what they term 'the Mill,' distant about nine miles, in a southeast direction. . . . We reached 'the Mill' by noon, which consists of a small grist and saw mill on the borders of an extensive prairie. They are both under the same roof, and are worked by a horizontal wheel. . . From the number of persons about the premises, this little spot had the air and stir of a new secular settlement; and I understood that it is intended to be the permanent location of the Mission, being considered more healthy than the bank of the Willamette. The missionaries, as they told me, have made individual selections of lands to the amount of one thousand acres each, in prospect of the whole country falling under our laws."

On page 355 of the same volume he says: "I am aware that the missionaries come out to this country to colonize, and with the Christian religion as their guide and law, to give the necessary instruction, and hold out inducements to the Indians to quit their wandering habits, settle, and become cultivators of the soil. This object has not been yet attained in any degree, as was admitted by the missionaries themselves; and how it is to be effected without having constantly around them large numbers, and without exertions and strenuous efforts, I am at a loss to conceive. I cannot but believe, that the same labour and money which have been expended here, would have been much more appropriately and usefully spent among the tribes about the Straits of Juan de Fuca, who are numerous, and fit objects for instruction." And on 
page 356 Commander Wilkes says: "Three years since, O'Neill came to the valley with only a shirt to his back, as he expressed it; he began by working part of this farm, and obtained the loan of catthe and other articles from Dr. M'Loughlin, all of which he has, from the natural increase of his stock and out of his crops, since repaid. He has bought the farm, has two hundred head of stock, horses to ride on, and a good suit of clothes, all earned by his own industry; and he says it is only necessary for him to work one month in the year to make a living; the rest of the time he may amuse himself. He spoke in the highest terms of $\mathrm{Dr}$. M'Loughlin, and the generous aid he had afforded him in the beginning."

The Peacock, one of the vessels of the squadron, was wrecked July $18,184 \mathrm{I}$, on a spit near Cape Disappointment on the north side of the entrance to the Columbia River, ever since known as Peacock Spit. The vessel was a total loss. Commander Wilkes says that the crew of the Peacock were supplied with clothing through the kindness of Dr. McLoughlin and the officers of the Hudson's Bay Company. Wilkes further says that "every facility has been at all times extended [by Dr. McLoughlin] to newcomers and settlers; it is sufficient that they are of good character, and the use of cattle, horses, farming utensils, and supplies, is invariably extended to facilitate their operations, until such time as they are able to provide for themselves." At the time of the wreck of the Peacock, there was lying at Astoria the American brig Thomas H. Perkins. She was under charter 
to the Hudson's Bay Company. Dr. McLoughlin readily agreed to surrender the charter party for a small consideration, if the goods he had on board were delivered at Fort Vancouver. This Wilkes agreed to and purchased the brig. He changed her name to the "Oregon." In August, I 841, the Oregon was taken to Fort Vancouver to be repaired and outfitted. In the meantime Wilkes proceeded slowly up the Columbia River in the naval gun-brig Porpoise, of two hundred and thirty tons, making a survey of the river. The Porpoise arrived at Fort Vancouver August 28, and remained there until September 14, I84I. The expedition was treated with kindness and courtesy while at Fort Vancouver.

Fresh beef seems to have been scarce even in I84I. Wilkes in his narrative says that on September 27, I84I, the Porpoise was at Puget's Island, near Cathlamet. Here he was joined by Michel La Framboise, in the employ of the Hudson's Bay Company, "who brought a supply of fresh beef for the crew, which they were much in need of." On leaving the Columbia River, Wilkes addressed a letter from Baker's Bay, dated October 5, I84I, to Dr. McLoughlin and James Douglas as Chief Factors of the Hudson's Bay Company, giving thanks "for the important aid and facilities which you have afforded the Expedition on all occasions, for carrying out the object of our visit to this part of the world;" and saying, "be assured it will prove a very pleasing part of my duty to make a due representation of it to my government." And also saying: "Your personal kind- 
ness and friendly attention to myself and officers, from our first arrival, and also to Captain Hudson and his officers after the wreck of the Peacock, have laid me under many obligations which I trust it may be at some future day in our power to return." (Vol. v, p. 147).

\section{DOCUMENT G}

Letter from Henry Brallier to Frederick V. Holman of October 27, 1905.

Since I delivered my address on McLoughlin Day, I have received the following letter. The persons referred to are probably a small party, who came to Oregon prior to I840. There were several small parties of immigrants to Oregon, who came prior to 1842 . Robert Shortess came overland in 1839 and 1840 to Oregon with one of these parties.

"Mr. Frederick V. Holman,

"Seaside, Oct. 27, 1905."

"Portland, Oregon.

"Dear Sir: In the Sunday Oregonian of the $15^{\text {th }}$ of this month I see an interesting account of Dr. McLoughlin, but one act of his that showed his human kindness, I have never seen in print. This a man by the name of Marechell told me. He was an old Hudson's Bay man who died here in his eighty-sixth year. He could not recollect the exact year, but it was a year or two after Wyeth came, the emigrants got lost in the head waters of Snake River, and would have all perished but the Indians brought word from one tribe to another 
about them being there, until it reached Fort Vancouver. When the Doctor heard it, he rushed around like one wild and called, 'Where is Marechell! Where is La Framboise.' He started them with a lot of provisions in their canoes, with some others to help to the Cascades, there to pack them over, then get them in their canoes again, take them to The Dalles, and there they got ponies to pack them on their journey to the emigrants, a weary trip. And after some two weeks' trip, they found the emigrants encamped in a small valley, there still to live a short time and then starve to death. He said if ever it tried a man's soul, then it did his. The poor women came running to him, fell on their knees, hugging them and crying. Men crying and blessing them and the Doctor for sending them. I often think if there is an upper seat around the throne of God, that the Doctor and some of those men that were so kind to others, are there now.

"This man Marechell came with the Hudson's Bay Company, when he was 12 years of age, with his father. As near as he could tell he was about 22 years of age when he took the trip to find the emigrants.

"I came to the Coast in early ' 52 ; to Oregon in '58; to Astoria in '63, and to Seaside soon after. So I knew Marechell well, and did see La Framboise a number of times. So what Marechell told me I believe is true.

"Beg pardon if this intrudes on your time and patience.

$$
\begin{aligned}
& \text { "Respectfully, } \\
& \text { "Henry BraLlier, } \\
& \text { "Seaside, Oregon." }
\end{aligned}
$$




\section{DOCUMENT H}

Shortess Petition; excerpts from Gray's "History of Oregon" relating to Shortess Petition; and excerpt from speech of Samuel $R$. Thurston in Congress, December 26, I850, as to author of Shortess Petition.

"To the honorable the Senate and House of Representatives of the United States of America in Congress assembled:

"We, the undersigned, settlers south of the Columbia river, beg leave respectfully to represent to your honorable body:

"As has been before represented to your honorable body, we consider ourselves citizens of the United States, and acknowledge the right of the United States to extend its jurisdiction over us; and the object of the present memorial is to ask that the protection of the United States Government may be extended to us as soon as possible. Hitherto, our numbers have been small, and the few difficulties that arose in the settlement were speedily and satisfactorily settled. But as our settlement increases in numbers, so our difficulties increase in number and importance; and unless we can have laws to govern us that will be respected and obeyed, our situation will be a deplorable one. Where the highest court of appeal is the rifle, safety in life and property cannot be depended on. "The state of the country, its climate, resources, soil, productions, \&c., has already been laid before 
your honorable body, in Captain Wyeth's memoir and in former memorials from the inhabitants of this place.

"Laws are made to protect the weak against the mighty; and we feel the necessity of them in the steps that are constantly taken by the honorable Hudson Bay Company, in their opposition to the improvement and enterprise of American citizens. You have been apprized already of their opposition to Captains Wyeth, Bonneville, and others; and we find that the same spirit dwells with them at the present day. Some years ago, when the Hudson Bay Company owned all the cattle in Oregon, they would not sell on any conditions; but they would lend their cows to the settler - he returning to the company the cows loaned, with all the increase; and, in case of the death of a cow, he then had the privilege of paying for it. But, after the settlers, at great risk and expense, went to California, and purchased cattle for themselves, and there was a fair prospect of the settlement being supplied, then the Hudson Bay Company were willing to sell, and at lower rates than the settler could sell.

"In the year I 841 , feeling the necessity of having mills erected that could supply the settlement with flour and lumber, a number of the inhabitants formed themselves into a joint stock company, for the purpose of supplying the growing wants of the community. [Many of the farmers were obliged to leave their farms on the Willamette, and go six miles above Vancouver, on the Columbia River-making the whole distance 
about sixty miles - to get their wheat ground, at a great loss of time and expense.] The company was formed, and proceeded to select a site. They selected an island at the falls of the Willamette, and concluded to commence their operations. After commencing, they are informed by Dr. McLoughlin, who is at the head of the Hudson Bay Company's affairs west of the Rocky Mountains, that the island is his, and that he (although a chief factor of the Hudson Bay Company) claims all the lands at the east side of the Willamette, embracing the falls down to the Klakamus river, a distance of about tivo miles. He had no idea, we presume, that the company would succeed. However, he erected a shed on the island, after the stuff was on the island to build a house, and then gave them permission to build under certain restrictions. They took the paper he wrote them, containing his conditions; but did not obligate themselves to comply with the conditions, as they did not think his claim just or reasonable.

"Many projects had been started by the inhabitants, but, for want of means and encouragement, failed. This fate was predicted for the Milling Company. But, after much labor and difficulty, they succeeded in getting a saw mill erected, and ready to run; and entered into a contract to have a grist mill erected forthwith. And now, as they have succeeded, where is the Hudson Bay Company? Dr. McLoughlin employs hands to get out a frame for a saw mill, and erect it at the Willamette falls; and we find, as soon as the frame is up, the gearing which has been made at Vancouver is 
brought up in boats; and that which caused a feeble company of American citizens months of toil and embarrassment is accomplished by the chief factor of the Hudson Bay Company in a few weeks; (he has men and means); and it is said by him, that in two weeks his mill will be sawing. And what will be the consequences? Why, if the Milling Company sell for $\$ 15$ per thousand, he can sell for \$12; if they reduce the price to $\$ 10$, he can come to $\$ 8$, or $\$ 5$, or $\$ 2$ per thousand. He says he will have a grist mill started as soon as he gets the saw mill in operation.

"All the wheat raised in Oregon they are anxious to get, as they ship it to the Russians on the Northwest coast. In the first place, they measured the wheat in a half bushel, called by them imperial measure, much larger than the standard measure of the United States; this not answering, they next proceeded to kick the half bushel with the foot, to settle the wheat; then they brought up a measure larger than the former one; and now they fill this measure, then strike it three times with a stout club, and then fill it up, and call it fair measure. Against such proceedings we need law that will be respected and obeyed.

"About twelve or fourteen years ago the Hudson Bay Company blasted a canal a few feet to conduct water to a mill they were going to build, the timber for which is now lying at the falls rotting. They, however, abandoned the thing altogether, and built their mills on the Columbia, about six miles above Fort Vancouver, on the north side of the river. 
"In the year 1838 , agreeably to orders left by Mr. Slacum, a house was erected at the falls, to secure the claim for him.

"In 1840, the Methodist mission erected buildings at the falls, and stationed two families there, and made a claim to sufficient land for their buildings, not interfering with any others who might wish to build. A short time previous to this, Dr. McLoughlin had a storehouse erected for the company, not occupied, however, further than to store wheat and other articles in, and as a trading house during the salmon season.

"After this, in I84I, a shantee was erected, and a man kept at the falls, whose business it was to trade with the Indians for furs and salmon, and look out for the Doctor's claim, he said, and to forbid persons building at the falls, as some had built, and others were about building. This man was, and still is, a servant of the Hudson Bay Company.

"During the years 1841 and 1842 , several families settled at the falls, when Dr. McLoughlin, who still resides at Fort Vancouver, comes on the ground, and says the land is his, and any person building without his permission is held as a trespasser. Without reference to any person's right or claim, he employs a surveyor to lay out the plat; and as a bill was before the Senate of the United States to grant to every white male inhabitant a mile square, he has a mile run out to suit his views, and lays out a town plat at the falls, and calls it Oregon City. And although some, for peace sake, asked him for the lots they had already in posses- 
sion, and which he appeared very willing to grant, the Doctor now felt himself secure, and posted up the annexed paper, (marked A) which is the original; and all who had lots were required to pay Mr. Hastings five dollars for a deed of land which they knew very well the grantor did not own, and which we hope he never will own, but that Congress will pass a special act granting to each man his lot and improvements. Those that applied received (if they had a house on the lot) a deed, a copy of which is annexed, (marked B); if they had no house, a bond was given for five dollars, a copy of which is annexed, (marked C). To those that applied and paid their five dollars, all was right with the Doctor; while those who considered his title to the land not good, and that therefore he had no right to direct who should build and who should not, had their lots sold to others. In one case the purchaser came to the original claimant, and ordered him to stop digging the ground which he was preparing for a garden, and commanded him to remove his fences, as he had Dr. McLoughlin's bond in his pocket for the lots; and if he did not move his fence he would, and take forcible possession. Those who desired to have no difficulty, and did not apply for a deed, have lost their lots, the Doctor's promise, and all. And Mr. Hastings (the Doctor's agent) is now offering for sale the lots on which part of the mission buildings stand; and if he succeeds in finding a purchaser, they must either contend or lose their buildings.

"Dr. McLoughlin had held claims in other places south of the Columbia river - at the Tua- 
latin plains and Klakamus plains he had huts erected, to prevent others from building; and such is the power of Dr. McLoughlin, that many persons are actually afraid to make their situation known, thinking, if he hears of it, he will stop their supplies. Letters were received here from Messrs. Ladd \& Co., of the Sandwich Islands, in answer to a letter written by the late Mr. Ewing Young, for a few supplies, that orders were received, forbidding the company's vessels carrying any goods for the settlers of Oregon. Every means will be made use of by them to break down everything that will draw trade to this country, or enable persons to get goods at any other place than their store.

"One other item, and we are done. When any United States Government officers of distinction arrive, Vancouver is thrown open, and every facility afforded them. They were even more condescending to the settlers during the time the exploring squadron was in the Columbia; nothing was left undone to give the officers a high opinion of the honorable Hudson Bay Company. Our Indian agent is entirely dependent on them for supplies and funds to carry on his operations.

"And now your memorialists pray your honorable body, that immediate action of Congress be taken in regard to this country, and good and wholesome laws be enacted for our Territory, as may, in your wisdom, be thought best for the good of the American citizens residing here.

"And your memorialists will ever pray.

"Robert Shortess, A. E. Wilson, William C. 
Remick, Jeffrey Brown, E. N. Coombs, Reuben Lewis, George Davis, V. Bennet, J. Rekener, T. J. Hubbard, James A. O'Neil, Jer. Horregon, William McKarty, Charles Compo, John Howard, his + mark, R. Williams, G. Brown, John Turner, Theodore Pancott, A. F. Waller, John Hofstatter, G. W. Bellamy, William Brown, A. Beers, J. L. Parrish, William H. Gray, A. D. Smith, J. C. Bridges, Aaron Cook, A. Copeland, S. W. Moss, Gustavus Hines, George W. LeBreton, J. R. Robb, J. L. Morrison, M. Crawford, John Anderson, James M. Bates, L. H. Judson, Joel Turnham, Richard H. Ekin, H. Campbell, James Force, W. H. Willson, Felix Hathaway, J. Lawson, Thomas J. Shadden, Joseph Gibbs, his + mark, S. Lewis, Jr., Charles Roy, William Brum, S. Davis, Joseph Yatten, Daniel Girtman, C. T. Arrendrill, A. Tonner, David Carter, J. J. Campbell, W. Johnson, John Edmunds, W. Hauxhurst, W. A. Pfeiffer, J. Holman, H. B. Brewer, William C. Sutton.

"Willamette, Oregon Territory, March 25, I 843 .'

NOTICE

"Notice is hereby given to all whom it may concern, that those who have obtained grants of lots in Oregon City will be expected to call upon L. W. Hastings, my authorized agent at Oregon City, and obtain a bond for a deed or deeds, as the case may be. Those who hold claims to any lot, and 
who comply with the above requisite on or before the first day of February next, will be entitled to their lot or lots; otherwise, the lots upon which they hold a claim will thereafter be subject to any disposition which the undersigned may think proper to make of them.

"January I 8 , I 843 ."

$$
\text { "John MCLoughlin." }
$$

"Oregon City, March 27, 1843."

"We, the undersigned, do hereby certify that the within [above] notice of John McLoughlin was posted up in the most public place in this town. "R. SHORTESS." "A. E. Wilson."

B.

DEED-JOHN MCLOUGHLIN TO WALTER POMEROY

"Know all men by these presents, that I, John McLoughlin, of Fort Vancouver, in the Territory of Oregon, for and in consideration of the sum of one dollar, to me in hand paid by Walter Pomeroy, of Oregon City, of the Territory aforesaid, the receipt whereof is hereby acknowledged, have this day, and do by these presents, remit, release, and forever quit claim, unto the said Pomeroy, his heirs and assigns, all and singular the following piece, parcel, and lot of land, bounded and described as follows, to wit: commencing at the northeast corner, running thence southerly sixtysix (66) feet to a stake; thence westerly one hundred (IOO) feet to a stake; thence northerly sixty- 
six (66) feet to a stake; thence easterly one hundred ( 100 ) feet to a stake at the place of beginning - being lot number four, $(4$,$) in block number$ three, $(3$,$) in the town of Oregon City, in the Ter-$ ritory of Oregon, which will more fully appear from a reference to the map and plan of said town:

"To have and to hold the same, together with all and singular the privileges and appurtenances thereunto in any wise appertaining or belonging, unto the said Pomeroy, his heirs, executors, administrators, or assigns, forever.

"And I, the said McLoughlin, for myself, do avouch and declare, that I am the true and proper claimant of and to the said premises and lot of land, and that I have in myself full power, good right, and sufficient authority, to remit, release, and quit by claim, to all and singular my right, title, interest, and claim, in and to said lot and premises, in manner and form aforesaid.

"And I, the said McLoughlin, do hereby covenant and agree to warrant and defend the said premises, together with the privileges and appurtenances thereunto appertaining or belonging, to the said Pomeroy, his heirs and assigns, against all lawful claims of all persons whomsoever, the claims of the Government only excepted.

"In testimony whereof, I, the said McLoughlin, have hereunto set my hand and affixed my seal, this the $2 \mathrm{~d}$ day of March, A. D. I 843 .

"John McLoughlin, (L. S.)"

"Per L. W. Hastings, his Agent."

"We, the undersigned, do hereby acknowledge 
that the above is a true and correct copy of the original.

\author{
"R. SHORTESS." \\ "A. E. Wilson."
}

C.

BOND-JOHN MCLOUGHLIN TO ALBERT E. WILSON

"Know all men by these presents, that I, John McLoughlin, of Fort Vancouver, in the Territory of Oregon, am held and firmly bound unto Albert E. Wilson, of Oregon City, in the Territory aforesaid, in the full sum of five hundred, federal money; for the punctual payment of which, well and truly to be made, I bind myself, my heirs, executors, or administrators, firmly by these presents.

"In testimony whereof, I have hereunto, below, set my hand and affixed my seal, this the 26th day of December, A. D. I842.

"Now, know ye, that the condition of the above obligation is such, that whereas the said Wilson hath this day, and doth by these presents, purchase of the said McLoughlin all and singular the following pieces, parcels, tracts, and lots of land, namely: lots No. four (4) and five (5) in block No. two, (2), in the town of Oregon City, in the Territory of Oregon, as is more fully shown by the map and plan of the said town; and hath, and by these presents doth, agree to build upon and improve each of the said lots within the term of one year from the date of these presents. In considera- 
tion of which, the said McLoughlin hath and doth by these presents covenant and agree to make to the said Wilson a good and sufficient quit claim deed for and to all and singular the above-mentioned pieces, parcels, tracts, and lots of land, whenever he, the said Wilson, shall have complied with the above conditions on his part. Now, if the said McLoughlin shall well and truly make, or cause to be made, the said deed to the said Wilson, upon the said Wilson's complying on his part with the above condition, then and in such case the within obligation shall become entirely void and of no effect; otherwise, to be and remain of full force and virtue.

"John McLoughlin, (L. S.)" "Per L. W. Hastings, his Agent."

"We, the undersigned, do hereby acknowledge the above to be a true and correct copy of the original.

"R. SHORTESS."

"A. E. WILSON." ${ }^{61}$,

W. H. Gray was one of the signers of the Shortess petition. In his History of Oregon, pp. 296, 297 , he says, in relation to certain persons who did not sign the Shortess petition:

"Mr. George Abernethy declined to sign this

${ }^{01}$ This copy of the Shortess petition is made from the United States Senate Document as printed by its order of February 7,1844 . It is Senate Document 105, 28th Congress, Ist Session. One copy of this original Senate Document is in the possession of Milton W. Smith, Esq., of Portland, Oregon. By his courtesy the foregoing copy was made from said Senate Document. The purported copy of the Shortess petition in Gray's History of Oregon and in Brown's Political History of Oregon are not true copies. 
petition through fear of injuring the Methodist Mission in its secular or business relations with the Hudson's Bay Company.

"Hugh Burns would not sign it because he did not wish Congress to be asked to confirm his title to lots and improvements.

"Jason Lee, though he thought it right to petition Congress for protection, yet on account of his position as Superintendent of the Methodist Mission, and the influence of the [Hudson's Bay] Company against them should he sign it, thought it best not to give his name.

"Dr. I. L. Babcock refused, because, by signing he would lose his influence with the [Hudson's Bay] company.

"Walter Pomeroy, ditto.

"Dr. Bailey did not wish any protection from the Congress of the United States.

"Rev. H. K. W. Perkins was ashamed of the petition. 'What does Congress care about measuring wheat? or a contest between two milling companies?'

"George Gay did not care anything about it. Congress might do as it pleased; he did not want its protection.

"The people in Tualatin Plains did not have an opportunity to sign or refuse for want of time to circulate it in that section. The bearer of it, William C. Sutton, was on his way to the States across the Rocky Mountains."

Thurston in his speech in Congress December 26 , I 850 , said, as to the author of the Shortess petition: "I know the gentleman who wrote the orig- 
inal, whom to know is to respect, to listen to to believe. He is a gentleman of the highest standing in Oregon, of some twelve or fourteen years residence and who would be universally believed on any subject on which he would presume to speak." ${ }^{62}$ Thurston certainly did not refer to Shortess. The latter, while a man of ability and some education, was of an ascetic disposition, intense in his dislikes and given to sarcasm. He was not a popular man.

That the Shortess petition was written by George Abernethy is shown in a foot-note on page 207 of volume I, History of Oregon, Bancroft's Works, where it is said that "such is the statement of Shortess made to Elwood Evans by letter in I 867," quoting from a manuscript history of Oregon written by Evans for Bancroft. Subsequently Evans wrote an elaborate history of Oregon and Washington, entitled "History of the Pacific Northwest," which was published in 1889. On page 243 of volume I of this history Evans says that September I, 1867, Shortess wrote an autograph letter to Evans that Shortess originally drew up notes or a summary of the subjects he intended to embrace in the petition. That Shortess requested Abernethy "to write it in proper form, which he did, but refused to sign it or allow it to be circulated in his handwriting, fearing it might injure the mission. I had it copied by A. E. Wilson. It was circulated and, through his assistance, sent to Washington."

Shortess arrived in the Willamette Valley in ${ }^{62}$ See Document $\mathrm{N}$. 
April, i840. He afterwards took up a land claim near Upper Astoria. He sold his claim and became a recluse. He died in 1877 . Some time after he signed the Shortess petition he appears to have changed his opinions of the Hudson's Bay Company, and especially of the Methodist missionaries. He wrote a document about his trip to Oregon which he gave to Mr. William Chance. The latter gave this document to the Oregon Pioneer Association. It is published in full in the Transactions of the Oregon Pioneer Association for 1896, pp. 92-I07. It is a very interesting document. In it he refers to the Methodist missionaries in terms which, at least, are not complimentary.

\section{DOCUMENT I}

Ricord's Proclamation; letters of $A$. Lawrence Lovejoy and Rev. A. F. Waller of March 20, I844; Ricord's Caveat; invalidity of Waller's claim to Dr. McLoughlin's land; and excerpts from letters of Rev. Jason Lee to Rev. A. F. Waller and Rev. Gustavus Hines, written in I 844 .

The following is a copy of a proclamation dated December 20, I 843 , and issued by John Ricord, as attorney for Rev. Alvin F. Waller. The original of this document in the handwriting of $\mathrm{Ri}$ cord, and signed by him, pasted on cloth, is in the possession of the Oregon Historical Society. Said original was publicly posted at Oregon City by Waller after Ricord left for the Hawaiian Is- 
lands. It shows weather stains, but is perfectly legible.

"To The People of Oregon.

"Fellow Citizens,

"Having been Retained professionally to establish the Claim of Mr. Alvin F. Waller to the Tract of Land on the East Bank of the Wallammette River, sometimes called the Wallammette Falls Settlement and sometimes Oregon City, I consider it a duty to my Client and the public, to state briefly and concisely the several circumstances of his case, as they really exist, in order that his motives may not be impugned and his intentions misunderstood and misrepresented.

"The public are already aware that my client commenced the Occupancy of his Farm, in the spring of A. D. 1840 , when no one resided at the falls; and that, in the course of that Summer, he built his Home, moved his family into it, and cleared and fenced a good portion of the Land, from which, in the ensuing years A. D. $1841 \&$ I 842 he raised successive crops of corn, Potatoes and other vegetables usually cultivated by Farmers. That he remained thus occupying undisturbed, until the month of December A. D. 1842, about two years and six months, when Doctor McLoughlin caused his Farm to be surveyed, for the purpose of selling it in subdivisions to American Citizens. It has since been currently reported and quite generally believed, that my client had renounced his right in favor of Doctor McLoughlin. This I am authorized to contradict, having perused the letter written by Mr. Waller, which 
not only contains no renunciation, but on the contrary, is replete with modest and firm assertions of his rights in the premises: offering at the same time to relinquish his claim, if the Doctor would comply with certain very reasonable and just conditions. Upon this offer, the parties had come to no final conclusion, until my arrival in the Colony, when Doctor McLoughlin attempted to employ me to establish his claim, disregarding the rights of all other persons - which, I declined doing. Mr. Waller thereupon engaged me to submit the conditions a second time to the Doctor, for his acceptance or rejection; which I did in the following words:

"Ist. That your preemptive line be so run as to exclude the Island upon which a private Company of Citizens have already erected a Grist Mill - conceding to them so much water as may be necessary for the use of said Mill.

" 2 d. That Mr. Waller be secured in the ultimate Title to the two city Lots now in his possession and other lots not exceeding in superficial area five Acres, to be chosen by him from among the unsold lots of your present Survey.

" 3 d. That the Rev. Mr. Lee on behalf of the Methodist Episcopal Mission, be in like manner secured in the lots claimed for the use of said Mission. They consist of Church and Parsonage lots and are well known to the public.

"I received a letter from Dr. McLoughlin dated Ioth Novr. I843, in answer to mine, in which he declines complying with the above Conditions, and thus puts an end to the offer of my Client to relinquish his right of Preemption. Under these 
circumstances Mr. Waller has now applied to the Supreme Court of the United States, which, under the Constitution has original jurisdiction of "all cases in Law \& Equity, arising under Treaties," to grant him a Commission for perpetuating the testimony of the facts in his case, de bene esse, in order that, whenever Congress shall hereafter see fit to prescribe by law the conditions and Considerations, he may be enabled to demand of the United States, a Patent; also praying the Court to grant him such other relief in the premises as may be consonant with Equity and good conscience.

"The Legality of Mr. Waller's claim rests upon the following Grounds:-

"Ist. He was a citizen of the United States of full age and possessed of a family when he first came to reside on the premises. 2d. He built a House upon them and moved his family into it; thus becoming in Fact and in Law a Householder on the land. $3 \mathrm{~d}$. He cleared, fenced and cultivated a portion of it during two years and six months, before he was disturbed in his actual pos-

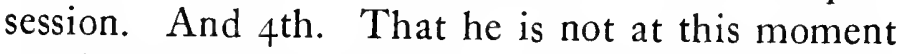
continuing the cultivation of his Farm, is not his fault since it was wrested from him.

"The Illegality of Doctor McLoughlin's Claim rests upon the following Grounds:-

"Ist. He is a British Subject, owing allegiance to a Foreign Power, and has so continued to be ever since the Spring of A. D. I840. For this reason alone he could not acquire preemption to lands in the United States.

" 2 d. He is the Chief Officer of a Foreign Cor- 
porate Monopoly. For this reason alone he could not acquire preemption to lands in the United States.

" 3 d. He does not now and never did reside on the land in question, but on the contrary, he resides and has always continued to reside on the North side of the Columbia River, the Section of country actually in dispute between the two Governments, about Twenty miles from the land claimed by Mr. Waller, and there he is obliged to remain, so long as he continues to be Chief Factor.

"4th. He is not in fact the Claimant. The Hudson's Bay Company, a Foreign Corporation, is in fact the Claimant while Doctor McLoughlin only lends his name; well knowing, that a Corporation even though it be an American one, can not acquire a preemption. This is evinced by the employment of men to be his Agents and to sell lots for him, who are at the same time partners in and receiving dividends and Salaries from the Company.

" 5 th. The pretentions of Doctor McLoughlin arose, if at all, two years and six months after the actual Settlement of Mr. Waller; and therefore they are in direct violation of the Treaty of A. D. I 827 : Converting the mutual and joint occupancy into an exclusive occupancy by British subjects.

"6th. The Treaty of joint occupancy [1827] does not and was never intended on the part of the United States, to confer any rights of citizenship upon Foreigners. The Power to confer such 
rights is by the Constitution reserved to Congress. And the right to acquire title by preemption is peculiar to citizens.

"Those fellow citizens are the Facts and some of the Points of Law in my client's case. Upon the same principle contended for by Dr. McLoughlin, any of you may incur the risk of being ousted from your Farms in this Colony, by the next rich foreigner who chooses to take a fancy so to do, unless in the first instance, you come unanimousiy forward and resist these usurpations. It is not my client's intention to wrong any who have purchased Lots of the Doctor, and to guard against the injury which might result to individuals in this respect, I have carefully drawn up the Form of a Bond for a Warantee Deed, which Mr. Waller is at all times ready, without any further consideration, to execute to any person who has, in good faith, bought of the Doctor, prior to the date of this notice, by being applied to at his residence. Mr. Waller does not require one cent of money to be paid to him as a Consideration for his Bondsthe trouble, expense and outlays they have already incurred, with the desire to save all such persons harmless from pecuniary loss, is a good and sufficient Consideration in Law to bind him in the proposed penalty of One Thousand Dollars. See Comyns. Digest, Assumpsit B.

"I am of opinion that $\mathrm{Mr}$. Waller has rights in the premises, which neither Doctor McLoughlin nor even Congress by any retrospective legislation can take away from him; - and therefore, fellow 
citizens, in sincere friendship, I would counsel you to lose no time in applying to him for your new Bonds.

\section{"JOHN RICORD,"}

"Counsellor in the Supreme Court of the United States and Attorney for Alvin F. Waller."

"Dated 20th December, I843."

The following two letters from A. L. Lovejoy to A. F. Waller and from Waller to Lovejoy, each dated March 20, I844, are in reference to the foregoing proclamation by Ricord as attorney for Waller. These letters are in the handwriting of Lovejoy and Waller, respectively. The letter of Waller is shown by the line below Waller's signature to be a copy which he made and kept to show what he had written. These letters are in the possession of the Oregon Historical Society. They were among Waller's private papers at the time of his death.

"To the

"Wallamette Falls 20 Mar. I844."

"Revd. A. F. Waller-

"I have been directed by Dr. McLoughlin to make some enquiries of you in relation to a letter which appears to have been written by yourself to him relative to his claim. Dr. McLoughlin observes in your notice to the People of Oregon words like the following:

" 'It has since been currently reported and quite generally believed that my client had renounced his right in favor of Dr. McLoughlin. This I am authorized to contradict having perused the let- 
ter written by Mr. Waller which not only contains no renunciation but on the contrary is replete with modest and firm assertions of his rights in the premises.'

"Please have the kindness to say whether you wrote such a letter as there referred to and if so. As Dr. McLoughlin has never received anything of the kind allow him through me to solicit a copy thereof and much oblige.

$$
\begin{gathered}
\text { "I am Revd. Sir, } \\
\text { "Your humble and obt. servant, } \\
\text { "A. LAWRENCE LoveJOY." }
\end{gathered}
$$

"Willamette Falls, 20 Mar. I844."

"Mr. Lovejoy.

"Dear Sir:

"The letter referred to in the Notice was one written to Rev. J. Lee in answer to one he wrote me. I think I have never written a line to Dr. McLoughlin on any subject. Mr. Lee I presume has the letter with him.

"I am yours truly,

\section{"A. F. WALLER."}

"Copy of a reply to the within."

The following copy and statement of John Ricord's caveat or notice as attorney for Rev. Alvin F. Waller to Dr. McLoughlin is taken from Mrs. Frances Fuller Victor's volume, The River of the West, page 358: "You will please to take notice that my client, Mr. A. F. Waller, has taken formal measures at Washington to substantiate his claim as a preemptor and actual settler upon the tract of land, sometimes called the Wallamet Falls settlement and sometimes Oregon City, compris- 
ing six hundred and forty acres; and being aware that, although a foreigner, you claim to exercise acts of ownership over said land, this notice is given to apprise you that all sales you may make of lots or other subdivisions of said farm, after the receipt hereof, will be regarded by my client, and by the government, as absolutely fraudulent, and will be made at your peril.'"

Then followed the grounds upon which the Doctor's claim was denied. "First, that he was an alien; Secondly, that he was the chief of a foreign corporate monopoly; Thirdly, that he had not resided upon the land in question for a year previous; Fourthly, that he did not hold the land for himself but the Company; Fifthly, that his claim, if he had any, arose two years subsequent to $\mathrm{Mr}$. Waller's settlement thereon. This flattering document closed with Mr. Ricord's regrets that he had 'failed to make an amicable compromise' of the matter between the Doctor and his client, and also that his 'client had been driven to the vexatious proceedings of the law, in order to establish his rights as an American citizen." "This caveat or notice was served on Dr. McLoughlin in 1844 prior to April 4, after Ricord left Oregon for the Sandwich Islands.

The attempt of Rev. A. F. Waller to assert any right to, or to procure the land claim of Dr. McLoughlin, or any part of it, at Oregon City, under the law relating to pre-empting lands was absurd as well as invalid. Under the act of Congress of September $4,184 \mathrm{I}$, then in force, relating to the pre-emption of public lands of the United States, it 
was necessary that the lands should be a part of the public lands of the United States. The Conventions of joint-occupancy were then in force and neither Great Britain nor the United States exercised jurisdiction over the lands in the Oregon Country.

In addition to other requisites of the pre-emption law, no person could pre-empt more than one hundred and sixty acres, and the law required the intending pre-emptor "to enter with the Register of the Land-Office for the district in which such land lies, by legal subdivisions, any number of acres not exceeding one hundred and sixty, or a quartersection of land," etc.

There was no United States land district in Oregon nor any Register of any United States landoffice. There had been no public surveys of land in Oregon. No lands could be legally pre-empted which had not been officially surveyed by authority of the United States. ${ }^{63}$

In the case of Lytle v. State of Arkansas, 9 Howard (U. S. Supreme Court) 3I4, it was held, concerning a claim to pre-emption, that "until sanctioned by law, it has no existence as a substantive right." In the case of Brown v. Coursen, i6 Oregon, 388 , it was held that a pre-emption is a right derived wholly from statute and a substantial compliance with the statute is necessary; and the condition must exist which would enable the preemptor to acquire the land under the statute. In

\footnotetext{
'Dernard's Heirs v. Ashley's Heirs, 18 Howard (U. S. Supreme Court) 43; Hot Spring Cases, 2 Otto (U. S. Supreme Court) 698, 706.
} 
the case of Stark v. Starrs, 6 Wallace (U. S. Supreme Court) 402, it was held that even the act of August I4, 1848, organizing the Territory of Oregon, did not extend over Oregon any portion of the preëmption act of September 4, I84I.

Ricord and Rev. Jason Lee sailed on the same vessel from the Columbia River bound to the Hawaiian Islands. They left Oregon City January 4, but did not cross the Columbia River bar until February 3, 1844. Ricord did not intend to return to Oregon. He made his home at the Hawaiian Islands (then called Sandwich Islands) and died there. Rev. Jason Lee intended merely to make a trip to the Eastern States and return to Oregon. He wished to see the Missionary Board in New York. He also wished to go to Washington to see about land matters, particularly those which the Methodist Mission wished to obtain the title to. When he arrived at Honolulu he first learned that he had been removed as Superintendent of the Oregon Mission, and that Rev. George Gary was on his way to take charge. February 28, 1844, Rev. Jason Lee sailed on a small schooner called the "Hoaikaika" for Mazatlan, Mexico. ${ }^{64}$ After his arrival at Mazatlan, Jason Lee crossed Mexico. He arrived in New York May 27, I844. In June he went to Washington. On his return to New York he appeared before the Missionary Board for several days, beginning with July I, I 844, and submitted his oral report on the Oregon Mission.

As relating to land claims in Oregon, I make the following excerpts from two letters written by

${ }^{84}$ Rev. Gustavus Hines, History of Oregon, Chapter $\mathrm{x}$. 
Rev. Jason Lee after leaving Oregon. The originals of these letters are in the possession of the Oregon Historical Society. The first of these letters was written on board the schooner Hoaikaika, March 23, I844, to Rev. A. F. Waller. In this letter Jason Lee says: "I paid Mr. Ricord Two hundred and Fifty dollars for you and shall inclose your order to Bro. Abernethy. . . . What the result of your land claim will be, of course, I can form no better opinion than when I left. But I have less hopes of effecting anything for the Mission more than to prepare the way for something to be done at the proper stage, that is, whenever the Government shall be prepared to grant title. - I long to hear how you are getting on with Dr. — \&c., and how the good cause is prospering. May the Lord bless all who have embraced his cause and keep them unto 'that day.' "

The second of these letters is to Rev. Gustavus Hines. It is dated at New York July I, I 844, and written after the return of Rev. Jason Lee from Washington. He wrote: "Met a favorable reception there [Washington] and there is every reason to expect that the land claimed will be cheerfully accorded to us. . . . Please tell Bro. Waller that his claim is filed in the Office of the Commissioner General of the land office. This will probably secure his claim, though the Supreme Court will probably take no action till an Oregon Bill passes." Waller, however, had "surrendered" all his rights in "his" (the McLoughlin) "land claim" April 4, I $844 .{ }^{65}$

\footnotetext{
${ }^{65}$ See Document J.
} 


\section{DOCUMENT J}

Agreement between Dr. John McLoughlin, Rev. A. F. Waller, and Rev. David Leslie, of April 4, I844; statement of cause and manner of making said agreement.

The following agreement is in the possession of the Oregon Historical Society. It was among the private papers of Rev. A. F. Waller at the time of his death. This instrument is certified to be a true copy of the original by W. W. Raymond, one of the lay Methodist missionaries. Apparently there was but one original of this instrument, although executed by Dr. McLoughlin, Rev. Alvan F. Waller and Rev. David Leslie, and therefore a copy was made of the same and certified by Raymond for Waller's use.

\section{ARTICLES OF AGREEMENT}

"ARTICLE OF AGREEMENT made and entered into this fourth day of April A. D. I844 between John McLoughlin and Alvan F. Waller both of Oregon City in the Territory of Oregon:

"Whereas certain conflicting claims to a tract of land situated at the Falls of the Wallamette River on the east side of said River containing six [hundred] and forty acres and surveyed by Jesse Applegate in the month of December A. D. I 843 have existed between the aforesaid parties and the said parties are now willing and desirous to arrange all differences existing between them in regard to the same;

"It is therefore agreed as follows: The said Al- 
van $F$. Waller agrees to surrender make over and forever abandon unto the said John McLoughlin his heirs administrators and assigns and in his favor, all claims rights and pretensions whatsoever which he now has within or to the said above mentioned Tract or survey of land or any part thereof. The said Waller further agrees to withdraw any proceedings which he or his attorney may have commenced in any of the courts of the United States touching the said tract or survey of land and to abstain from at any future time instituting any proceedings to secure to himself the title of the said tract or survey of land in opposition to the said McLoughlin or to his detriment in any way whatsoever, or to sell or otherwise dispose of to any person whatsoever other than the said McLoughlin any claim or right which he the said Waller may have in the same.

"And the said John McLoughlin agrees in consideration of the above mentioned acts and agreements on the part of the said Alvan F. Waller to pay to the said Waller the sum of five hundred dollars and further to convey to the said Waller the premises now occupied by him being lots number two and seven in Blocks number one in Oregon City in said survey - also the entire Blocks numbers fifty four, forty one and eighteen and lots one, two, three, six, seven, and eight in Block number eleven all included in the plot Oregon City aforesaid; and the said John McLoughlin further agrees to give to said Alvan F. Waller his Bond conditioned for a good and sufficient Warrantee Deed to all the above specified premises.

"And the said John McLoughlin further agrees 
to convey to David Leslie now acting superintendent of the Oregon Methodist Episcopal Mission lots three, four, five and six in Block number one and also lots numbers four and five in Block twenty eight and also the entire Block number twenty nine on the plot of Oregon City aforesaid; and the said John McLoughlin further agrees to give to the said David Leslie his Bond conditioned for a good and sufficient warrantee deed accordingly to all the above specified premises.

"Signed with our names and sealed with our seals this day and year first above mentioned.

$$
\begin{aligned}
& \text { "John McLoughlin" } \\
& \text { "Alvan F. WAlleR" } \\
& \text { "David Leslie" S. }
\end{aligned}
$$

"Witnesses"

$$
\begin{aligned}
& \text { "James Douglas" } \\
& \text { "EliJAH White" } \\
& \text { "A. L. LovejoY" } \\
& \text { "W. GilpiN." }
\end{aligned}
$$

"True Copy of the original.

"Attest:

W. W. RAYMOND.

"Wallamette Falls July 24, I844."

A copy of the bond, dated April 4, 1844, given by Dr. John McLoughlin to Rev. A. F. Waller, as provided in said Articles of Agreement of the same date, is in the possession of the Oregon Historical Society. It is also certified to be a true copy by said W. W. Raymond. This certified copy was, also, among the private papers of Rev. A. F. Waller at the time of his death.

Frances Fuller Victor, who had access to orig- 
inal documents, says that the reasons why the agreement set forth in this Document J, came to be entered into are as follows: In April, I844, Dr. Elijah White suggested that the differences between Dr. McLoughlin and A. F. Waller about the Oregon City land claim might be settled by arbitration. Dr. McLoughlin finally consented to this plan. The arbitrators chosen were Dr. Elijah White, Major Gilpin, and James Douglas, on the side of Dr. McLoughlin, and Revs. David Leslie and A. F. Waller on the side of Waller and the Methodist Mission. All the arbitrators, except Douglas, were citizens of the United States. Major Gilpin had attended West Point and had been an officer in the regular army of the United States. He came to Oregon with Fremont's expedition. Rev. David Leslie was then the acting Superintendent of the Methodist Mission.

Waller insisted that he should receive five hundred dollars and five acres for himself and the Methodist Mission should receive fourteen lots. White and Gilpin considered this exorbitant and opposed it. They were finally persuaded by Douglas to agree to Waller's terms. Douglas said to Dr. McLoughlin, "I thought it best to give you one fever and have done with it. I have acceded to the terms and signed the papers." 66

While Dr. McLoughlin signed these agreements and executed these bonds and carried them out as far as he was able to, he was not pleased with being compelled to accede to these demands,

${ }^{\circ 0}$ Mrs. Frances F. Victor, The River of the West, pp. 359, 360;
History of Oregon, Bancroft's Works, Vol. r, p. 223. 
which he considered unjust. If Waller, either for himself alone or for himself and the Methodist Mission, were entitled to the 640 acres of Dr. McLoughlin's land claim, Waller and it should have insisted on having the whole claim. The proposition of Waller to accept $\$ 500$ and five acres of land and for Dr. McLoughlin to give the Mission fourteen lots shows that in the minds of Waller and the Mission his and its claims were, to say the least, very dubious ones. Dr. McLoughlin could but consider that he had been forced to comply with these demands, not as a question of right, but as a question of expediency and to get rid of these false claims.

\section{DOCUMENT K}

Statement of the career in Oregon of Judge W.P. Bryant.

I have been unable to learn much about Judge W. P. Bryant, except his actions in connection with Abernethy Island and against Dr. McLoughlin. To his Biennial Report of I899 (page 190) Hon. H. R. Kincaid, as Secretary of State for Oregon, added an Appendix giving short biographies of the Chief Justices of Oregon and of other Oregon officials. Of Judge Bryant the Secretary of State said only: "There are no official records in the Department of State to show when Mr. Bryant assumed the duties of his office nor for what period he served. The decisions of the Supreme Court at the time when he served were not reported. Mr. Bryant was appointed by the Presi- 
dent from some eastern state and only served here a short time when he again returned east."

In the History of Oregon in Bancroft's Works, it is said: That Judge Bryant's home was in Indiana; that he was appointed Chief Justice of Oregon in August, I848, and arrived in Oregon April 9, 1849; that he resigned as Chief Justice January $\mathrm{I}, \mathrm{I} 85 \mathrm{I}$, having spent but five months in Oregon; that upon his resignation he returned to Indiana, where he soon died.

\section{DOCUMENT L}

Letter of Dr. John McLoughlin, published in the "Oregon Spectator," Thursday, September I2, I850.

"Mr. Editor:

"In the Congressional Globe of May 30th, I850, is the following language of Mr. Thurston, the Delegate from Oregon, to which I wish to invite the attention of the public.

" 'And as to the humbug about the Hudson's Bay Company, mentioned by the gentleman from Missouri [Mr. Bowlin], I have to say that I know of no humbug about it; this Company has been warring against our Government for these forty years. Dr. McLoughlin has been the chief fugleman, first to cheat our Government, out of the whole country, and next to prevent its settlement. He has driven men from their claims, and from the country, to stifle its efforts at settlement. In I 845 he sent an express to Fort Hall, eight hundred miles, 
to warn the emigrants, if they attempted to come to the Willamette, they would all be cut off; they went and none were cut off. How, sir, would you reward Benedict Arnold, were he living; he fought the battles of the country, yet, by one act of treason, forfeited the respect of that country. A bill for his relief would fail, I am sure; yet this Bill proposes to reward those who are now, have been, and ever will be, more hostile to our country, because more Jesuitical."

"What Mr. Thurston means by 'warring against our government for these forty years,' I know not. I am certain, however, that the H. B. Co. had a right to carry on trade under the treaty of joint occupation of the country - even were we to look no farther for another foundation of the right. I am sure, moreover, that the business of the Company was so managed as to bear the strictest scrutiny, and to be in all respects subservient to the best interests of the country, and the duties of religion and humanity. The government and policy of the Company were such as to render traveling safe, and the Indians were friendly to whites. When the Hudson's Bay Company first began to trade with these Indians they were so hostile to the whites that they had to mount guard day and night at the establishment, have sentinels at the gates to prevent any Indian entering, unless to trade, and when they entered, to take their arms from them. The Columbia could not be traveled in parties of less than sixty well armed men; but, by the management of the Company, they were brought to that friendly disposition that two men, 
for several years back, can travel in safety between this and Fort Hall.

"Mr. Thurston is pleased to describe me as 'chief fugleman to the Hudson's Bay Company.' This is a term which he probably gathered from the vocabulary in which he found the word 'gumption,' with which he recently garnished another dish, and which he seems to have prepared for appetites similar to his own. By the use of this, and such like epithets it will at once be seen that he has a field of literature which he is likely to occupy without a rival, and the exclusive possession of which no one will deny him. Neither my principles nor my tastes lead me in that direction. But I am described as a 'fugleman' of the Hudson's Bay Company; first to cheat our Government out of the whole country, and next to prevent its settlement. I am an old man, and my head is very white with the frost of many winters, but I have never before been accused as a cheat. I was born a British subject - I have had for twenty years the superintendence of the Hudson's Bay Company's trade, in Oregon, and on the North West Coast; and may be said to have been the representative of British interests in this country; but I have never descended to court popularity, by pandering to prejudice, and doing wrong to anyone. I have, on the other hand, afforded every assistance to all who required it, and which religion and humanity dictated; and this community can say if I did so or not. My language to all who spoke to me on the subject of politics, was that situated as we were we ought to say nothing about the boundary ques- 
tion, as that was an affair of the Government; but to live as Christians in peace and concord, and in acting as I did I consider that I have rendered services to the British and American Governments. But if I had acted differently, the Government would have had difficulties, and this community would perhaps not have enjoyed the peace it has, nor be in so prosperous a condition as it is, and certainly there is not a man in it who will say that I have sought to prevent its settlement. There are, in this Valley, very many persons, and especially among the earliest immigrants, of the first years of the settlement of the country, who are sufficiently honest to admit that the country could never have been colonized as easily as it was, but for the timely, ample, and continuous assistance rendered by me, to them, with the means of the Hudson's Bay Company under my charge. Provisions were sent to meet the immigrants-boats were dispatched to convey them down the Columbia,when arrived on their claims, cattle were loaned them - they were supplied with clothing, food, farming utensils, and wheat for seed. Very many of these men honorably paid, as soon as they could; others, though able to pay, and though their notes have been standing for many years, testify their sense of the number and magnitude of my favors by signing a secret Memorial to the Congress of the United States, to take from me my property, and to leave me in the decline of life, and in the decrepitude of old age, to the companionship of adders, who-when they were benumbed with frost, I gathered from the hedges and warmed 
into life, to feel, when alas! too late, the stings of their ingratitude.

"For additional proof, in repelling these calumnies, I could refer to many sources: Wilkes' Journal, Fremont's Narrative, to American travelers and writers, and to letters from many and many an immigrant to this country, and now residents in this valley, stating to their friends in the States the kindness I had shewn them, and who, I am sure, would acknowledge it, and are as much surprised at the charge brought against me as I am myself. But, moreover, it is well known that the fact of my having aided in the settlement of this country has been a subject of serious complaints, and grave charges made against me, by subjects of Her Britannic Majesty, during the pending of the boundary question - who seem to have been imbued with the same kind disposition toward their fellow men as Mr. Thurston.

"Mr. Thurston says, 'In 1845 he [Dr. McLoughlin] sent an express to Fort Hall, eight hundred miles, to warn the immigration that if they attempted to come to the Willamette, they would be all cut off.' This is a calumny as gratuitous as it is unprovoked; but it is with mingled emotions of astonishment and indignation that I have accidentally become acquainted with the contents of another document, entitled a 'Letter of the Delegate from Oregon to the members of the House of Representatives, in behalf of his constituents touching the Oregon Land Bill.' On the back of the only copy sent, is written in the handwriting of Mr. Thurston - 'Keep this still till next 
mail, when I shall send them generally. The debate on the California Bill closes next Tuesday, when I hope to get it and passed-my land bill; keep dark till next mail.

"'Thurston.'"

"'June 9, I8 5o.'"

"In the paragraph already quoted from the Globe of June 30, Mr. Thurston affirms that I am a more dangerous man than Benedict Arnold was; because, as he states, I am more 'Jesuitical.' Webster, the celebrated American Lexicographer, defines Jesuitism thus: 'Cunning, deceit, prevarication, deceptive practices'-yet this same man, Mr. Thurston, who bestows epithets upon me without stint and beyond measure; who accuses me of being 'Jesuitical,' and who occupies the situation of a grave legislator, admits that his measures will not bear the light of truth, and he requires his friend to keep still, until he shall complete the perpetration of a deed of wickedness. Is this not the cunning of the fox? who prowls around in the darkness, that he may rob the hen-roost of the farmer while he is sleeping, without a suspicion of a meditated evil. Is not the sending of such a document, with the request written upon it to keep 'dark,' a deceptive practice, within the very letter and meaning of Webster's definition of Jesuitism? Mr. Thurston, it appears, was afraid of the light of facts, which he did not desire to have communicated to the Government at Washington, before he completed an act of contemplated wrong doing.

"In the letter referred to, speaking of Oregon City, he says, 'The Methodist Mission first took the 
claim with the view of establishing here their Mills and Mission - they were forced to leave it under the fear of having the savages of Oregon let loose upon them.' This charge is likewise without a fraction of truth, as a few facts will demonstrate. In 1829 , I commenced making preparations at the falls of the Willamette, for building a sawmill. I had a party residing there during the winter of 1829 and 1830 . This party, in my employment, and paid with my money, built three houses, and prepared the timber for the erection of a mill. Circumstances rendered the suspension of the mill for a while necessary. In the spring of 1830 I commenced cultivating the ground at the Falls. In the year 1832 I had a mill race blasted out of the rocks, from near the head of the island which Mr. Thurston calls Abernethy Island-but Mr. Thurston found it convenient to conceal from the United States Government that Mr. Abernethy and others purchased the island from F. Hathaway, who jumped the island in the first instance, and that Judge Bryant and Gov. Lane finally purchased whatever right Mr. Abernethy had acquired. The Indians having burnt in 1829 the timber which during that same year had been prepared for the erection of the mill, I had, in the summer of 1838 , another house built at the Falls; during the same year I had squared timber prepared and hauled to the place at which I had originally proposed to erect a mill; the erection of the mill was again postponed. In 1840 the Rev. Jason Lee, superintendent of the Methodist Mission in Oregon, applied to me for the loan of some 
of the above mentioned timber, for the purpose of erecting a Mission building. To this request I assented, and at the same time sent Dr. F. W. Tolmie to point out to the Rev. Mr. Lee the spot upon which he might build. Up to this time, it should be observed that no effort had been made to interfere with my claim, and no one called in question my perfect right to make it. It should be borne in mind, too, that I commenced improving in 1829 , and that the missionaries did not come here till 1834 . To prevent, however, any future misunderstanding, growing out of any occupancy of sufferance, I handed Mr. Lee a letter, dated Vancouver, 2Ist July, I840, in which I described the extent of my claim, as embracing 'the upper end of the Falls, across to the Clackamas Falls, in the Willamette, including the whole point of land and the small Island in the falls, on which the portage is made and which I intend to claim when the boundary line is drawn.' The words italicised are not so in the original. I now do this to call attention to them. Up to this time no one but myself claimed the island. Mr. Lee promised to return the timber he procured to erect the building, with the wood thus loaned Mr. Waller and family, who were placed in it by Mr. Lee. I gave Mr. Lee permission to occupy, as a mission store room, a house I had got erected for myself. Up to I $84 \mathrm{I}$ my claim to the island had never been interfered with; in this year Mr. Felix Hathaway put some logs on the island. I gave him notice of my claim, and erected a small house upon the island. Hathaway finally proceeded with his building. I did 
not forcibly eject him because I wished to preserve the peace of the country. In the autumn of 1842 , I first heard that the Rev. Mr. Waller, as I was informed, set up a claim in conflict with mine, (not for the Mission, but in his own name.) I subsequently bought off Mr. Waller, in the same anxious desire to preserve the peace.

"In conclusion of this part of the subject I will remark that when Mr. Waller requested Capt. W. $\mathrm{K}$. Kilbourn, who resides in this place, to assist him in putting up the logs which I had loaned to Mr. Lee, Capt. Kilbourn said to him: 'I will not assist to build the house, if you intend to set up any claim here.' Mr. Waller disavowed any such intention.

"In I 842 I had the claim surveyed by Mr. Hudspath, and laid off some lots; in the fall of 1843 , there being better instruments in the country, I had my claim surveyed by Jesse Applegate, Esq., who more accurately marked its streets, alleys, lots, etc., etc. When the Oregon Provisional Government was formed, I recorded my claim in accordance with the provisions of its organic laws; this record covers the island and the site of Oregon City. In making this record, I circumscribed the limits of my claim, so that instead of extending down to the Clackamas River, as I had made it previous to there being any government in the country, I made it so as to extend only about half way down. This I did because the Organic Law provided that no one should hold more than six hundred and forty acres. This I did also for the sake of peace, notwithstanding Mr. Thurston is not ashamed to 
more than intimate a disposition to 'let loose upon them savages of Oregon.' Mr. Thurston says, 'He has held it by violence and dint of threats up to this time.' - That I have held my claim or any part of it by violence or threats, no man will assert, and far less will one be found to swear so, who will be believed on his oath, in a court of justice. I have probably no other enemy than Mr. Thurston, so lost to the suggestions of conscience as to make a statement so much at variance with my whole character.

"He says that I have realized, up to the $4^{\text {th }}$ of March, I849, \$200,000 from the sale of lots; this is also wholly untrue. I have given away lots to the Methodists, Catholics, Presbyterians, Congregationalists, and Baptists. I have given 8 lots to a Roman Catholic Nunnery, 8 lots to the Clackamas Female Protestant Seminary, incorporated by the Oregon Legislature. The Trustees are all Protestants, although it is well known I am a Roman Catholic. In short, in one way and another I have donated to the county, to schools, to churches, and private individuals, more than three hundred town lots, and I never realized in cash $\$ 20,000$, from all the original sales I have made. He continues, 'He is still an Englishman, still connected with the Hudson's Bay Company, and refuses to file his intentions to become an American citizen.' If I was an Englishman, I know no reason why I should not acknowledge it; but I am a Canadian by birth, and an Irishman by descent. I am neither ashamed of my birth-place or lineage - but it has always appeared to me that a man who can only boast of his country has little to be proud of: 
" 'A wit's a feather, a chief, a rod -

An honest man's the noblest work of God.' ",

"I was a Chief Factor in the Hudson's Bay Company's service, and by the rules of the Company, enjoy a retired interest, as a matter of right. - Capt. McNeil, a native born citizen of the United States of America, holds the same rank as I held in the Hudson's Bay Company service. He never was required to become a British subject; he will be entitled, by the laws of the Company, to the same retired interest, no matter to what country he may owe allegiance.

"I declared my intention to become an American citizen on the 3 oth May, I849, as any one may see who will examine the records of the court, in this place. Mr. Thurston knew this fact-he asked me for my vote and influence. Why did he ask me for my vote if I had not one to give? I voted and voted against him, as he well knew, and as he seems well to remember. But he proceeds to rerer to Judge Bryant for the truth of his statement, in which he affirms that I assigned to Judge Bryant, as a reason why I still refuse to declare my intention to become an American citizen, that I cannot do it without prejudicing my standing in England. I am astonished how the Supreme Judge could have made such a statement! as he had a letter from me pointing out my intention of becoming an American citizen. The cause, which led to my writing this letter, is that the island, called Abernethy's Island by Mr. Thurston, and which he proposes to donate to Mr. Abernethy, his heirs and assigns, is the same island which $\mathrm{Mr}$. Hathaway and others jumped in $184 \mathrm{I}$, and formed 
themselves into a joint stock company, and erected a saw and grist mill on it, as already stated. From a desire to preserve peace in the country, I deferred bringing the case to trial, till the government extended its jurisdiction over the country; but when it had done so, a few days after the arrival of Judge Bryant and before the courts were organized, Judge Bryant bought the island of George Abernethy, Esq., who had bought the stock of the other associates, and as the Island was in Judge Bryant's district, and as there was only two judges in the Territory, I thought I could not at the time bring the case to a satisfactory decision. I therefore deferred bringing the case forward to a time when the bench would be full. In July or August, I849, Gov. Lane told me Judge Bryant would speak to me in regard to my claim on the Island; the Judge did so and asked me to state the extent of my claim. To avoid mistakes and misunderstandings, to which verbal communications are subject, I told him I would write him, and accordingly addressed him the following letter:

\section{"Oregon City, 2ist Aug. i849."}

"To the Hon. W. P. Bryant:

\section{"Sir -}

"I hasten to comply with your request, "that I state the extent of my claim to the Island within ten days,' and I beg to refer you to the books of recorded land claims, kept by Theo. McGruder, Esq., for the extent of my claim; and I shall expect a transfer of the fee simple of the whole ground, with all and every privilege from the United States 
of America, as soon as it shall meet the pleasure of my adopted government to act in the matter.

"I have the honor to be

"Your obedient humble servant,

[Signed] "John McLoughlin."

"This letter was handed to Judge Bryant by J. D. Holman, Esq., and it seems quite incomprehensible to me, how, after receiving and perusing this letter, Judge Bryant could corroborate (if he did so) Mr. Thurston's statement, that I had declined to file my intention to become an American citizen. I filed my intention on the 3oth May. Mr. Thurston left this (Territory) in August, and Judge Bryant in October. Is it probable! nay, is it possible! in so small a place as Oregon City, where every little occurrence is so soon known where the right of voting is so scrutinized - that I should have voted, and against Mr. Thurston, and that his partisans and supporters did not inform him of it, or that Judge Bryant did not know that I had filed my intention to become an American citizen? But Mr. Thurston makes another statement in which there is not more truth. He says, 'Last summer he,' meaning myself, 'informed the writer of this that whatever was made out of the claim was to go to the common fund of the Hudson's Bay Company, of which he and other stockholders would share in proportion to their stock; in other words, that he was holding this claim in trust for the Hudson's Bay Company.'

"Mr. Thurston had just before said that I had made for myself $\$ 200$,ooo from the sale of lots; but 
now after having made my conservative purse vastly capacious finds it convenient to shrivel it up by transferring this cheering amount of coin to the coffers of the Hudson's Bay Company. I assert I never made such a statement to Mr. Thurston, and I assert that I hold my claim for myself alone, and that the Hudson's Bay Company, nor no other person or persons, hold or have any interest in it with me.

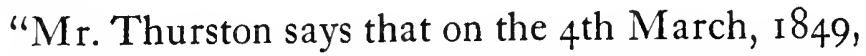
Governor Lane apprised Dr. McLoughlin and all others that no one had a right to sell or meddle with government lands. This is given as a reason why every man that has bought a lot since that time shall lose it. If by this statement anything more is meant than at that date the Territorial government was put in operation, then it is wholly untrue; but were it otherwise, what is the motive for the commission of such an act of injustice that necessarily involves in pecuniary loss half the inhabitants of this place, in addition to many who do not reside here? Mr. Thurston says, Abernethy's Island is in the middle of the river. Such a statement could only be made to persons unacquainted with this place, and conveys a wrong impression, as every one who knows the place will admit the island is not in the middle of the river, but separated from the main land only by a chasm over which there is a bridge about Ioo feet long. In the dry season, the stream is not more than forty feet broad at the Falls, which separates it from the main land, and can the people of Oregon City and its vicinity believe Mr. Thurston did not know, some months 
before he left this, that Mr. Abernethy had sold his rights, whatever they were, to Judge Bryant, and therefore proposing to Congress to donate this Island to Mr. Abernethy, his heirs and assigns, was, in fact, proposing to donate it to Judge Bryant, his heirs and assigns.

"Jno. McLoughlin."

"[At the request of Dr. McLoughlin, we stepped into the Clerk's office and read upon a paper filed in the office that on the 3oth day of May, I849, John McLoughlin filed his intention to become an American citizen, and that the said paper was duly certified to, by the then acting Clerk, Geo. L. Curry. - ED.]"

\section{DOCUMENT M}

Letter by William J. Berry, published in the "Oregon Spectator," December 26, I850. "Forest Creek, Polk Co., December I 5, i $850 . "$ "Mr. Editor:

"Truth crush'd to earth, shall rise again: The eternal years of God are hers;

But error, wounded, withers with pain, And dies among his worshippers."

"Believing that the characters of public men are public property, I desire, with your permission, to speak through the columns of the 'Spectator' about some of the doings of our Delegate in Congress.

"I am dissatisfied with his course in regard to the 'Oregon City Claim.' And now permit me to say, that I am not influenced in this matter by mercenary motives of any kind. I never owned any 
property in or about Oregon City, nor do I ever expect to; but I am influenced by motives of a certain kind, which are: the veneration I feel for the sacred principles of truth and justice,-and the mortification $I$ feel at seeing these principles not only overlooked, but indignantly trampled under foot.

"Up to the time of writing his celebrated "letter to the members of the House of Representatives,' $\mathrm{I}$, in common with a large portion of the people here, was led to admire the ability, the zeal, and industry, with which $\mathrm{Mr}$. Thurston conducted the business of this Territory. But in that portion of said letter, where he speaks of the Oregon City claim, I think he has placed himself in the position of the old cow, who, after giving a fine pail of milk, kicked it all over. With the disposal of said claim as contemplated in the bill, I have no fault to find; but with the means employed by $\mathrm{Mr}$. Thurston to effect that end, I do find most serious fault.

"Some of these I will notice. Speaking of Dr. McLoughlin, he says: 'He still refuses to file his intentions to become an American citizen.' Now, I assert that Mr. Thurston knew, previous to the election, that Dr. McLoughlin had filed his intentions. I heard him say in a stump speech, at the City Hotel, that he expected his (the Doctor's) vote. At the election I happened to be one of the Judges; Dr. McLoughlin came up to vote; the question was asked by myself, if he had filed his intentions? The Clerk of the Court, George L. Curry, Esq., who was standing near the window, 
said that he had. He voted. Some time after the election, when I was holding the office of Justice of the Peace, in Oregon City, Mr. Thurston came to me, in company with a man whose name I have forgotten, having an affidavit already prepared which he wished sworn to, and subscribed by this man; which was done. Said affidavit went to state that Dr. McLoughlin had written a letter, or letters, to some French settlers north of the Columbia, directing them to oppose Thurston and vote for Lancaster, \&c., \&c. I merely mention this circumstance to show that $\mathrm{Mr}$. Thurston knew exactly how Dr. McLoughlin stood. The assertion of Mr. Thurston that Dr. McLoughlin has 'worked diligently to break down the settlements,' is also without foundation. There are scores of persons in this valley of the early emigrants, who testify to the kindness received at the hands of Dr. McLoughlin. And many there are who would doubtless have perished had it not been for his humane attention. He helped them to descend the Columbia - fed them, clothed them; and now he is accused of 'working diligently to break down the settlements!'

"I shall notice but one more of Mr. Thurston's assertions in regard to this claim. Mr. Thurston says: 'The Methodist Mission first took this claim.' Now this is an assertion which any one who knows anything about the history of Oregon City, knows to be utterly without foundation. - On the contrary the said Methodist Mission never had a right to any part of said claim, unless jumping constitutes right. 
"In what I have said about Dr. McLoughlin, I have not spoken from interested motives. I never received any favor at his hands, nor do I expect to. But I am ashamed of the course of our Delegate; I think it is unbecoming the Representative of a magnanimous people.

"What must be the feelings of Dr. McLoughlin? A man whose head is whitened by the frosts of perhaps eighty winters! Who, during that long period has been living subject to the nation under whose flag he was born. And who, at that advanced age declares his intention of becoming a citizen of our great Republic. - I say what must be his feelings? and what must be the feelings of all candid men of all men of honor and magnanimity, who have read Mr. Thurston's letter. And yet this same Honorable (?) Delegate in his address to his constituents lectures us upon Religion and Morality. "Very respectfully, yours, "WM. J. BERry."

\section{DOCUMENT $\mathrm{N}$}

Excerpts from speech of Samuel $R$. Thurston in Congress, December 26, I850.

December 26,1850 , Thurston attempted to answer, by a speech in Congress, Dr. McLoughlin's letter, published in the Oregon Spectator, September I2, I 850. It is a scurrilous speech. Most of its asserted statements of fact are untrue. It is too long to be set forth here in full. It will be found at pages 36 to 45 of the Appendix to volume 23 of 
the Congressional Globe. The italics in this Doc. ument $\mathrm{N}$ are those appearing in the Congressional Globe.

He first discussed the petition of the fifty-six persons who signed the petition at Oregon City, September 19, 1850, against the passage of the eleventh section of the Donation Land Bill, and attempted to show that the petition was against Dr. McLoughlin instead of being in his favor. This was pettifogging. Thurston set forth that he had not been in favor of recognizing in the bill transfers of land by Dr. McLoughlin after March 3, I 849, for the reason that "If such transfers were confirmed in general terms, up to the passage of the bill, the whole of what the Doctor claimed would be covered by fictitious transfers for his benefit." Thurston attacked J. Quinn Thornton and Aaron E. Wait, the attorneys of Dr. McLoughlin, and called them names too vile to be inserted in this address.

Referring to Dr. McLoughlin's statement in his letter that the Hudson's Bay Company's business was so managed "in all respects subservient to the best interests of the country, and the duties of religion and humanity," Thurston said: "If to make the settler pay with his life the penalty of settling where they did not want him to, or to oppress him until he was compelled to yield; if tearing down houses over families' heads, and burning them up, and leaving a poor woman in the rain, houseless and homeless; if attempting to break down all American enterprises, and to prevent the settlement of the country - if, sir, to do all these things, 
and many more, which are hereafter proved, then is the quotation true. If this is their religion, then have they adorned, for the last ten years, the religion they profess." These charges are maliciously false.

Thurston charged that Dr. McLoughlin was "for all practical purposes, as much in, of, and connected with the [Hudson's Bay] Company as he ever was. . . yet he comes up here with a hypocritical face and pleads poverty! and says that he has picked up my people out of ditches, mudpuddles, from under the ice, and warmed them into life; which Wait and Thornton virtually testify to. . . . Who ever heard a Jew or a Gypsy making up a more pitiful face than this." Thurston further said that Dr. McLoughlin persuaded some of the immigrants of 1842 to go to California; that he provided outfits for them "and took notes, payable in California. And this was done for the purpose of ridding the country of these unwelcome visitors. . . . That the Doctor was determined to do all he could to prevent the country from finally settling up, and with this object in view, undertook to persuade our early settlers to leave." This is absolutely untrue, except the part that Dr. McLoughlin furnished said immigrants with outfits and took their notes payable in California. Most of these notes were never paid.

Thurston then proceeds to pettifog about his injunction to keep his letter to Congress about the Donation Land Bill "dark till next mail." $\mathrm{He}$ had to pettifog or say it was a forgery. He said he wrote this as he feared the bill "never would 
pass, and I dreaded the effect the news of its failure, on the first day, would have on business of the territory. . . . It was to avoid the general panic that I adopted this course and this is why I requested to have nothing said till the time of trial might come." ${ }^{67}$ Thurston was compelled to admit that he knew that Dr. McLoughlin had taken the oath of allegiance to the United States prior to the election in June, I 849 , but Thurston said he did not know that Dr. McLoughlin had filed his intentions to become a citizen. Thurston endeavored to justify himself by technicalities. He knew that the Circuit Courts of the Provisional Government had ceased to exist May I3, I849, or prior thereto. It was on that day that Governor Lane assigned the Territorial judges, appointed by the President, to their respective districts. Yet Thurston asserted that "The court, or the tribunal, in which Dr. McLoughlin took his oaths was not such a court as the law requires, but was a creature of the Provisional Government." $\mathrm{He}$ asserted that George L. Curry, the Clerk of the court, before whom Dr. McLoughlin took the oath of allegiance and filed his intentions to become an American citizen, did it in his capacity as a clerk of a court of the Provisional Government (which was no longer in existence), instead of in the capacity of a clerk of the new Territorial court, and said that Judge Bryant informed him that this was the case.

May 30, I 849, George L. Curry, if not the $d e$ jure clerk, was the de facto and acting clerk of the

${ }^{67}$ See Document L, where this injunction by Thurston, written on the copy of his letter, is set forth in full. 
Territorial District Court, before whom it was lawful and proper to take the oath of allegiance under the United States naturalization law. If, for any reason, Dr. McLoughlin did not comply technically with the law, it was nevertheless his intention to do so. He subscribed and filed two oaths on May 30, 1849 . In these he swore it was his intention to become an American citizen and that "I renounce all allegiance and fidelity to any foreign Prince, Potentate, State and Sovereignty, whatsoever and particularly to Victoria, Queen of the United Kingdom of Great Britain and Ireland, and that I will support the Constitution of the United States, and the provisions of "An Act to establish the Territorial Government of Oregon.' " Under these oaths, or one of them, Dr. McLoughlin became a citizen of the United States September 5,1851 . In admitting him to citizenship the Judge must have found that Dr. McLoughlin's original declaration was sufficient and was filed in a court of competent jurisdiction. And yet Thurston had said in his letter to the House of Representatives and in his speech of May 28, 1850, that Dr. McLoughlin "refuses to become an American citizen."

In this speech of December 26, 1850 , Thurston said that if any persons in Oregon owed money to Dr. McLoughlin, he could proceed in the Courts. This is true. The difficulty was to enforce judgments. Judgments could not then or prior to that time and until long afterwards be enforced against land. An execution could only reach personal property. If a debtor did not wish to pay a debt, 
he could sell his crops privately in advance, or he could cover them and other personal property by chattel mortgages. Thurston as a lawyer knew the law. The law establishing the Territorial Government of Oregon provided that "all laws heretofore passed in said Territory [i.e., by the Provisional Government] making grants of land, or otherwise affecting or incumbering the title to lands, shall be, and are hereby declared to be, null and void."

Under the Donation Land Law a settler on public land had merely a possessory right which did not ripen into a title to the land until he had "resided upon and cultivated the same for four consecutive years." It was an estate upon condition. It was not subject to execution sale. If such a sale could have been made, under a law of the Territory of Oregon, a purchaser would take nothingnot even the possessory right of a settler. ${ }^{68}$ The settler was the only one who could complete the four years' residence and cultivation. In fact, it was a long time after the passage of the law before a land claim could be lawfully taken up. The settlers really held a kind of squatter's title until the Surveyor-General was ready to proceed or to receive applications for surveys. The first notifications were not filed until i 852 . Besides, the statute of limitations, for bringing suit on these debts, did not exceed six years.

The case of McLoughlin v. Hoover, I Oregon Reports, 32, was decided at the December term, I853, of the Supreme Court of the Territory of

\footnotetext{
${ }^{68}$ Hall v. Russell, ror $U . S ., 503$.
} 
Oregon. This case shows that Dr. McLoughlin did bring a suit shortly after September 29, 1852, the exact date not being given in the decision, against John Hoover to recover from Hoover a promissory note for $\$ 560$ dated October 2, 1845 , and payable one year after date. Hoover pleaded the Statute of Limitations. It was held by the Supreme Court of Oregon Territory that at no time under the Provisional or Territorial governments of Oregon was the statute of limitations to recover on notes and accounts for a longer period than six years. But by reason of amendments of the law, that the statute of limitations did not run a longer period than three years succeeding the act of September 29, 1849. The full six years from the time said note became due would end October 5 , I 853 , counting three days of grace, but under this decision the statute of limitations had run September 29,1852 , being less than five years from the time said note became due. The statute of limitations does not extinguish a debt. It merely stops the collection of it by law.

In this speech Thurston was compelled to admit that he had no proper foundation for the statement in his letter to Congress that Dr. McLoughlin had sent word to Fort Hall to turn the immigration to California. He said in this speech that the immigrants to Oregon "at a very early period, perhaps as early as 1842 or 1843 , were met with the tale that the Indians were hostile to the immigrants; that they would be cut off if they proceeded further on the Oregon trail; and that this story was told by the officer in charge of Fort Hall, as hav- 
ing been received from Vancouver, [the headquarters of Dr. McLoughlin] and that this same officer advised the emigrants to go to California." This statement is not borne out by the facts. That there was danger to the immigrants in coming to Oregon is shown by the intended massacre of the immigrants of 1843 , as set forth in this address and in the McLoughlin Document.

Thurston, in this speech, took up the Shortess petition and read numerous parts of it. He said in reference to the phrase that the petitioners hoped that Dr. McLoughlin never would own his land claim, that that is "just what the land bill provides for." Referring to the assertion in the Shortess petition that Dr. McLoughlin "says the land is his, and every person building without his permission is held as a trespasser," Thurston said: "What do you think of this, Mr. Speaker? An Englishman holding an American citizen a trespasser for settling on American soil, where the American Government had invited him! This, sir, was before the treaty [of 1846 ] and before the Provisional Government was formed, and when one American citizen had as good a right to settle there as another, and all a better right than Dr. McLoughlin. Yet this barefaced Jesuit has the effrontery to pretend he did not hold that claim by dint of threats." Thurston does not explain how the American Government invited the immigrants prior to 1847 to settle in Oregon. The truth is that the American settlers who left the East prior to 1849 went on their own initiative. They were neither invited nor helped nor protected by the Government, un- 
til after the establishment of the Territorial Government in I 849. Under the Conventions of jointoccupancy Dr. McLoughlin had the same rights, up to the Treaty of 1846 , as a British subject, that any citizen of the United States had - no more, no less. This, Thurston as a lawyer, knew.

After quoting further from the Shortess petition, Thurston said: "Now, Mr. Speaker, all this was before the Provisional Government was in operation-before the treaty, when no man had any right to meddle with the soil. Who can contemplate the helpless condition of these few and feeble American citizens, at that time and place, struggling for life, and for subsistence, thus kicked and buffeted round at the mercy of one of the most powerful corporations on earth, headed by a man whose intrigues must have furnished Eugene Sue with a clue to his 'Wandering Jew,' - who, I say, sir, can thus contemplate our flesh, and blood, and kindred, with their land, their houses, their all, thus posted up, and declared subject to any disposition this unfeeling man might make of them without shedding tears of pity for their distress.

Now, sir, just turn to my correspondence in letters one and two, where he tells you, if a man settled where the company did not allow him to, he paid the forfeiture with is life, or from necessity was compelled to yield. And here, again, the names of Wait and Thornton rise up before me, and while reading their laudations of McLoughlin, I can think of nothing but two Jews lauding Judas Iscariot.

"This petition is signed by many persons, many of whom I know, who are now living in Oregon. 
I can bear unqualified testimony to their character in society, to their honor and to their veracity. I undertake to say, that not a word is uttered in it but the truth, and it is susceptible of any reasonable proof. I know the gentleman who wrote the original, whom to know is to respect, to listen to, to believe. He is a gentleman of the highest standing in Oregon, of some twelve or fourteen years' residence, and who would be universally believed on any subject on which he would presume to speak. That gentleman informs me that every word of it is true to the letter. . . . If in the mouth of two or three witnesses all things are established, then surely sixty-five men are good evidence of the facts stated in the petition to which their names were attached, ard, then, you and the country can judge whether this man McLoughlin, by whom all the abuses here complained of were dictated, is entitled to receive gratuities of the American Government for such rascalities, or whether the people of Oregon owe him a debt of gratitude which they refuse to pay."

Thurston set forth the letter of Dr. McLoughlin to Robert Shortess, dated at Vancouver, April I3, 1843 , in which Dr. McLoughlin wrote: "I am informed that you have circulated a petition for signatures, complaining of me, and of the Hudson's Bay Company. I hope you will, in common fairness, give me a copy of the petition, with the names of those who signed it, that I may know what is said against us, and who those are who think they have cause of complaint against us." Thurston said: "The names must be given, and for what? I will not say whether as a sure guide to the toma- 
hawk of the Indian, or as a precursor to death by combined and grinding oppression-I leave this to the witnesses who have already spoken. But could you read in the records of heaven the deeds of this power in Oregon, while you would admire the consummate skill with which they were conducted, your whole moral nature would be shocked by the baseness of the design, and the means for their accomplishment."

Thurston in this speech, without giving names, gave excerpts from a number of letters he had received, sustaining his actions against Dr. McLoughlin in the Donation Land Bill. Shameful as Thurston's actions were against Dr. McLoughlin, Thurston had reason to believe that his actions were sustained and approved by leaders and members of the party which had elected him. Those who thus abetted Thurston in his misstatements and actions against Dr. McLoughlin were as culpable as Thurston was - they became his accessories. Some of these afterwards were ashamed of their actions against Dr. McLoughlin. Their repentances, although late, are commendable.

\section{DOCUMENT O}

Correspondence of S. R. Thurston, Nathaniel J. Wyeth, Robert C. Winthrop and Dr. John McLoughlin, published in the "Oregon Spectator:" April 3, I85I.

"Chicopee, Mass., Nov. i6, I850."

"Capt. Nath. J. Wyeth:

"My Dear Sir - You will excuse me, I am sure, 
when I assure you I am from Oregon, and her delegate to the Congress of the United States, for addressing you for a purpose of interest to the country to which I belong.

"I desire you to give me as correct a description as you can at this late period, of the manner in which you and your party, and your enterprise in Oregon, were treated by the Hudson's Bay Company, and particularly by Doc. John McLoughlin, then its Chief Factor. This Dr. McLoughlin has, since you left the country, rendered his name odious among the people of Oregon, by his endeavors to prevent the settlement of the country, and to cripple its growth.

"Now that he wants a few favors of our Government, he pretends that he has been the long tried friend of Americans and American enterprise west of the mountains. Your early reply will be highly appreciated, both for its information, and your relation to my country.

"I am, sir, yours very truly, "S. R. Thurston."

"Hon. Sam'1 R. Thurston:

"Cambridge, Nov. 21, I850."

"Dear Sir - Your favor of the r6th inst., was received on the rgth. The first time I visited the Columbia, in the autumn of 1832 , I reached Vancouver with a disorganized party of ten persons, the remnant of twenty-four who left the States. Wholly worn out and disheartened, we were received cordially, and liberally supplied, and there the party broke up. I returned to the States in the Spring of 1833 with one man. One of the party, Mr. John Ball, remained and planted wheat on 
the Willamette, a little above Camp du Sable, having been supplied with seed and implements from Vancouver, then under the charge of John McLoughlin, Esq., and this gentleman I believe to have been the first American who planted wheat in Oregon. I returned to the country in the autumn of 1834 , with a large party and more means, having on the way built Fort Hall, and there met a brig which $I$ sent around the Horn. In the winter and spring of 1835 , I planted wheat on the Willamette and on Wappatoo Island.

"The suffering and distressed of the early American visitors and settlers on the Columbia were always treated by Hudson's Bay Company's agents, and particularly so by John McLoughlin, Esq., with consideration and kindness, more particularly the Methodist Missionaries, whom I brought out in the autumn of 1834 . He supplied them with the means of transportation, seeds, implements of agriculture and building, cattle and food for a long time.

"I sincerely regret that the gentleman, as you state, has become odious to his neighbors in his old age.

"I am your ob't serv't,

"NATH. J. WYETh."

"Cambridge, Nov. 28, I850."

"Hon. Robert C. Winthrop:

"Dear Sir - I have received a letter from Sam'l $\mathrm{R}$. Thurston, of which the following is a portion: "I desire you to give me as correct a description as you can at this late period, of the manner in which you and your party, and your enterprise in 
Oregon, were treated by the Hudson's Bay Company west of the Rocky mountains, and particularly by Dr. John McLoughlin, then its Chief Factor. This Dr. McLoughlin has since you left the country, rendered his name odious among the people of Oregon, by his endeavors to prevent the settlement of the country and cripple its growth. Now that he wants a few favors of our Government, he pretends that he has been the long-tried friend of Americans and American enterprise west of the mountains.'

"I have written Mr. Thurston, in reply to the above extract, that myself and parties were kindly received, and were treated well in all respects by J. McLoughlin, Esq., and the officers of the Hudson's Bay Co.; but from the tenor of his letter, I have no confidence that my testimony will be presented before any committee to whom may be referred any subjects touching the interests of said John McLoughlin, Esq.

"The very honorable treatment received by me from Mr. McLoughlin during the years inclusive from 1832 to 1836 , during which time there were no other Americans on the Lower Columbia, except myself and parties, calls on me to state the facts.

"The purpose of this letter is to ask the favor of you to inform me what matter is pending, in which Mr. McLoughlin's interests are involved, and before whom, and if you will present a memorial from me on the matters stated in Mr. Thurston's letter as above.

"Respectfully and truly your ob't servant, "NATH. J. WYETH." 
"Washington, Dec. 28, I850."

"Dear Sir-I took the earliest opportunity to enquire of Mr. Thurston what there was pending before Congress or the Executive, in which Mr. McLoughlin's character or interest were concerned. He would tell me nothing, nor am I aware of anything.

"Respectfully your ob't serv't,

"To. N. J. Wyeth, Esq."

"R. C. Winthrop."

"John McLoughlin, Esq.:

"Dear Sir-On the igth of December, I850, I received a letter from Sam'l $R$. Thurston, delegate from Oregon, of which see copy No. I, and by same mail an Oregon newspaper containing a communication over your signature, the letter [latter], I think, addressed in your handwriting.

"From the tenor of Mr. Thurston's letter, I presumed he wanted my testimony for some purpose not friendly to yourself. I answered his letter as per copy No. 2, but doubting if my testimony, except it suited his views, would be presented, and being ignorant of his intentions, I wrote the Hon. R. C. Winthrop, late Speaker of the House of Representatives, and at present a member of the Senate of the United States, as per copy, [No. 3] and received from him a reply as per copy [No. 4].

"Should you wish such services as I can render in this part of the United States, I shall be pleased to give them in return for the many good things you did years since, and if my testimony as regards your efficient and friendly actions towards me and the other earliest Americans who settled in Oregon, 
will be of use in placing you before the Oregon people in the dignified position of a benefactor, it will be cheerfully rendered.

"I am, with much respect, yours truly,

"NATH. J. WYETH."

"Mr. Thurston writes to Mr. Wyeth, 'That Dr. McLoughlin has, since you left the country, rendered his name odious to the people of Oregon.' (That I have rendered my name odious to the people of Oregon, is what I do not know.) And 'By his endeavors to prevent the settlement of the country, and to cripple its growth.' I say I never endeavored to prevent the settlement of the country, or to cripple its growth, but the reverse. If the whole country had been my own private property, I could not have exerted myself more strenuously than I did to introduce civilization, and promote its settlement. 'Now that he wants a few favors of our Government, he pretends that he has been the long tried friend of Americans and American enterprise west of the mountains.' Mr. Wyeth states how I acted towards him and his companions, the first Americans that I saw on this side of the mountains. Those that came since, know if Mr. Thurston represents my conduct correctly or not. As to my wanting a few favors, I am not aware that I asked for any favors. I was invited by the promises held out in Linn's bill, to become an American citizen of this territory. I accepted the invitation and fulfilled the obligations in good faith, and after doing more, as I believe will be admitted, to settle the country and relieve the immigrants in their distresses, than any other 
man in it, part of my claim, which had been jumped, Mr. Thurston, the delegate from this territory, persuades Congress to donate Judge Bryant, and the remainder is reserved. I make no comment - the act speaks for itself, but merely observe, if I had no claim to Abernethy Island, why did Mr. Thurston get Congress to interfere, and what had Judge Bryant done for the territory to entitle him to the favor of our delegate? Mr. Thurston is exerting the influence of his official situation to get Congress to depart from its usual course, and to interfere on a point in dispute, and donate that island to Abernethy, his heirs and assigns, alias Judge Bryant, his heirs and assigns.

"Yours respectfully, "JNo. MCLoughlin."

With this correspondence was published the following letter from Doctor McLoughlin to the Editor of the Oregon Spectator: "I handed the following letters to the Editor of the Statesman, and he refused to publish them, unless as an advertisement." This last letter is quoted to show that the letters set forth in this Document $\mathrm{O}$ are authentic. The first number of the Oregon Statesman was published March 28, $185^{1 .}{ }^{69}$

\section{DOCUMENT P}

Letter from Rev. Vincent Snelling to Dr. John McLoughlin of March 9, I852.

The original of the following letter is now in the

${ }^{\circ 9}$ This correspondence was also published in full in the Western Star (published at Milwaukee, Oregon), in its issue of April ro, I851. 
possession of the Oregon Historical Society, from which this copy is made. Rev. Vincent Snelling was the first Baptist minister who came to Oregon.

"Oregon City, 9th March, 1852." "Mr. John McLoughlin, Esq.,

"Dear Sir:

"Having learned that you intend shortly to visit Washington City, and knowing that you have been misrepresented by our Delegate from this country,-and wishing as an honest man, and a friend to truth and justice, to contribute something toward the correction of those misrepresentations, I submit to your acceptance and disposal the following:

"I arrived in Oregon in the fall of 1844 and have been an observer of your treatment of and conduct to the American immigrants. I know that you have saved our people from suffering by hunger and I believe from savage cruelty also. I know you sent your boats to convey them down the Columbia river, free of charge, and that you also sent them provisions when they were in a state of starvation, and that you directed them to be distributed among the immigrants, to those that were destitute of money equally with those that had. Nor did your kindness stop there, as many of us lost nearly all we possessed by the time we arrived in the valley. You continued your favors by letting us have both food and raiment for the year, seed wheat, and charging no more than the same number of bushels the next harvest, plows and cattle to plow with. To conclude I do affirm that your conduct ever since I have known you has been such as 
to justify the opinion that you were friendly to the settlement of the country by Americans. I judge the tree [by] its fruit; you have done more for the American settlers than all the men that were in it, at that time.

"With sincere wishes that you may obtain your rights,

\author{
"I subscribe myself yours, \\ "VINCENT SNELLING, \\ "Ord. Minister Gospel, Baptist."
}

\title{
DOCUMENT Q
}

Excerpts from "The Hudson's Bay Company and Vancouver's Island" by James Edward Fitzgerald, published in London in I849; and excerpt from "Ten Years in Oregon" by Rev. Daniel Lee and Rev. J. H. Frost, published in New York in 1844.

In order to show some of the unjustifiable abuse of Dr. McLoughlin from British sources, I here insert an excerpt from pp. 13-18, inclusive, of "The Hudson's Bay Company and Vancouver's Island" by J. E. Fitzgerald. He says: "Dr. M'Loughlin was formerly an Agent in the North West Fur Company of Montreal; he was one of the most enterprising and active in conducting the war between that Association and the Hudson's Bay Company. In the year I $82 \mathrm{I}$, when the rival companies united, Dr. M'Loughlin became a factor of the Hudson's Bay Company. But his allegiance does not appear to have been disposed of along 
with his interests; and his sympathy with anything other than British, seems to have done justice to his birth and education, which were those of a French Canadian.

"This gentleman was appointed Governor of all the country west of the Rocky Mountains; and is accused, by those who have been in that country, of having uniformly encouraged the emigration of settlers from the United States, and of having discouraged that of British subjects.

"While the Company in this country were asserting that their settlements on the Columbia River were giving validity to the claim of Great Britain to the Oregon territory, it appears, that their chief officer on the spot was doing all in his power to facilitate the operations of those, whose whole object it was to annihilate that claim altogether. "There is one story told, about which it is right that the truth should be ascertained. It is said that a number of half-breeds from the Red River settlement were, in the year $184 \mathrm{I}$, induced by the Company's officers to undertake a journey entirely across the continent, with the object of becoming settlers on the Columbia River.

"It appears that a number went, but on arriving in the country, so far from finding any of the promised encouragement, the treatment they received from Dr. M'Loughlin was such, that, after having been nearly starved under the paternal care of that gentleman, they all went over to the American settlement on the Wallamette valley.

"These emigrants became citizens of the United States, and it is further said, were the first to 
memorialize Congress to extend the power of the United States over the Oregon territory.

"For the truth of these statements we do not of course vouch. But we do say they demand inquiry.

"Dr. M'Loughlin's policy was so manifestly American, that it is openly canvassed in a book written by Mr. Dunn, one of the servants of the Company, and written for the purpose of praising their system and policy.

"Sir Edward Belcher also alludes to this policy. He says, - 'Some few years since, the Company determined on forming settlements on the rich lands situated on the Wallamatte and other rivers, and for providing for their retired servants by allotting them farms, and further aiding them by supplies of cattle \&c. That on the Wallamatte was a field too inviting for missionary enthusiasm to overlook; but instead of selecting a British subject to afford them spiritual assistance, recourse was had to Americans - a course pregnant with evil consequences, and particularly in the political squabble pending, as will be seen by the result. No sooner had the American and his allies fairly squatted, - (which they deem taking possession of the country) than they invited their brethren to join them, and called on the American Government for laws and protection.'

"A great deal of importance is attached to the account given by Commodore Wilkes, U. S. N., of the operations of the Hudson's Bay Company on the north-west coast; and it is inferred that testimony, coming from such a quarter, is doubly in favour of the Company. 
"Nothing, indeed, can be higher than the terms in which Captain Wilkes speaks of the Hudson's Bay Company's chief factor, Dr. M'Loughlin, and of the welcome he met, and the hospitality he experienced during his stay upon the coast.

"Captain Wilkes was far too sensible and discriminating a man, not to see, plainly enough, whose game Dr. M'Loughlin was playing. But there is something strange, if we turn from the perusal of Captain Wilkes' narrative, and the description of the facilities which were ever afforded him, to the following passage from Sir Edward Belcher's voyage :

"The difference of the reception which a frigate of the United States Navy met with, from that which one of Her Majesty's ships experienced, is a most suspicious fact, as suggesting the animus of the Company's agents upon the north-west coast. Sir Edward Belcher says: 'The attention of the Chief to myself, and those immediately about me, particularly in sending down fresh supplies, previous to my arrival, I feel fully grateful for; but I cannot conceal my disappointment at the want of accommodation exhibited towards the crews of the vessels under my command, in a British possession.'

"We certainly were not distressed, nor was it imperatively necessary that fresh beef and vegetables should be supplied, or I should have made a formal demand. But as regarded those who might come after, and not improbably myself among the number, I inquired in direct terms what facilities Her Majesty's ships of war might expect, in 
the event of touching at this port for bullocks, flour, vegetables, \&c. I certainly was extremely surprised at the reply, that 'they were not in a condition to supply.'

The American policy of the Hudson's Bay Company would seem from the above facts, to be more than a matter of suspicion.

"It is very easy to say, these are idle tales; they are tales - but such tales, that Parliament ought to make a searching investigation into their truth. It is certain that Dr. McLoughlin has now left the Hudson's Bay Company, and has become nominally, what he seems to have been for years, really - an American citizen, living in the midst of an American population, which he collected around him, upon soil, to which he knew that his own country had, all along, laid claim."

Sir Edward Belcher's exploring expedition was at Fort Vancouver in August, I839. He insisted that the crews of his vessels should be supplied with fresh beef. Dr. McLoughlin was not then at Fort Vancouver. Probably he had not returned from his trip to England in $1838-9$. Mr. Douglas, who was in charge, refused Belcher's request because the supply of cattle was not sufficient for that purpose. Fresh beef was supplied to Sir Edward Belcher and his officers.

Commodore Wilkes and his exploring expedition were on the Oregon Coast in $184 \mathrm{r}$. He did not ask for his crews to be supplied with provisions. He was grateful for the kind treatment of himself, his officers and men, by Dr. McLoughlin and other officers of the Hudson's Bay Company. 
Sir Edward Belcher, it seems, was not grateful. ${ }^{70}$

In relation to the Red River immigrants, who arrived in $184 \mathrm{I}$, the statement of Fitzgerald is mostly untrue. These settlers came to Oregon in I 84 I under the auspices of the Hudson's Bay Company and settled on Nisqually Plains, near Puget Sound. These plains are almost sterile, being an enormous bed of very fine gravel mixed with some soil at the surface. It is easy to understand how these settlers were disappointed in living by themselves on the Nisqually Plains, when they could come to the Willamette Valley with its fertile soil and be near the settlers in the Willamette Valley. It must be borne in mind that when these Red River settlers went to the Willamette Valley, they were practically as much dependent on the Hudson's Bay Company and Dr. McLoughlin, as though they had stayed on the Nisqually Plains.

Rev. Daniel Lee and Rev. J. H. Frost wrote a book entitled "Ten Years in Oregon," which was printed in New York in 1844 . On page 216 of that work they say of these settlers from Red River: "They went to Nesqually, on Pugit's Sound; but, after spending a year, it was found that the land was of a very inferior quality, and that they could not subsist upon it. Thus, after having subjected themselves to many hardships, and privations, and losses, for almost two years, they had yet to remove to the Walamet Valley, as promising to remunerate them for their future toil, and make them forget the past. Accordingly most of them removed and settled in the Walamet in I $84 \mathrm{I}-2 . "$

${ }^{\text {io }}$ See Document F. 


\section{DOCUMENT R}

Note on authorship of "History of Oregon" in Bancroft's Works; and sources of information for this monograph.

Hubert Howe Bancroft obtained a fine collection of books and pamphlets relating to early Oregon and a great deal of other information before the "History of Oregon," in his Works, was written. A great many Oregon pioneers were personally interviewed and their statements reduced to writing. He also borrowed, on a promise to return, a great many private papers and other documents, including letters and copies of letters from the heirs of Dr. McLoughlin and from other Oregon pioneers and heirs of pioneers, which he has not yet returned, although he borrowed these papers and documents more than twenty years ago. Said "History of Oregon" is largely supplemented by foot-notes taken from this information obtained, or caused to be obtained by Bancroft. The defense of Dr. McLoughlin to the report of Capt. Warre and Lieut. Vavasour, was afterwards returned to Dr. McLoughlin by James Douglas, to whom it was sent by Sir George Simpson. It was among the papers loaned to Bancroft.

While Bancroft was a handy man in collecting materials, he wisely employed Frances Fuller Victor, Oregon's best and greatest historian, to write the "History of Oregon" for his Works. It was largely, if not wholly, written by her. This 
applies particularly to that part of the history up to and including the year I 850 . For years she had been a careful student of Oregon history. She had access to all the data collected by Bancroft.

In 1871 Mrs. Victor published "The River of the West" which sets forth many of the facts about Dr. McLoughlin, his land claim, and the actions of the missionaries and the conspirators against him, which are contained in this address and in the "History of Oregon" in Bancroft's Works. Volume one of the latter history was published in $\mathrm{I} 886$, and volume two was published in $\mathrm{I} 888$.

In writing this monograph on Dr. McLoughlin I have found The River of the $W$ est and Bancroft's History of Oregon of some use, especially where the information was taken from the documents so borrowed by Bancroft. But I have obtained most of my facts from original sources. Wherever it was possible I have consulted Oregon newspapers and books and pamphlets written by persons who took part in the events described, or which were written contemporaneous therewith, and letters written by pioneers.

The Oregon Historical Society has a number of original letters, files of early Oregon newspapers, and other documents relating to events in early Oregon. Many of these I have examined and taken copies of. In this I have been greatly aided by Mr. George H. Himes, for years the efficient Assistant Secretary of the Oregon Historical Society, and Secretary of the Oregon Pioneer Association. I have also obtained copies from two issues of the Oregon Spectator in the possession of the 
University of Oregon, through the courtesy of Prof. Frederic G. Young.

\section{DOCUMENT S}

Excerpts from opinions of contemporaries of Dr. McLoughlin.

In addition to opinions of Dr. McLoughlin set forth in the address, I here set forth excerpts from other opinions, given by some of his contemporaries. I have selected these out of many high opinions and eulogies upon Dr. McLoughlin.

Judge Matthew P. Deady, in an address before the Oregon Pioneer Association, in 1876 , said: ${ }^{71}$ "Dr. John McLoughlin was Chief Factor of the Company [Hudson's Bay Company] west of the Rocky mountains, from 1824 to 1845 , when he resigned the position and settled at Oregon City, where he died in 1857 , full of years and honor. Although, as an officer of the Company, his duty and interest required that he should prefer it to the American immigrant or missionary, yet at the call of humanity, he always forgot all special interests, and was ever ready to help and succor the needy and unfortunate of whatever creed or clime.

"Had he but turned his back upon the early missionary or settler and left them to shift for themselves, the occupation of the country by Americans would have been seriously retarded, and attended with much greater hardship and suf-

${ }^{i 1}$ Transactions of the Oregon Pioneer Association for 1876 , p. I8. 
fering than it was. For at least a quarter of a century McLoughlin was a grand and potent figure in the affairs of the Pacific slope. . . . But he has long since gone to his rest. Peace to his ashes! Yet the good deeds done in the body are a lasting monument to his memory, and shall in due time cause his name to be written in letters of gold in Oregon history."

Governor Peter H. Burnett, from whose "Recollections and Opinions of An Old Pioneer," I have already quoted, also said in that book (pp. 143, I44): "Dr. John McLoughlin was one of the greatest and most noble philanthropists I ever knew. He was a man of superior ability, just in all his dealings, and a faithful Christian. I never knew a man of the world who was more admirable. I never heard him utter a vicious sentiment, or applaud a wrongful act. His views and acts were formed upon the model of the Christian gentleman. He was a superior business man, and a profound judge of human nature. . . . In his position of Chief Factor of the Hudson's Bay Company he had grievous responsibilities imposed upon him. He stood between the absent directors and stockholders of the Company and the present suffering immigrants. He witnessed their sufferings; they did not. He was unjustly blamed by many of both parties. It was not the business of the Company to deal upon credit; and the manager of its affairs in Oregon was suddenly thrown into a new and very embarrassing position. How to act, so as to secure the approbation of the directors and stockholders in England, and at the 
same time not to disregard the most urgent calls of humanity, was indeed the great difficulty. No possible line of conduct could have escaped censure.

"To be placed in such a position was a misfortune which only a good man could bear in patience. I was assured by Mr. Frank Ermatinger, the manager of the Company's store at Oregon City, as well as by others, that Dr. McLoughlin had sustained a heavy individual loss by his charity to the immigrants. I knew enough myself to be certain that these statements were substantially true. Yet such was the humility of the Doctor that he never, to my knowledge, mentioned or alluded to any particular act of charity performed by him. I was intimate with him, and he never mentioned them to me."

Col. J. W. Nesmith, ${ }^{72}$ from whose address in I $876 \mathrm{I}$ have already quoted, in that address also said:"73 "Dr. John McLoughlin was a public benefactor, and the time will come when the people of Oregon will do themselves credit by erecting a statue to his memory. . . . Thus far detraction and abuse have been his principal rewards."

Hon. Willard H. Rees, a pioneer of 1844 , in his address before the Oregon Pioneer Association, in 1879 , said : "D4 "Dr. McLoughlin, as director of

${ }^{72}$ Col. J. W. Nesmith was a Captain of Oregon volunteers in the Cayuse Indian War of 1847 ; and also in the Rogue River Indian War of 1852 , and was Colonel of the First Regiment of Oregon Mounted Volunteers in the Yakima Indian War of 1855 . He was a United States Senator and also a Representative to Congress from Oregon.

${ }^{73}$ Transactions of the Oregon Pioneer Association for 1876, p. 58 .

"Transactions of the Oregon Pioneer Association for 1879 , pp. 29, 30. 
the affairs of the Hudson's Bay Company west of the Rocky mountains, had more power over the Indians of the whole Northwest Coast, which he judiciously exercised, than all other influences multiplied and combined. He was a great and just man, having in no instance deceived them, firm in maintaining the established rules regulating their intercourse, making their supplies, so far as the Company was concerned, strictly depend upon their own efforts and good conduct, always prompt to redress the slightest infraction of good faith. This sound undeviating policy made Dr. McLoughlin the most humane and successful manager of the native tribes this country has ever known, while the Indians both feared and respected him above all other men. . . . Dr. McLoughlin was no ordinary personage. Nature had written in her most legible hand preëminence in every lineament of his strong Scotch face, combining in a marked degree all the native dignity of an intellectual giant. He stood among his pioneer contemporaries like towering old [Mount] Hood amid the evergreen heights that surround his mountain home - a born leader of men. He would have achieved distinction in any of the higher pursuits of life. . . . His benevolent work was confined to no church, sect nor race of men, but was as broad as suffering humanity, never refusing to feed the hungry, clothe the naked, and provide for the sick and toilworn immigrants and needy settlers who called for assistance at his old Vancouver home. Many were the pioneer mothers and their little ones, whose hearts were made 
glad through his timely assistance, while destitute strangers, whom chance or misfortune had thrown upon these, then, wild inhospitable shores, were not permitted to suffer while he had power to relieve. Yet he was persecuted by men claiming the knowledge of a Christian experience, defamed by designing politicians, knowingly misrepresented in Washington as a British intriguer, until he was unjustly deprived of the greater part of his land claim. Thus, after a sorrowful experience of man's ingratitude to man, he died an honored American citizen."

J. Quinn Thornton was one of the early Oregon pioneers. He came to Oregon with the immigration of 1846 . At the meeting of the Oregon Pioneer Association in 1875, he furnished to that Association a history of the Provisional Government of Oregon. In this history, speaking of Dr. John McLoughlin, Thornton said:"75 "The late Dr. John McLoughlin resided at Fort Vancouver, and he was Chief Factor of the Hudson's Bay Company west of the Rocky Mountains. He was a great man, upon whom God had stamped a grandeur of character which few men possess and a nobility which the patent of no earthly sovereign can confer. . . As a Christian, he was a devout Roman Catholic, yet, nevertheless, catholic in the largest sense of that word. . . . He was a man of great goodness of heart, too wise to do a really foolish thing, too noble and magnanimous to condescend to meanness, and too forgiving to cherish resentments. The writer, during

\footnotetext{
${ }^{78}$ Transactions of the Oregon Pioneer Association for 1875, p. 51 .
} 
the last years of Dr. McLoughlin's life, being his professional adviser, had an opportunity such as no other man had, save his confessor, of learning and studying him; and as a result of the impressions, which daily intercourse of either a social or business nature made upon the writer's mind, he hesitates not to say, that old, white-headed John McLoughlin, when compared with other persons who have figured in the early history of Oregon, is in sublimity of character, a Mount Hood tow. ering above the foot hills into the regions of eternal snow and sunshine."

Col. J. K. Kelly was Lieutenant-Colonel of the First Regiment of Oregon Mounted Volunteers in the Yakima Indian War of 1855 . He was afterwards a United States Senator from Oregon, and Chief Justice of the Oregon State Supreme Court. In his address to the Oregon Pioneer Association in 1882, speaking of Dr. McLoughlin, Col. Kelly said:" "Just and generous as that law [Oregon Donation Land Law] was to the people of Oregon, yet there was one blot upon it. I refer to the provisions contained in the $1 \mathrm{Ith}$ section of the act by which the donation claim of Dr. John McLoughlin, known as the Oregon City claim, was taken from him and placed at the disposal of the Legislative Assembly to be sold and the proceeds applied to the endowment of an university. It was an act of injustice to one of the best friends and greatest benefactors which the early immigrants ever had. I do not propose to speak of the many estimable and noble qualities of Dr. Mc-

\footnotetext{
${ }^{20}$ Transactions of the Oregon Pioneer Association for 1882, p. 26.
} 
Loughlin here. They have been dwelt upon by others who have heretofore addressed the Pioneer Association, and especially by $\mathrm{Mr}$. Rees in 1879 . I concur in everything he said in praise of $\mathrm{Dr}$. McLoughlin.

"It was my good fortune to know him well during the last six years of his life, years which were embittered by what he considered an act of ingratitude after he had done so many acts of personal kindness to the early immigrants in their time of need. That Dr. McLoughlin was unjustly treated in this matter, few, if any, will deny. And I am very sure that a large majority of the people, in Oregon, at that time, condemned the act which took away his property, and tended to becloud his fame. And yet no act was ever done by the Territorial Government to assert its right to the Oregon City claim during the life of Dr. McLoughlin; and in 1862 , five years after his death, the State of Oregon confirmed the title to his devisees upon the payment of the merely nominal consideration of $\$ I, 000$ into the university fund. And so five years after he was laid in his grave an act of tardy justice was done at last to the memory of the grand old pioneer." It was largely through Col. Kelly's influence and actions that this act was passed in favor of Dr. McLoughlin's devisees.

Horace S. Lyman was a son of Rev. Horace Lyman, a Congregational minister who came to Oregon in I849, and who founded the First Congregational Church of Portland in June, $185 \mathrm{I}$. Horace S. Lyman grew up in Oregon and from his own knowledge, from personal association 
with pioneer missionaries and others, and from reading, he became well acquainted with the history of Oregon. He was the author of a "History of Oregon" published in 1903. His associate editors were Mr. Harvey W. Scott, Judge Charles B. Bellinger, and Prof. Frederic G. Young. In the fourth volume of this history, page $38 \mathrm{I}$, it is said: "Whether the justice of history, and the recognition of after times, when personal interests and partizan spites are dissipated, and a character like that of McLoughlin stands forth as one of the best ever produced under the British flag, and one of the best ever given to America, should be regarded as compensation for the injustice and sufferings of a life darkened in old age, may not be determined. Yet the historian must ever assert that a character worthy of perpetual commemoration and admiration, illuminating, by humanity and Christian doctrine, the dark chapters of wilderness life from the Atlantic to the Pacific, and setting a star of hope over the barracks of a mercenary trading company, is worth all personal sacrifice. It is of such acts that great history consists. Even to the Doctor himself, going down in old age and poverty, and doubting whether his family would have a support, and believing that he had better have been shot as a beast than to have so suffered, we may hope that it was but 'a light affliction, compared with the perpetual consciousness of a life of peace and good will sustained in a period menaced by war."

As I have said, my uncle, Daniel S. Holman, was one of the immigrants of 1843 . He was then 
about twenty-one years old. He will be eightyfive years old the fifteenth of November, 1907. $\mathrm{He}$ lives at McMinnville, Oregon, strong in mind and body. When I was honored by being selected to deliver the address, I wrote him asking for his opinion of Dr. John McLoughlin, for I knew his feelings. He wrote me August 7, 1905. In this letter he said: "I received yours requesting me to tell you of some of the kind acts of Doctor McLoughlin. It would take more time than I have to speak of all the very good things that he did, but I can say that he did all that was in his power to do to help the starving, wornout and poverty stricken [immigrants] that came to Oregon. For the first three or four years after I came if he had not helped us we could not have lived in Oregon. At the time we came he sent his boats to The Dalles, free of cost, to help all that could not help themselves to go down the river. He also sent food and clothing to the destitute and gave it to them. He also furnished seed grain to everyone who wanted, and waited for his pay until they raised wheat to pay. The fact is there never was a better man than he was. He did more than any other man did to settle Oregon. History says Doctor Whitman was the man who saved Oregon to the United States, but that is not true. It was Dr. John McLoughlin of the Hudson's Bay Company. So says every man that is a man, that came to Oregon up to 1849 . He furnished the entire immigration with food and clothing for the first year after we came. The people did not have money to live on and so he fed and clothed us all. 
Some never paid him but some did pay the good old man."

And he added a postscript to say that his wife thought he had not said enough about Dr. John McLoughlin. She has been my uncle's loving and faithful help-mate for more than fifty-nine years. She is a pioneer of 1846 . She, too, is still strong, mentally and physically. My uncle said in the postscript: "I can say that I am sure no man could have done better than he did to us all. In the fall of 1845 I went out to meet the immigrants and was gone from home six or eight weeks without a change of clothing. I got back to Vancouver where the Doctor then lived. I was as ragged as I could be. I went to his office and told him I wanted some clothing, but had no money. $\mathrm{He}$ gave me an order to his son to let me have whatever I wanted in the store. He treated others as he did me. In 1848 he let every one who wanted to go to the mines have all they needed, on time, to go to California. Some never paid him. Have you anyone in Portland that would help any and all such men off to the mines on such chances of getting their pay? I don't think there is such a man in Oregon, or any other place. You can't say too much in his praise."

Joseph Watt, a pioneer of 1844 , from whose "Recollections of Dr. John McLoughlin" I have already quoted, also said, in said Recollections: $:^{77}$ "The next I saw of the Doctor was in Oregon City, he having stayed at Fort Vancouver until all the 25-27.

"Transactions of the Oregon Pioneer Association for 1886, pp. 
immigrants for that year [ 1844$]$ had arrived. He was building a large flouring mill, at that time nearing its completion. He already had a sawmill in full blast, also was building a dwelling house, preparing to move to that place, which he did in the following spring. From that time to his death he was a prominent figure in Oregon City. Nothing pleased him better than to talk with the settlers, learn how they were getting along, their prospects, of their ability to live, and to help others. He was anxious that every one should be well and kept busy. He could not endure idleness or waste. Over-reaching, or, what we Americans call 'sharp practice,' he had no patience with whatever. As far as he was concerned all transactions were fair, straight-forward and honorable. Those who knew him best never thought of disputing his word or his declared intentions, although there were some high in authority who did this in after years, apparently for selfish motives; and through their representations, caused the U.S. Government to do an act of great injustice. But $I$ am proud to be able to say that all, or nearly all of the first settlers, did not endorse the action, and never rested until the wrong was adjusted as nearly as it was possible to do so. - . It appeared by common consent that he was practically the first governor of the great North Pacific Coast. No man ever fulfilled that trust better than Dr. John McLoughlin. He was always anxious over the Indian problem. No one understood the Indian character better than he did. All the Indians knew him as the great 'White 
Chief,' and believed whatever he said could be depended on; that he was not their enemy, but was strictly just with them in every thing;-could punish or reward, as he thought best, and no trouble grew out of it. But with the settlers the case was different. . . Dr. McLoughlin! Kind, large-hearted Dr. John McLoughlin! One of nature's noblemen, who never feared to do his duty to his God, his country, his fellow-men and himself, even in the wilderness. The pioneers of this great North-West feel that they owe Dr. John McLoughlin a debt of gratitude above all price, and that they and their posterity will cherish his memory by a suitable monument placed on the highest pinnacle of fame within the State of Oregon."

Archbishop F. N. Bianchet came to Oregon in 1838 as Vicar-General of the Roman Catholic Church in Oregon. He was consecrated as Archbishop in Quebec in 1845 . In his "Historical Sketches of the Catholic Church in Oregon" (published in 1878 ), from which I have already quoted, he also said of Dr. McLoughlin (pp. 8 and 9): "He was one of 'nature's noblemen' in every sphere of life. Of commanding presence, strict integrity, sound judgment, and correct principles of justice, no man was better qualified for the position he occupied as the father and friend of both the Indians and the whites who then jointly occupied the Pacific northwest. Dr. McLoughlin was the arbiter to whom both whites and Indians looked for the settlement of their differences, and the friend from whom they sought relief in all 
their difficulties. . . . Under the impartial supervision of this good and great man the business of the Hudson Bay Company prospered amazingly; he perpetuated peace between the Indians and the employes of the Company. . . . He also extended assistance to every immigrant whose necessities required it, and his good deeds have enshrined his name amidst the most honored of the pioneers of the Pacific Coast." And on page 7I Archbishop Blanchet said: "Dr. John McLoughlin was the father of the orphans and servants of the H. B. Co.; the father of the FrenchCanadian colonies of Cowlitz and Wallamette Valley; of all the American immigrants; and a great benefactor of the Catholic Church."

It will be remembered that Rev. Daniel Lee was a Methodist missionary, who came to Oregon in I834. He worked faithfully and earnestly for about ten years when he returned to the Eastern States. He continued in the ministry and died about I895. His son, Rev. William H. Lee, is the Pastor of the People's Mission Church at Colorado Springs. $\mathrm{He}$ was in Portland in 1905. In answer to the inquiry of Mr. G. H. Himes, Assistant Secretary of the Oregon Historical Society, Rev. William H. Lee wrote the following letter at his home, July 3I, I905, to Mr. Himes: "As the son of a pioneer Oregon Missionary I wish to add my tribute of respect to the memory of $\mathrm{Dr}$. John McLoughlin. For ro years my father Rev. Daniel Lee labored in missionary work in Oregon and during all these years John McLoughlin was his friend. When my Father and Mother were 
united in marriage it was within the hospitable walls of Ft. Vancouver and we treasure a marriage certificate signed by John McLoughlin as one of the witnesses. Many times have I heard my Father and Mother speak of the kindness of Dr. John McLoughlin. And one of the most pleasant memories of my recent visit to Portland was the privilege I had of stopping in Oregon City and placing some flowers on the grave of my Father and Mother's friend."

The well known writer, S. A. Clarke, who was an Oregon immigrant of 1850 , published a two volume work in 1903, entitled: "Pioneer Days of Oregon History." In this work (vol. I, pp. 214, 215) Mr. Clarke says of Dr. McLoughlin: "It was because of his loyalty to humanity and his kindness to Americans that he lost his high official station and was left almost heartbroken in his old age. We can afford to hold up in contrast those who profited by his bounty and left him to pay the bill; also those - be they Missionaries or who - that tried to rob him of his land claim, with the nobler minded man-John McLoughlin-who did so much and lost so much for humanity, and never expressed regret."

Mr. Clarke in this work (vol. I, p. 226) narrates the following incident, which was told to him by Dr. William C. McKay, who was a grandson of Mrs. Dr. John McLoughlin. It will be remembered that her first husband was Alexander McKay, who was killed in the capture of the Tonquin in I8I I. "In I 843 William Beagle and family reached Vancouver destitute, and he had the ty- 
phus fever. McLoughlin heard of it and told Dr. Barclay there was a sick and destitute family at the landing; to fix up a house for them, make them comfortable and attend to the sick.

"Dr. W. C. McKay had just returned from the States where he pursued medical studies. So the doctor invited him to assist in taking care of his patients. There was the mother and several children, who had all they needed for two months, until Beagle got better, when he went to Governor McLoughlin and asked what his bill was. 'Tut, tut, tut! bill, bill, bill! Take care of yourself, sir! That is the bill!" Beagle pleaded that even the doctor couldn't afford to take care of his family and treat them so long without pay. 'Tut, tut, tut,' was the reply. 'You do the best you can for some other man who is in trouble, and that will pay me.'

"He sent them up the Willamette, free of charge, sold them supplies that were necessiary until Beagle could earn money, and was finally paid for them in full. This is but one instance in the many where the kindness and generosity of Dr. McLoughlin was manifested toward Americans who reached Vancouver sick and impoverished and received his generous and kindly care." 
INDEX 



\section{INDEX}

ABERNETHY, General George, 65, 66, 109, 116, 122, 126, 134, I35, 187, 209, 2 I I, 223, 235, 240, $2+3$.

Abernethy Island, 102, 103, 107, 108, I10, 114, I16, I17, 122, 126, I $30,134,135,141,142,143,153$, $200,214,228,235,236,237,239$, $242,262$.

Academy, Wesleyan, Ir2 (see also Schools).

Acapulco (Mex.), I44.

Act, Organic, 67 ; of 1848,114 ; trading, 177 .

Adams, Thomas (an Indian), I 85 .

Agriculture, 85, 258.

Alaska, 19.

America, 38, I75, I80, 279; British, 32, 95 (see also Canada); North, 4I, 177, 178, 179; South, I89; a ship, 68.

Americans, 33, 34, 35, 36, 37, 3\$, 40, 42, 44, 45-52, 61, 62, 64, 66, $69,71,72,73,74,78,83,84,85$, $88,91,92,93,94,96,97$, го0, $102,124,127,129,133, x_{5}, I_{57}$, 1 67, 168, 170, 182, 199, 21 3, 220, $238,239,244,249,250,253,254$, $257,258,259,260,261,263,264$, $266,268,272,276,282,287,285$, 286.

Anderson, John, 2.05.

Applegate, Jesse, 67, 99, 108, I19, I20, I 50, 151, 224, 237.

Apples, 181 (see also Fruit).
Army, British, 23, 24, 91, 227.

Arnold, Benedict, 130, 230, 234 .

Arkansas (state), $22 \mathrm{I}$.

Arrendrill, C. T., 205.

Articles of Agreement, 224-226.

Astor, John Jacob, 20, 24.

Astoria, 19, 20, 27, 194, 197, 212.

Atlantic Ocean, 279.

Attorneys, 107, 118, 212, 218, 219, $225,247$.

BABCOCK, Dr. I. L., 2 ro.

Bailey, Dr.-, 2 ro.

Baker's Bay, 195.

Ball, John, 257.

Baltimore, 186 .

Bancroft, Hubert Howe, History of Oregon, cited, 92, 97, 99, ro7, IIO, II6, $211,227,229,270-272$.

Baptists, $133,238,263$.

Barclay, Dr.-, 76, 286.

Barlow Road, 9x.

Bates, James M., 205.

Battles, 23, 24 (see also Wars).

Beagle, William, 285.

Beaumont (Canadian parish), 23.

Beaver, Rev. Herbert, 34.

Beaver-skins, I9r.

Beef, 43, 44, 45, 195, 267.

Beers, Alanson, 65, 205.

Belcher, Sir Edward, 43, 44, 266, 267, 268, 269.

Bellamy, G. W., 205.

Bellinger, Judge Charles B., 279.

Bennet, V., 205.

Berry, William J., 135 . 
Blanchet, Archbishop Francis Norbert, I62; Historical Sketches, cited, $98,99,283,284$.

Blue Mountains, 33 .

Boats, 78, 184, 201, 232, 263, 280, (see also Ships).

Bonds, 208, 209, 217, 218, 225, 227.

Bonneville, Captain -, 33, 49, Ix7, 199.

Boone, Daniel, 83 .

Boston (Mass.), 48, 52, 186.

Bostons (name given to Americans), 72, 73, 74 .

Boundaries, of Oregon County, $x 9$, $20,2 x, 39,68,86$, ror, r29, r 3 r, $23 x, 232,233,236$.

Bowlin,-, 229.

Brallier, Henry, letter by, $x 96, x 97$.

Bread, 59.

Brewer, H. B., 205.

Bribery, 143.

Bridges, J. C., 205.

British, 35, 39, 40, 64, 67, 68, 92, 97,157, I $65, x 66,215,2$ I 6,23 , 232, 239.

Brooks, Wm. (an Indian), 185.

Broughtan, Lieut. -, 28.

Brown,-, 221.

Brown, G., 205.

Brown, Jeffrey, 205.

Brown, J. Henry, Political history of Oregon, cited, 66, II9, 209.

Brown, William, 205.

Brum, William, 205.

Bryant, Judge IW. P., I22, 130, $x_{33}, 1_{34}, x_{35}, x_{42}, x_{4} 8, x_{52}, 228$, $229,235,239,240,24 \mathrm{I}, 243,249$, 262.

Bryce,-, The remarkable history of the Hudson's Bay Company, cited, $18 \mathbf{I}$.

Buddha, 146 .

Burgoyne, General John, 23.

Burnett, Peter H., 70, 73, 75, 76, 77, I 20, I2I, I $51,273,274$.

Burns, Hugh, 210.
Butler, 59.

CALCUTTA (India), 48 .

California, 19, 25, 37, 44, 45, 50, $51,52,64,69,76,123,124,138$, r 99, 248, 252, 253, 28 r.

California Bill, 132, 234 .

Cambridge (Mass.), 45, 258.

Campbell, H., 205.

Campbell, J. J., 205.

Camp du Sable, 258.

Canada, Dominion of, 20, 22, 23, 24, xII, x13, 186; Upper, 38, 39.

Canadians, 79, 133, $189,190,238$;

French, 4x-45, 46, 6I, 98, 99, $265,284$.

Canal, 201.

Cannon, 29.

Canoes, 54, 72, 197.

Cape Horn, 258.

Carolinas, 84 .

Cartee, L. F., 153.

Carter, David, 205.

Cascades, 70, 71, 76, 197; Mountains, 79, 91. See also Rapids.

Cason, F. C., 153.

Casualties, 70.

Cathlamet, 195 .

Catholics, 22, 98, 99, 100, $x_{33}, 147$, $x_{5} 1, x_{57}, x_{67} x_{71}, x_{89}, x_{90}$ x 91 , I $92,238,276$.

Cattle, 28, 37, 43, 44, 45, 57, 66, $75,76,77,78,87,117,183,194$, 199, 232, 258, 263, 266, 268.

Cayuse (Indian tribe), 37, 40, 6r, $74,88, \quad 145,274$ (see also Wars).

Champoeg (Ore.), 65, 69 (see also the following).

Champooing, 192.

Chance, William, 2 r2.

Charles II (king of Great Britain), $2 \mathbf{r}$.

Charters, 21, 95, 194 (see also Grants).

Chemekete, (Ore.), Ix5. 
Chicopee (Mass.), 256.

Churches, 99, 238; Catholic, I 57, I67, I7I, 283; English, I67; Methodist, 109. See also Missionaries and kindred topies.

Clackamas County (Ore.), Irs. 124.

Clackamas Falls, 236.

Clackamas Female Protestant Seminary, $133,238$.

Clackamas River, ro6, I07, III, I20, 237.

Clark, George Rogers, 83.

Clarke,-, I9r.

Clarke, S. A., Pioneer days, cited, $285,286$.

Clayoquot Sound, 24.

Coggswell, William (artist), I62.

Colonies, American, 20.

Colorado Springs (Col.), 284 .

Columbia River, 20, 21, 26, 27, 28, $30,32,33,34,35,36,38,42,45$, $46,47,49,51,59,67,70,71,79$, $80,85,89,90,100,103,136,140$, 154, 195, 198, 199, 201, 203, 204, $216,222,230,232 ; 245,257,258$, $259,263,265$.

Commissioner of Indian Affairs, II 8.

Compo, Charles, 205.

Comyns,-, 217.

Confiscations, 159 .

Confucius, 146 .

Congregationalists, $133,147,238$, 278.

Congress, 21, 65, 104, 105, I1 6, 121, 1 23, I29, I30, 132, I 35, I36, I 37, $I_{3} 8,139,142,143,144,145,146$, 149, I $50, I_{52}$ I $53,1_{54}, 1_{55}, 203$, $204,210,215,217,220,232,243$, $244,246,248,252,257,260,262$, 266, 274 .

Congressional Globe, cited, 129, 229, $234,247$.

Constitution, 64, I21, $215,217,250$. Conventions, 21, 32, ror, 113 , 129,

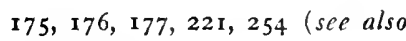
Treaties).

Cook, Aaron, 205.

Coombs, E. N., 205.

Copeland, A., 205.

Corn, 2 I3.

Coursen,-, 22 I.

Courts, 38, 39, 109, I I 3, I I 5, I I6, I21, 128, 142, 198, 21 5, 221, 222, $223,225,228,229,240,249,250$, 25 I, 252.

Cowenia,-, 128 .

Cowlitz, 284 .

Crawford, Medorum, 69, 205.

Creeks, 184 .

Curry, George L., 243, 244, 249.

DALLES (Indians), 72, 73 .

Dartmouth College, 74 .

Davis, George, 205.

Davis, S., 205.

Deady, Judge Matthew P., 128, I62, 272, 273 .

Debt, collection of, 252 .

Deeds, land, II5, 118, 203, 205, $206-208,217,225$.

De Haven,-, 128 .

Donation Land Law, 101, 102, 103, I05, I Iо, III, 123, I24, 128, I29, I 37, 140-143, I45, I49, I 50, I 52, I 54, I 57, I 59, I60, I6I, I64, 247, $248,251,256$.

Douglas, James, $39,43,44,67,75$, I 9I, 195, 226, 227, 268, 270.

Dryad, (a ship), $5 \mathbf{I}$.

Dunn,-, History of the Oregon Territory, cited, 29, 36, 37, 266.

EDMUNDS, John, 205.

Edwards, 一, 183.

Edwards, P. L. (teacher), 55, 73.

Ekin, Richard H., 205.

Elections, 244.

Elijah, an Indian, 37.

Ellice, E., 178 .

England, 20, 25, 32, 36, 43, 103, I13, I25, I34, I67, 177, 239, 273. 
English, 38, 125, 133, 182, 238, 253, (see also British, England, and Great Britain).

English Church, 98, 19 I.

Epidemics, 27, 60 .

Epitaph, 158.

Epps, Captain -, 24.

Ermatinger, Frank, 274.

Evans, Elwood, History of Pacific Northwest, cited, I Iо, I I6, 2 I I.

Executions, 38, 40.

Expeditions, $43,45-52,54,76,77$. 195, 227, 268.

Exports, 28, 29.

\section{FAIRFIELD (Ore.), 99.}

Farmers, 199, 234.

Farms, 28, 4r, 42, 8 1, 181, 194, 199, $213,215,217,266$.

Farnham, Thomas J. (traveler), 30.

Faulitz Plains, r91.

Figueroa,-, (governor of California), 5 r.

Fillmore, Millard, I4r, 249.

Fitzgerald, James Edward, The IIudson's Bay Company, cited, 264-268, 269.

Flatheads (Indian tribe), 55, 122. Flour, 117, 122 (see also Wheat).

Force, James, 205.

Forest Creek (Ore.), 243.

Forts, 20, 21, 24, 27, 28, 32, 33, 34, 35.

Fowl, 43.

Fraser, Angelique, mother of McLoughlin, 23.

Fraser, Malcolm, 23.

Fraser, Samuel, M. D., 23.

Fraser, General -, 23.

Fraser Highlanders, 23.

Fremont, Col. John C., 77, 78, 227, 233.

French, 38, 182, 245 (see also Canadians, French).

French Prairie (Ore.), 56, 102.
Freshets, I84.

Frost, Rev. J. H., 188, 269.

Fruit, 28.

Funds, misappropriation of, 187 .

Furs, 20, 26, 29, 32, 35, 36, 42, 52.

Furtrade, 32, 33, 177, 178, 202.

Furtraders, 24, 31, 33, 34, 35, 37, 49 (see also Trade and commerce).

GALE, Joseph, 65 .

Garden, 203.

Gary, Rev. George, 63, 109, 110, 222.

Gay, George, 2 ro.

George (Fort), 20, 21, 27, 28.

Germany, 26.

Ghent, 20, 2 r.

Gibbs, Joseph, 205.

Gifts, 57, 59, 71, 73, 82, 138, 139, I+1, 165 .

Gilpin, Major W., 226, 227.

Girtman, Daniel, 205.

Gladstone Park, ro6, III.

Goats, 28.

Gordon, Captain -, 68, 91 .

Governor's Island. See Abernethy Island.

Grain, 28 (see also Wheat).

Grants, I78, 179, I80, 205 (see also Charters).

Gray, W. H., 54; History of Oregon, cited, 66, 119, 205, 209, 2 ro.

Great Britain, 19, 20, 21, 32, 33, $34,39,64,65,66,67,68,71,90$, 93. 95, 100, 101, 104, 112, 128, I4 I, 142, I 56, 157, I64, 775,176 , $221,250,265$. (See also England).

Green River, 53.

Greenhow -, History of Oregon and California, cited, Iso.

Gregory XVI (pope), I6r.

Griffin, J. S., 123.

Griffith,一, I91.

Grover, Gov. L. F., 158, 159. 
HALL, - 25 I.

Hall (Fort), 46, 47, 69, 129, 131, $229,231,233,252,258$.

Hannah,-, 128.

Harvey, Daniel, 25, 160.

Harvey, James W. McLoughlin, (grandson of Dr. J. McLoughlin), 25,63 .

Hastings,-, 203, 205, 207, 209.

Hathaway, Felix, 114, I15, I34, 205, 235, 236, 239.

Hauxhurst, W., 205.

Hawaiian Islands, 28, 51, 212, 213, 222.

Hess, Joseph, 79.

Hill, David, 65.

Hill, Tom (a Shawnee Indian), 74.

Himes, George H., 272, 284.

Hines, Rev. Gustavus, 48, 205, 223; History of Oregon, cited, $57,59,222$.

Hines, Rev. H. K., D. D., 48, 55, I66-169, 187 ; Missionary history, cited, 55, 56, 58, 59, 60, 61, 62, 65, 106, 110, 111, 112, 113, $185,186$.

Hoaikaika (ship), 222, 223.

Hofstatter, John, 205.

Hogs, 28, 75, 76 .

Holman, Daniel S., 70, 279-28r.

Holman, Frederick V., preface, 15-17; Dr. John McLoughlin, 19-172.

Holman, J., 205.

Holman, James D. (the author's father), $138,241$.

Holman, John (grandfather of the author), 70 .

Holman, Joseph, 113, I14.

Holman, Woodford C., 138 .

Honolulu (Hawaii), 222.

Hoover, John, 25I, 252.

Horregon, Jer., 205.

Horses, 28, 51, 69, 77,87, 159, 183, 194.
Howard,-, 221.

Howard, John, 205.

Howison, Lieut. Neil M., 135, 136.

Hubbard, T. J., 205.

Hudson Bay, 184.

Hudson's Bay Company, 20, 21, $22,24,25,26,27,29,32,33,34$, $35,36,37,38,39,42,43,44,45$, $46,47,49,50,51,53,54,56,57$, $58,62,66,67,68,69,71,73,74$, $76,77,79,81,86,90,91,93,94$, $95,97,102,104,110,115,116$, I1 $7,118,120,123,124,125,129$, 130, 131, 133, 134, 135, 139, 150, $155,156,157,162,167,168,176$, $177,178,179,185,191,192,194$, 195, 196, 197, 199, 200, 201, 202, 204, 210, 212, 216, 220, 229, 230, $231,232,238,239,241,242,247$, $248,255,257,258,259,264,266$, $267,268,269,272,273,274,275$, 280,284 .

Hudspath,-, 237.

Humason, Orlando, 153.

Hunters, I91.

IDAHO, $19,46,54$.

Illinois (state), $\mathbf{I}_{3}$.

Immigrants, and immigration to Uregon, 15, 41, 6r, 62, 64, 69$90,91,92,93,94,96$, 100, 105, $116,129,132,136,140,148,150$, $151,165,169,196,197,230,232$, $233,248,252,253,26 \mathrm{r}, 263,265$, $269,272,273,279,280,281,284$.

Independence (Mo.), 70, 87 .

Indians, 24, 26, 27, 32, 35-4I, 49, $54,55,60,61,62,63,71,72,73$, $74,87,88,92,95$, 100, 103, 107, $112,124,132,141,156,163,171$, $177,178,179,180,182,185,186$, r88, 192, 193, r96, 202, 230, 235, $238,252,256,274,275,282,283$, 284 .

Ireland, 22, 176, 250.

Irish, 133, 151, 182, 238. 
Iroquois (Indians), 73.

Ithaca (N. Y.), 53 .

Ivory, 63 .

JACKSON,-(furtrader), 33.

Jackson, B. B., 153.

Japanese, 182 .

Jesuitism, 234.

Jesuits, 61 .

Jews, 146.

Johnson, W., 205.

Judges, I 34, 162, 239, 244, 245, 250.

Judson, L. H., 205.

KAMOURASKA (parish in Canada), 22.

Kaministiquia River, 24.

Kelley, Hall J., 50, 51, $5^{2}$.

Kelly, Col. -, 278.

Kentucky (state), 83 .

Kilbourn, Captain W. K., 237.

Kincaid, H. R., Biennial Report, of 1899 , cited, 228.

Klakamus Plains, 204.

Klakamus River, 200 (see also Clackamas).

Kone,-, I87, 188.

LADD \& CO., 204.

La Framboise, Michel, 195, 197. Lambert, Captain -, 182 .

Lancaster, Columbus, $123,245$.

Land Claims, 68, 80, 88, 99, ror$114,118,119,122,123,124,125$, $127,129,132,136,137,138,139$, $140,141,142,143,144,146,152$, r $53,154,155,159,160,200,202$, $205,214,218,220,222,223,225$, $227,228,229,232,234,235,236$, $237,238,240,241,242,243,245$, $251,253,262,272,277,278,285$.

Land laws, I19, 120, 123 (see also Donation Land Law).

Lane, Gen. Joseph, 65, 235, 240, $242,248$.

Lapwai (Idaho), 54 .
Lausanne (a ship), $48,59,61,63$, I03, I05, II3, I15, 186.

Lawson, J., 205.

Lawyer, 254.

LeBreton, George W., 205.

Lee, Rev. Daniel (missionary), 55, $59,73,102,113,114,181,183$, $264,269,284$.

Lee, Rev. Jason (missionary), 50, $54,55,56,57,58,59,62,65,66$, 73, 102, 106, I10, III, I12, 167, $180-185,186,187,188,189,210$, $212,214,219,222,223,235,236$, 237.

Lee, Rev. William H. (son of Daniel), opinion of McLoughlin, $284,285$.

Leslie, Rev. David, 58, 108, Iro, 224, 226, 227.

Lewis, Jr., S., 205.

Lewis, Reuben, 205.

Lewis and Clark Exposition, 16.

Lewiston (Idaho), 54.

Linn Bill, ro4, $1 \mathrm{rr}, 26 \mathrm{r}$.

Linn, Senator -, 104, IIr.

Linnton (Ore.), 75 .

London, 21, 29, 36, 43, 46, 59, 63, 96, I 12, 168, 175 .

Los Angeles (Cal.), 25.

Lovejoy, A. Lawrence, 122, 226; letter by, 218, 219.

Lucier, Etienne, ro2, 103.

Lumber, 28, I17, 122 (see also Timber).

Lyman, Horace, 278.

Lyman, Rev. Horace S., History of Oregon, 278, 279.

Lytle,一, 22 r.

McCARver, General -, 73.

McDougal, Duncan, 20.

McGillivray, S., 178 .

McGillivray, W., 178 .

McGruder, Theodore, 240.

McKarty, William, 205.

Mckay,-, I8I. 
McKay, Alexander, 24, 285.

McKay, Dr. William C., 285.

McLoughlin, David (brother of Dr. McL.), 23, 24.

McLoughlin, David (son of Dr. McL.), 24, 25, 160.

McLoughlin, Eliza (daughter of Dr. J. McL.), 24.

McLoughlin, Eloisa (daughter of Dr. McL.), 24, 25, 160 .

McLoughlin, John (father of following), 22.

McLoughlin, Dr. John: revered in Oregon, Is; McLoughlin Day, 16; life, 19-172; illustrative documents on, 175-286; genealogy and family, 22-25; and the Oregon Country, 25-27; treatment of Indians, $35-41$; letters, etc. by, 57, 149-1 52, 205, 206, 229-243 (see also McLoughlin Document, and Deeds); kindness and humanity of, $34,36,37,45-48,56,57,59$, $72,73,75-83,89,100,101,106$, $163,164,167-172,181,182,184$, I 90, 197, 257-259, 272-286; appellations, 91, 161, 168, 171, 282, 283 ; persecuted, 122, 123, 152158 ; his land claims (see Land Claims); naturalized, r20-122 ; answer to Thurston, 130-8 35 .

McLoughlin, John (son of Dr. McL.), 24.

McLoughlin, Mrs. Dr. John, 285.

McLoughlin Day, 16, 196.

McLoughlin Document, cited, 4r, $44,48,55,71,72,82,83,103$, $155,156,253$.

McMinnville (Ore.), 280.

McNeil, Captain -, 239.

Magruder, Theodore, 122.

Marechell,-, 196, 197.

Marion County (Ore.), roz.

Martin, -, Hudson Bay Territories, cited, 180, 18r.
Massachusetts (state), 45, Ir2.

Mazatlan (Mex.), 222.

May Dacre (a ship), 47, 57 .

Meek, Joseph L., 123.

Melons, I8r.

Memphregog (Lake), II2, II3.

Methodists, I13, 116, I19, 133, 147, 238 (see also Missionaries, and Missions).

Mexican Government, 52.

Mexico, 222.

Mills, 28, 79, 103, I1 5, II6, II8, 124, 125, 126, 127, 132, 134, 154, 193, 199, 200, 201, 214, 234, 240, 282.

Milner, Dr. -, 99.

Milwaukee (Ore.), I $+4,262$.

Mines, 123, $28 \mathrm{r}$.

Minto, John, 37, 79, 164 .

Mirabel (Cal.), 25.

Missionaries, 38, 50, 56, 81, 100, 102, I 12, 147, 148, 166, 167, 169, 180-185, 186, 190, 191, 192, 236, 272, 279, 285; Catholic, 98, 100; Congregational, 98; Methodist, $52,54-63,65,88,98,103,104$ $105,109,110,111,115,126,147$, $148,187,188,212,224,258,284$; Presbyterian, 52-54, 98 (see also Missions).

Missionary Board, Report to, I85189, 222.

Mission Church, 284.

Mission Party, 123, 138, 144, 145.

Missions (Catholic), 192.

Missions (Methodist), 64, 67, 103, 105, 106, 108, 109, I10, III, II4, I $5,116,120,123,124,127,132$, $146,185,187,192,193,202,210$, 2 r4 $222,223,226,227,228,234$, $235,245$.

Mississippi River, 84.

Missouri (state), 58, 70, 84, 87, 229.

Modeste (ship), 68.

Moffitt, J. W., 153. 
Montana (state), I9, 20.

Monopolies, 44, I9I, 216, 220.

Montreal, 20, 22, 264.

Morrison, J. L., 205.

Moss, S. W., 205.

Mount Hood, I71, 275, 277.

Mt. McLoughlin, r7o, I7r.

Mt. Pitt, 170.

Murders, 35, 40, 74 .

Myrick, Mrs. Josiah, 25, 158.

NESMITH, Col. J. W., 4r, 7o, $71,75,123,274$.

Nesqually, 269.

Nevada (state), 19.

New England, 85, roo.

New England conference, 112.

New York (city), 63, 185, 186, 222.

New York Herald, cited, 75 .

Nisqually Plains, 269.

North Fork, 184.

North Pacific Coast, 282.

Northwest Coast, 13I, 20I, 23I, 275.

Northwest Fur Company, 20, 2r, 22, 24, 95, 176, 177, 178, 264.

Nunnery, 238.

Nutall, - (botanist), 49, 50.

Nye, Chauncey, 153.

OAK, 192.

Ohio (state), I $\mathbf{3}$.

O'Neil, James A., 205.

O'Neill,-, 194.

Oregon (country, territory, and state), 1 5, 16, 17, 19, 20, 21, 22, $25,27,29,30,32,33,34,35,36$, 37, 39, 40, 4I, 42, 44, 48, 49, 5I, $52,53,54,56,57,58,59,6 \mathrm{I}$, $62,63,64-68,69,70,71,77,79$, $81,83,84,85,86,88,91,92,94$, $95,96,100,101,103,104,109$, I10, I12, I13, I14, I15, I19, I21, $122,123,124,126,129,131,132$, $135,137,138,139,140,142,143$, $144,145,148,1_{53}, 1_{54}, 156,158$,
I60, I6I, I62, I64, I65, I66, I67, I 68, I69, I70, I7 1, 172, г76, I 85, 187, 188, 190, 196, 197, 198, 199, 201, 202, 204, 205, 206, 207, 208, 209, 211, 212, 21 3, 218, 221, 222, 223, 224, 227, 228, 229, 23 I, 233, $235,238,240,250,25 \mathrm{I}, 252,254$, $255,256,257,258,259,260,26 \mathrm{I}$, 262, 263,265, 266, 268, 269, 270, 27 I, 273, 274, 276, 277, 278, 280, $281,283,284$.

Oregon (ship), 195 .

Oregon Bill, 223, 233 (see also Donation Land Law).

Oregon City (Ore.), $42,59,66$, $68,69,70,80,82,87,91,96$, ror, 102, 103, 106, 107, 108, I10, II I, I 15, I $6,118,121,122,123,124$, I25, 127, 132, 1 35, 136, 137, I38, I39, I40, I4I, I42, I 54, I 55, 157, I 59, 202, 205, 206, 207, 208, 2 I I, 212, 21 3, 21 9, 220, 222, $224,225,226,227,234,237,240$, $2+1,242,243,244,245,247,272$, 274, 278, 28 r, 282, 285.

Oregon City Claim, 124 (see also Land claims).

Oregon Donation Law, 19 (sce also Donation Land Law).

Oregon Historical Society, 16, 68, $75,16 \mathrm{r}, 180,187,212,218,223$, 224, 226, 263, 28.

Oregon House Journal, cited, I53, I6o.

Oregonian, cited, 196.

Oregon Land Bill, $\mathrm{I}_{32}$ (see also Donation Land Law).

Oregon Legislature, $67,133,152$, I $53, \mathbf{1 5 4}$, I60, I6I, I63, I64, I70, 171, 277.

Oregon Milling Company, ro8, $I_{4}, I_{1}, I_{17}, I_{1} 8,1_{22}, I_{27}, x_{30}$ 200, 201.

Oregon Pioneer Association, 4I, 6r, $69,71,75,79,82,162,163,164$, 165, 212,272, 274, 276, 277, 281. 
Uregon Provisional Government, $39,40,64-68,70,88,92,93$, rox, 109, 11 5, 119, 120, 138, 151, 237, 249, 251, 252, 253, 254, 276.

Oregon Reports, cited, 251.

Oregon Senate Journal, cited, r6o. Oregon Spectator, cited, 87,124 , 130, 135, 137, 138, 139, 145, 229, 243, 246, 256, 262, 272.

Oregon Statesman, cited, 262.

Oregon Supreme Court, I28.

Oregon Territorial Government, $19,65,138$.

Oxen, 44, 57, 76, 87, 88, 168, 183 (see also Cattle).

PACIFIC Coast and slope, I5, 273, 284.

Pacific Fur Company, 20, 24.

Pacific Ocean, 19, 45, 186, 279.

Pancott, Theodore, 205.

Paris (France), 24.

Park, Captain -, 68, 91 .

Parker, Rev. Samuel (Missionary), 53 .

Parliament, 32, 38, 177, 268.

Parrish, J. L., 62, 205.

Patents, 215.

Pawnee Mission, 58.

Peacock (ship), 194, 196.

Peel, Lieut. Wm., 68, 91.

Peel, Sir Robert, 68.

Penalties, 35-4I, 42.

Pendleton (Ore.), 48, 166.

Pennoyer, Governor Sylvester, 165. Peopeomoxmox (Indian Chief), 37 .

Perkins, Rev. H. K. W., 2 ro.

Pfeiffer, W. A., 205.

Philadelphia (Penn.), I86, I90.

Pillar Rock, 38.

Pine, 192.

Pineries, 112.

Pioneers, 15, 37, 67, 71, 77, 86, 91, ror, $1_{37}, 1_{3} 8,1_{39}, 1_{40}, 1_{4} 8,1_{50}$, I $58, \mathbf{1}_{3}, \mathbf{1} 64, \mathbf{1} 65, \mathbf{1}_{70}, \mathbf{I}_{7} \mathbf{1}, \mathbf{1}_{72}$, I86, 270, 275, 281, 283, 284 .
Pittman, Anna Maria, 58.

Platte River, 184.

Plows, 263.

Polk (County), 243.

Polk, James K., 21, 87, roo.

Pomeroy, Walter, 206, 2 ro.

Porpoise (ship), 195.

Portage, 236.

Porter, J. M. (Secretary of War), 136.

Portland (Ore.), 16, 17, 25, 75, I 58, I 59, 162, 196, 209, 278, 281, $284,285$.

Portland General Electric Company, 102.

Potatoes, 28, 213.

Prairies, r93.

Presbyterians, I33, 146, 238.

Prices, 33, 43, 44, 45, 46, 49, 77, Ir 8, 201 .

Priests, Catholic, 22, 6I, 189, 191.

Protestants, roo, 133, 146, 147, 190, 238.

Puget's Island, r95.

Puget Sound, 68, 190, 269.

QUEBEC (city), 22, 283.

RACCOON (British sloop-ofwar), 20.

Rae, William Glen, 24, 25, 69.

Rafts, 70 (see also Ships).

Rapids, 70, 102, 103, I14, I19, 136, I $91,200,201,202,213,224,235$, 236, 242.

Raymond, W. W., 224, 226.

Red River Settlement, 265, 269.

Rees, Hon. Willard H., 274, 278 ; opinion of McLoughlin, 274-276.

Regiments, 23, 274.

Rekener, J., 205.

Remick, William C., 204, 205.

Revolution, Cromwellian, roo.

Richmond, Dr. -, 188.

Ricord, John (attorney), 107, 212$218,220,222,223$. 
Rivière du Loup (a parish), 22. Robb, J. R., 205.

Robertson, James, 83 .

Rocky Mountains, 19, 20, 49, 53, $94,97,124,162,176,177,183$, $185,200,210,259,261,265,272$, 275, 276 (see also Stony Mountains).

Rogue River Indians, $\mathbf{2 7 4}$.

Rome (Italy), 16I.

Roosevelt, Theodore, Winning of the West, cited, 84 .

Roy, Charles, 205.

Russell,-, 251.

Russians, 201.

ST. GREGORY the Great, Knight of, 161 .

St. Lawrence River, 22.

Salem (Ore.), 56, III, I13, II5, I19, 138, 159, 163.

Salmon, $36,43,202$.

Sand Island, 35 .

Sandwich Islands, 29, 187, 189, 204, 220.

San Francisco (Cal.), 25, 69, 135.

Saratoga, battle of, 23 .

Savages, 26 (see also Indians).

Sawyer, 一, I28.

Schoolhouses, 30.

Schools, 98, 99, 1 33, 192, 238 (see also Seminary).

Scotch, 182, r9o.

Scotland, 23, 24.

Scott, Harvey W, 279.

Seaside, 196, 197.

Seminary, 238 (see also Schools).

Senate Document, 209.

Senators, 70, 158, 274 .

Sevier, John, 83.

Seymour, Admiral -, 68, 91.

Shadden, Thomas J., 205.

Shark (ship), 135 .

Shawnees (Indian tribe), 74 .

Sheep, 28.

Shepard, Cyrus (teacher), 55.
Ships, 33, 35, 36, 38, 45, 47, 48, $51,5^{8}, 59,61,63,68,103,105$, II3, I I $5,135,181,182,183,186$, 194, 195, 196, 222, 223, 258, 267.

Shortess petition, I04, I $16-119$, 148, 175-209, 210, 212, 253, 254. Shortess, Robert, I16, I19, 196, 204, 206, 208, 209, 2II, 255.

Simpson, Sir George, 90, 96, 270.

Sitka (Alaska), 29.

Skinner, A. A., 22.

Slacum,-, 202.

Slocum, W. A., 28.

Smith, A. D., 205.

Smith, Jedediah S. (furtrader), $33,35,36,38,74$.

Smith, Milton W., 209.

Snake country, 47.

Snake River, 27, 196.

Snelling, Vincent, letter to McLoughlin, 262-264.

Sonoma County (Cal.), 25.

Spalding, Mrs. Henry H., 54.

Spalding, Rev. Henry H., 54.

Spies, 91, 97.

Staats, Stephen, 82.

Stanstead (Canada), II2.

Stark, 一, 222.

Starrs,-, 222.

Statesman, cited, 262.

Stikeen (Fort), 24.

Stony Mountains, $175,176,178$, r8o (see Rocky Mountains).

Straits of Juan de Fuca, r93.

Sublette,-(furtrader), 33.

Sue, Eugene, 254.

Sumatra (a ship), 58.

Superior (lake), 24.

Surveyors, 224, 237, 251 .

Sutton, William C., I19, $205,2 \times 0$.

Sweet Water River, 185 .

TAXES, 67.

Teachers, missionaries as, 193.

Tennessee (state), 83 . 
The Dalles, $69,70,72,73,77$, 82, 9I, III, 197.

Thing, Captain -, 182

Thomas H. Perkins (American ship), 32, 194.

Thomas, Captain -, 36.

Thompson, L. S., 153.

Thornton, J. Quinn, 247, 248, 254; History of Provisional Government of Oregon, cited, 61, 62, 276,277 .

Thurston (county), 170.

Thurston, Samuel R., II9, I2I, I22, 123, 229, 230, 231, 233, 234, $237,238,239,241,242,243,244$, $245,246,256,261,262,263$; his letter, I23-140; protests against him, I37-r40; acts approved, I39; acts not endorsed, r4o; death, I44; career and death, 144-146; illtreats McLoughlin, I48, I49; false statements by, I52, I6I; excerpts from speech, 2 ro, 2 II, 246-256, $258,259,260$, $26 \mathrm{I}, 262$.

Timber, 201, 23j, 236 (see also Lumber).

Tolmie, Dr. F. W., 236.

Tongue Point (Ore.), 52.

Tonner, A., 205.

Tonquin (ship), 24, 285.

Town,-, 128.

Townsend, John K., Narrative of a Journey across the Rocky Mountains, cited, 49, 50.

Trade and commerce, 95, 191, 192. Trade licenses, 177, 178, 179, 180 . Traders, American, 33, 45-52, 81 . Trading act, $\mathbf{x 7 7}$.

Trading Companies, 95, 96, 176179 (see also Hudson's Bay Company, and Northwest Fur Company).

Trading posts, 27, 28.

Trappers, 191.

Treaties, 19, 20, 21, 39, 68, 86, 87,
128, 129, 131, 141, 142, 216, 253, 254 (see also Conventions).

Tualatin Plains, 203, 204, 210.

Turner, John, 205.

Turnham, Joel, 205.

Typhus fever, $285,286$.

UMPQUA, 184.

Umpqua River, $34,35,36$.

United States, I9, 20, 26, 28, 32, $33,38,39,64,65,66,67,68,7 \mathbf{r}$, $72,85,88,90,95$, roo, ror, ro4, I05, I11, I12, I1 $3,120,121,122$, $123,125,128,136,143,147,148$, 1 50, $151,156,157,159,164,175$, $176,177,178,179,184,185,186$, 189, 198, 201, 210, 215, 216, 220, 221, 225, 227, 232, 233, 235, 239, 240, 248, 250, 257, 260, 265, $266,267,274,280,282,286$.

United States Senate, ro4, ro5, II9, 120, 202, 260.

University of Oregon, II9, I4I, I 42, I 43, I $50,160,272,278$.

VANCOUVER Barracks, 28.

Vancouver (Fort), 24, 27-34, 35, $36,37,39,41,43,45,46,47,48$, $50,51,53,54,55,57,58,59,67$, $68,70,71,72,75,76,77,78,79$, $82,89,91,92,93,95,98,99$, I 10, $113,152,170_{2} 171,180,181,182$, $183,185,190,191,195,197,199$, 200, 201, 202, 204, 206, 208, 236, $253,255,257,258,268,275,276$, $28 \mathrm{r}, 285$.

Vancouver Island, 24.

Vancouver, Point, 28.

Varney, Captain -, 32.

Vavasour, Lieutenant and Captain -, 9r, 94, 270.

Venison, 43.

Victor, Frances Fuller, 226, 270; The River of the West, cited, 97, 110, 219, 227, 27 r.

Victoria (Queen of England), $13 \mathbf{r}$, $233,250,267$. 
Virginia (state), $8_{+}$.

\section{IVAILATPU (Wash.), 54 .}

Wait, Aaron E., 247, 248, 254.

Walahmette Valley, 78 (see Willamette Valley).

Walamet Valley, 269 (see Willamette Valley).

Walker,-, 55 .

Wallace,-, 222.

Wallamatte River, 266 (see Willamette River).

Wallamet Falls, I04, I63, 219 (see Willamette Falls).

Wallamette River, 108, I15, 224 (see Willamette River).

Wallamette Valley, 265, 28+ (see Willamette Valley).

Wallammette Falls Settlement, 213, 218 (see Oregon City).

Walla Walla (Wash.), 54, 77.

Waller, Rev. Alvin F., ro6, 107, I o8, I O9, I I O, I I I, I 14, I I 5, 1 27, I $91,205,212,213,214,215,216$, 2 I 7, 2 I 8, 21 9, 220, 223, 224, 225, $226,227,236,237$.

Wappatoo Island, 258.

Warehouses, 109, 202.

W'arre, Captain -, 91, 270.

Wars: $67,157,164$. American Revolution, 20, 83 ; War of 1812 , 20,84 ; Indian, $27,40,84,88$, $145,274,277$.

Washington, D. C. (city), 2I, 86, 104, I19, 123, I30, 150, 211,219 , $222,223,234,263,276$.

Washington (state), 19, 54, 170, 211.

Washougal (Wash.), 28.

Watt, Joseph, Recollections, cited, $79,281-283$.

Webster, Noah, 234.

Wesleyan Church, Ir2.

Wesleyan Missionary Society, 112, (see also Missionaries, and Missions).
Western Star, cited, I44, 262.

Vest, Middle, 84.

West Point (N. Y.), 227.

Westport (Mo.), 58.

Wheat, $28,4 \mathrm{r}, 42,46,49,80$, II 8 , I22, 200, 201, 202, $210,232,257$, $258,263,268,280$.

White, Dr. Elijah (medical missionary), 58, 97, 104, 118, 136, I $37,226,227$.

Whitman, Dr. Marcus, 53, 54, 60, $73,74,167,280$.

Whitman, Mrs. Marcus, 54.

Whitman massacre, 27, 40, 74 .

Wilbraham (Mass.), I12.

Wilkes,-, Journal, cited, 233.

Wilkes, Commodore Charles, 29, $266,267,268$; excerpts from his Narrative, I 9o-1 96.

Wilkes, George, History of Oregon, cited, 75 .

Willamette, I30, I3I, 205.

Willamette Falls, I06, III, II4, I1 7, 119, 136, 200, 202, 219, 235.

Willamette Milling and Trading Companies, $\mathrm{I}+1,1+2$.

Wrillamette River, 28, 49, 52, 75, 102, 107, 114, 136, 181, 182, 183, $185,186,192,193,199,200,230$, $233,236,258,286$.

Willamette Valley, $37,39,42,44$, $46,55,64,70,77,88,89$, 102, 103, I 16, 136, 140, I9I, 2 I 1, 232, 269.

William and Ann (ship), 35, 38 .

William (Fort), 24, 47 .

Williams, R., 205.

Willson, W. H., 205.

Wilson, Albert E., I 6 , 206, 208, 209, 2 II.

Wilson, E. C., 204.

Winthrop, Robert C., 144, 256, 258, 260.

Wrecks, 35, 45, 194, 196 (see also Ships).

Wyeth, Captain Nathaniel J., 32, 
$45,46,47,49,54,57, \mathbf{x} 7, \mathbf{x} 44$, x 81, х82, x 83, x96, x99; Journal cited, $45,46,47,48$; letters to, $256,257,260$; letters by, 257259, 260, $26 \mathrm{x}$.

Wygant, Mrs. Theodore, 25.

Wyoming (state), 20.
YAKIMA (Indians), 274.

Yatten, Joseph, 205.

Yerba Buena, 25, 69 (see San Francisco).

Young, Ewing, 50, 51, 52, 64, 204.

Young, Frederic G., 272, 279. 



\section{$\mathfrak{E} \mathfrak{a r l y}$ 2Mestern

A SERIES OF ANNOT ATED REPRINTS of some of the best and rarest contemporary volumes of Travel, descriptive of the Aborigines and Social and Economic Conditions in the Middle and Far West during the Period of Early American Settlement.

\section{COMPRISES THE FOLLOWING VOLUMES}

1-Weiser's Journal of a Tonr to the Obio in 1748. Croghan's Tours into the Western Country. 1750-1765. Post's Western Tours. 1758-59. Morris's Journal relative to his Thrilling Experiences on the Maumee in 1764.

2-Long's Voyages and Travels of an Indian Interpreter and Trader, 1768-1782.

3-Michaux (André) Travels into Kentucky in 1795. 96. Michaux (F. A.) Travels to the West of the Alleghanies, 1802. Harris's Tour into the Territory Northwest of the Alleg banies, 1803.

4-Cuming's Tour to the Western Country. etc. 1807-1809.

5-Bradbury's Travels in the Interior of America. 1809-1811.

6-Erackenridge's Voyage up the Missouri, 1811 Franchere's Voyage to the N. W. Coast, 1811$18 \mathrm{i4}$.

7-Ross's Adrentures of the First Settlers on the Oregon, 1810-13.

8-Buttrick's Voyages, Travels, and Discoveries. 1812-19. Evans's Tour of 4000 miles tbrougb Western States and Territories. 1813.

9-Flint's Letters from America, 1818-1820.

10-Hulme's Tour in the West (Ohio. Indiana, and Illinois), 1818. Flower's Letters from Lexington and Illinois, 1819. Flower's Letters from Illinois, 1820-1821. Woods's Residence in English Prairie, lllinoig, 1820-1821.
11, 12-Faux's Tour to the United States, 18191820. Welby's Visit to North America and Illinois, 1819-1820.

13-Nuttall's Trarels into Arkansas Territory. 1819.

14, 15, 16, 17-S. H. Long's Expedition from Pittsburg to the Rocky Mountains. 1819-1820

18-Pattie's Personal Narrative of Expedition from St. Louis to the Pacific, 18\%4-1827.

19,20-Ogden's Tour tbrough the Western Country. 1821-1823. Bullock's Journey through Western State8. 1827. Gregg's Commerce of the Prairies. 1831-1839.

21-Wyeth's Journey from Atlantic to Pacific, 1832. Townsend's Journey across the Rockies to Columbia River, 1834.

22, 23, 24, 25-Maximilian, Prince of WiedNeuwied's Travels in the Interior of Nortb America witb folio Atlas. 1843.

26, 27-Flagg's Fat West, 1836-1837. De Smet's Letters and Sketches. Residence among Indian Tribes, 1841-1842.

28, 29-Farnham's Travels in the Great Western Prairies, etc., 1839. De Smet's Oregon Missions and Travels, 1845-1846.

30-Palmer's Travels over the Rocky Mountains. $1845-1846$.

31-Index to the Series.

Edited with Historical, Geographical, Ethnological, and Bibliographical Notes, and Introductions and Index, by

Reuben Gold Thwaites, LL. D.

With facsimiles of the original title-pages, maps, portraits, views, etc. 31 volumes, large $8 \mathrm{vo}$, cloth, uncut, gilt tops. Price, $\$ 4$ net per volume (except the Atlas, which is $\$ 15 \mathrm{net}$ ).

\section{An Elaborate Analytical Index to the Whole}

Almost all the rare originals are unindexed. In the present reprint series, this immense mass of historical data will be made accessible through one exhaustive analytical index.

\section{EXTRACTS FROM A FEW OF THE REVIEWS}

AMERICAN HISTORICAL REVIEW: "The books are bandsomély bound and printed. The editing by Dr. Thwaites seems to have been done with his customary care and knowledge. There is no want of helpful annotations. The books therefore are likely to be of more real value than the early prints from which they are taken."

THE OUTLOOK: "Dr. Thwaites is the best possible editor who could bave been chosen for such a task."

"The student of society. as well as the historian, can profit by the perusal of these travels; . . they present, as is nowhere else so well presented, the picture of society in the making in the American back country."-Frederick J. TURNER in the Dial.

THE NATION: "Thorougbly interesting, as well as historically valuable." 


\title{
DOCUMENTARY HISTORY OF RECONSTRUCTION
}

\author{
Political, Military, Social, \\ Religious, Educational छூ Industrial \\ 1865 to the Present Time
}

\author{
SELECTED AND EDITED BY \\ WALTER L. FLEMING, Ph. D. \\ PROFESSOR OF HISTORY IN WEST VIRGINIA UNIVERSITY
}

Printed on a specially made paper, illustrated with facsimiles, two volumes, large 8vo, (about 900 pages), cloth, uncut, gilt tops. Price per set, $\$ 10.00$ net.

This work has been prepared in response to a demand on the part of students and thoughtful readers for an adequate collection of historical material which shall

1st. Present the original sources, which alone give the true contemporary conditions, and allow the reader to make his own interpretation of the facts.

2nd. Comprehend all phases of the progress and results of Reconstruction, social and economic, as well as political.

3rd. Exhibit not only the national aspects but also the local conditions of Reconstruction, in all the States.

Drofessor Fleming is recognized as one of the fore1 most authorities in the country on the Reconstruction Period. The excellence of his previous contributions on special topics in this field is sufficient guarantee of the value of the present comprehensive work.

"It is certainly a most interesting and important plan."-Woodrow WILSON.

"Every student . . . will rejoice over this addition to his facilities for intelligent appreciation of the great interests involved in the sectional struggle of 1861-1865, and its aftermath."-Chicago Evening Post.

"I feel sure that your work will be of great interest and benefit to the future historian." - Thomas Nelson PAGE.

Full descriptive circular and list of documents will be sent by the publishers on application. 


\section{Dr. JOHN MCLOUghLin}

\section{The Father of Oregon}

by

FREDERICK V. HOLMAN

Director Oregon Historical Society

Printed in large type on Dickinson's deckle-edged paper, with portraits, one volume, large suo., about 300 pages, cloth, mucut. Price, $\$ 2.50$ net.

R. JOHN McLOUGHLIN is fitly known throughout the Nortliwest as the Father of Oregon. A

Canadian of Scotch-Irish descent, he was yet a typical American pioneer and a lover of liberty. During the primitive days of joint occupation of the Oregon country with England, he showed himself a friendly and constructive statesman. His was the commanding personality in the history of the Pacific Coast during the second quarter of the last century.

HIS Although comparatively a young man, he was WORK sent ont by the Hudson's Bay Company to become the chief factor of that great monopoly in the far western wilderness, beyond the Rocky nowitains. A ninn of action, whose ideal was Napoleon, yet just and humane, he soon became the absolute ruler of the Pacific coast from San Firancisco to Alaska. For a score of years he retained this commanding position, the hope and support of all Oregon pioneers, king of a thousand Canadians, autocrat of a hundred thousand Indians. He laid the cornerstone of the State of Oregon and the Pacific Northwest.

HIS IMPOR'TANCE are essential parts of the history of the Oregon comntry, Dr. John McLoughlin stands supremely first. Writers on the early setilement of that region make frequent mention of his name and dwell generonsly on his achievemnts. Altho dead a half-century it is only within the last few 
years that his work has come to be duly appreciated, monuments erected in his honor and memorials of learning raised in his remembrance. The political strife and religious bigotry which cast a clond over his latter days have passed away, and he stands out today in bold relief, as the first man in the history of Oregon and the Pacific Northwest. He was truly one of the noblest men who ever gave a life of labor in the spread of American civilization.

"A character worthy of perpetual commemoration and admiration, illuminating by humanity and Christian doctrine, the dark chapter of wilderness life from the Atlantic-to the Pacific." -H. S. Lyman, in his "History of Oregon."

"He was a born leader of men; the most humane and successful manager of the native tribes this country has ever known."-Hon. Willard H. Reese.

"He was respected by all as a courageous and honorable man. As a churchman he was devoted to the creeds and mode of worship of the Catholic Church, living and dying in its faith." -The Morning Oregonian, Nay 2, 1907.

"No man ever lived in the Northwest is so much entitled to have his memory suitably commemorated as Dr. McLoughlin. He was the friend of the early pioneer and was loved and honored by them all."-Hon. Geo. A. Chanberlain, Governor of Oregon.

"Dr. McLoughlin was by far the most commanding figure in the early history of the Pacific Northwest. It was due to his generosity that the early American settlers did not perish miserably from hunger, and it was due to his strong administration that they were not slaughtered by the Indians; a deeply rooted religions belief prompted ererv act of his nohle life." - The Most kev. Alevander Christie, D.D.. Archbishop of Oregon.

"He was the greatest benefactor the State of Oregon has ever had, a man whose statue should be in the Hall of Fane at Washington." - Rev. A. Hillebrand.

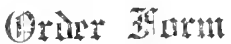

THe Artitr I'. Ciark Compant, Publishers.

Cleifhand, OHHO.

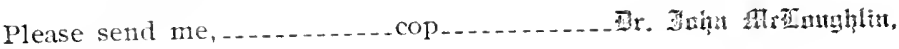
price $\$ 2.50$ net.*

Name.

Address 190

*If to be sent by mail, or prepaid express, add 20 cents. 





:

$\checkmark$ 